\title{
ARAÇÁ AZUL: UMA ANÁLISE SEMIÓTICA
}

\author{
Dissertação apresentada à Área de Semiótica e \\ Lingüística geral do Departamento de Lingüística \\ da Faculdade de Filosofia, Letras e Ciências \\ Humanas da Universidade de São Paulo para a \\ obtenção do título de Mestre.
}

Orientador:

PROF. DR. LUIZ AUGUSTO DE MORAES TATIT

SÃo PAULO 
Para Carina,

pelo infalível e incondicional apoio, pelas inúmeras contribuições a este trabalho, por ter me apresentado a genialidade e a graça da cultura baiana, pela inspiração de toda uma vida. 


\section{AGRADECIMENTOS}

Aos mestres Luiz Tatit e Ulisses Rocha, pessoas abençoadas com raro talento e dotadas de imensa capacidade de transmitir o vasto e profundo conhecimento que possuem.

Ao professor José Roberto Zan, por ter despertado em mim o interesse pela pesquisa, e pela idéia original de estudar o LP Araçá Azul.

Aos professores José Luiz Fiorin, Diana Luz Pessoa de Barros, José Miguel Wisnik, Dilma de Melo Silva, Ivã Carlos Lopes e Antonio Vicente Seraphim Pietroforte, peças fundamentais na elaboração deste trabalho.

Aos professores Mozart Melo, Mara Leporace, Sérgio e Sidney Molina, Fernando de la Rua, Alexandre Zilahi, Gogô, Ciro Pereira, Eduardo Goldemberg, Fernando Faro, Claudiney Carrasco, Eduardo Andrade, Paulo Justi e todos aqueles que me acompanharam na aventura do saber.

À D. Edith e seu neto Ninho, pelas valiosas informações prestadas, e à Renata Lordelo por estabelecer este contato.

À minha família, em especial Sonia Machado de Campos Dietrich, Carl Peter Von Dietrich e Helena Nader, todos grandes pesquisadores, pelo apoio constante.

Finalmente, à minha mulher Carina e meus filhos Pedro e Luíza, pelo fornecimento contínuo de amor e motivação. 


\section{UNIERSUDADE DESTO PAULO

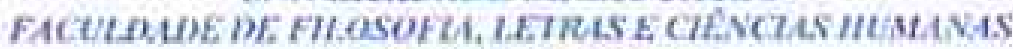 \\ Somipo de Flis-Giraderayio}

\section{AIA DE DEFESA DE MESTRADO}

Em is de outubro de 2003, na Sata de Defesas desta Faculdade, realičou-se a detesa da Dissertaçầo de Mestrodo de Peler Dietrich intituloda: "Araçá Axul: uma anólise semb́lica' para obtençoo do Titulo de Mestre em Lingalstíca: Serniólica e Lingöistica Geral. Após decilarada aberta a sessao, o Sr, Presidente deu a palavra dos examinadores para as devidas argutiçes que so desarivolveram no: femos regimentais. En seguida, a Comissa Examinadora. om sessìa secrota, passeu aos trabalhos de julgamento. decidindo, par unanimidade, aprovar o cancfiato.

À vista deste resultado, Pelet Dletrich fol considerado aprovado com distinçao e louvor. Iazendo jus ao Titulo de Mestre em lingalstica: Serniotica 6 Lingülsfica Geral.

A banca recomenda a publcaça do frabalho o manifestase foveravoimente a que o fexto defencfido seja incorporado ao banco da Biblioleca Digital da Universidado de Sao Paulo.

Para constat, Regina Celi Sant'Ano, Chele Administrativa do Servko de Pós-Graduaçoo, redigiu a presente Ata, que vai assinada pelos Senhores membros da Combsó Examinadora. Sco Pauto, aos is de outubro de 2003.

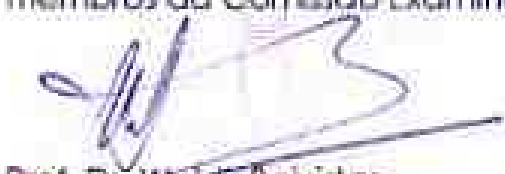

Prot. Oreweidr Betvidas
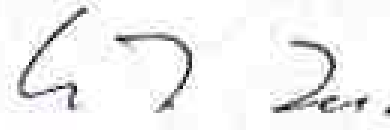

Prot. Dr. Celso Fernando Favaretito

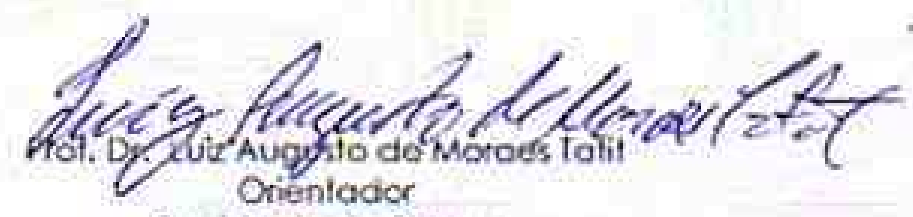

Presidente da Banca

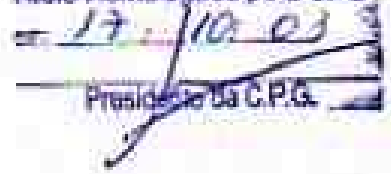




\section{RESUMO}

Lançado no Brasil em 1973, o LP Araçá Azul é considerado a mais radical experiência tropicalista já realizada. Ela é obra do cantor e compositor baiano Caetano Veloso, um dos maiores e mais fecundos pensadores da cultura brasileira, que na época do lançamento deste LP já gozava de enorme prestígio junto ao público local, principalmente devido ao enorme sucesso da canção "Alegria, alegria". Este disco é o primeiro a ser lançado depois do retorno do exílio do compositor em Londres imposto pela ditadura militar. Essa combinação de fatores faz do Araçá Azul uma obra sui generis na história da música popular. No entanto, não havia até agora nenhum estudo concentrado neste LP.

O objetivo desta dissertação é analisar minuciosamente todos os elementos presentes no álbum, não só as canções e faixas experimentais mas também todo o projeto visual, que inclui capa, contracapa e encartes, evidenciando assim as estratégias utilizadas para a construção do sentido na obra. O método descritivo escolhido foi a teoria semiótica, iniciada por Greimas e ampliada por Fontanille e Zilberberg, e seu desdobramento no campo da canção popular na acepção de Luiz Tatit.

Além de resgatar um importante acontecimento na história da música brasileira, este trabalho também contribui para a discussão do modelo descritivo adotado, apontando suas limitações atuais e sugerindo novas frentes de pesquisa para a ampliação de seu horizonte teórico.

Palavras-chave: semiótica, música, canção, tropicalismo 


\begin{abstract}
Edited in Brazil in 1973, the LP Araçá Azul is considered to be the most radical tropicalist experience ever produced. It was created by Caetano Veloso, a composer, singer and one of the most prolific Brazilian thinkers. At that time, he was already recognized as a Pop-Star by the local public, due to the great success of his song "Alegria, Alegria". This was the first record edited by the composer after returning from his political exile in London, which was imposed by the military regime. This combination of events makes Araçá Azul a "sui generis" piece in the history of popular music. Nevertheless, up to the present time no study of this LP has appeared in the literature.

The objective of this dissertation is to analyze in detail all the elements of the album, not only the songs and experimental tracks, but also the visual project as a whole, including the front, back and inner covers. The purpose is to show all the strategies used to construct the signification of the album. The descriptive method adopted is the Semiotic Theory, initiated by Greimas, and further developed by Fontanille and Zilberberg, and extended to the field of popular music, as postulated by Luiz Tatit.

The present work not only unveils an important event in Brazilian musical history, but also contributes to the discussion of the descriptive model adopted, pointing out its limitations and suggesting new lines of research to broaden its theoretical horizons.
\end{abstract}

Key words: semiotics, music, song, tropicalism 


\section{Métodos}

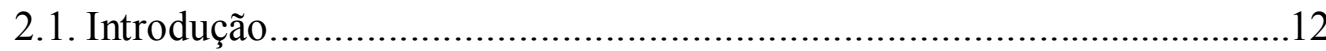

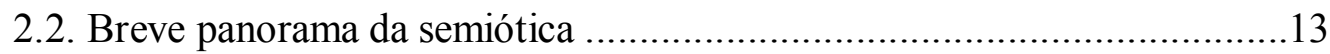

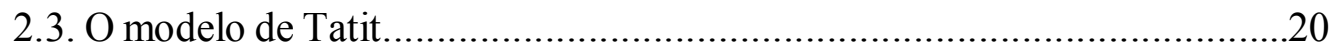

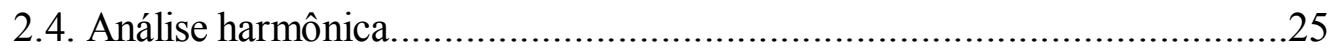

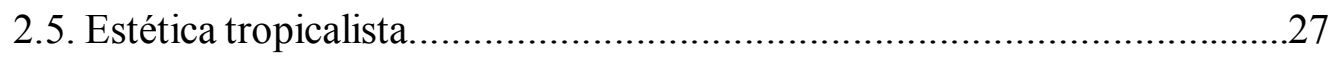

\section{Projeto Visual}

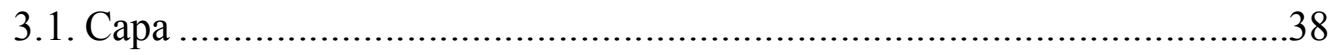

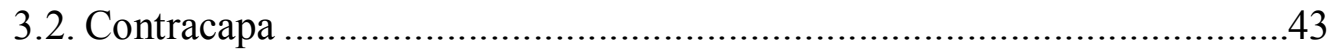

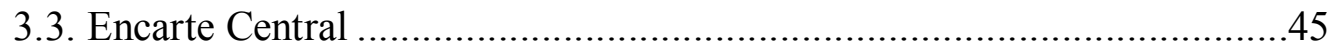

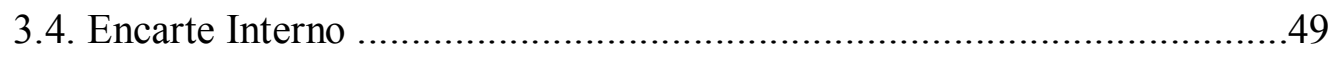

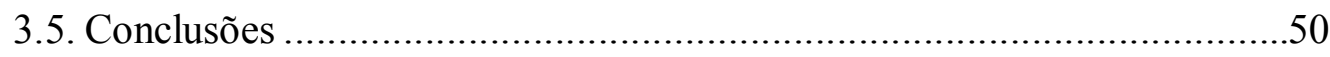

\section{Projeto Musical}

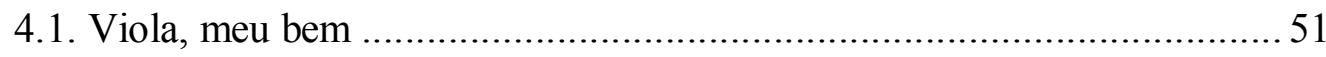

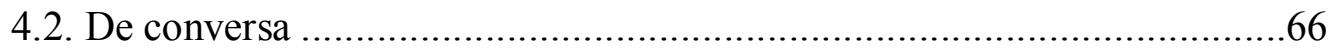

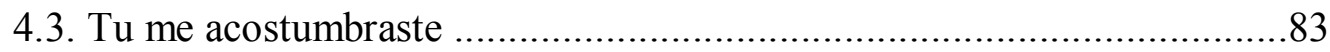

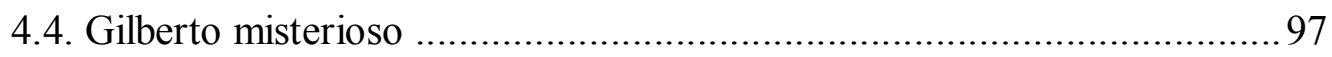

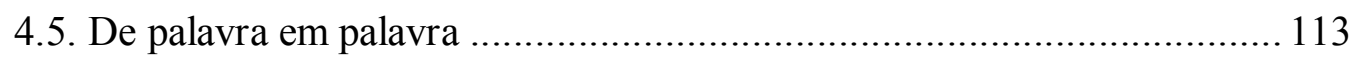

4.6. De cara / Quero essa mulher assim mesmo ...................................... 121

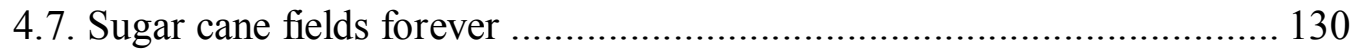

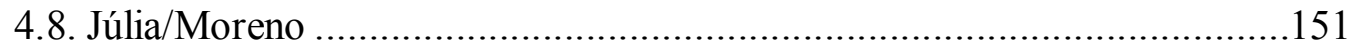

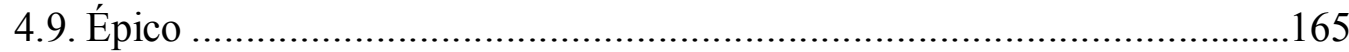

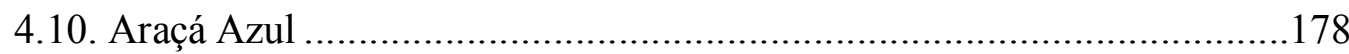

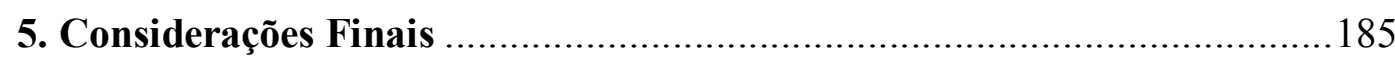

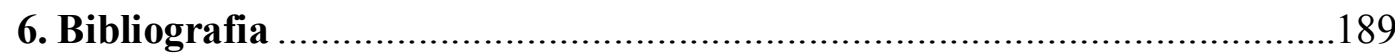

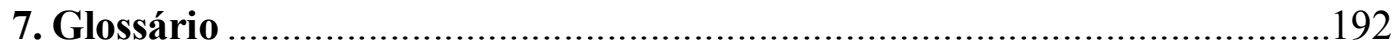

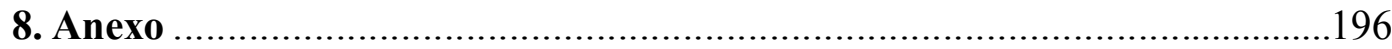




\section{Introdução}

Mais de trinta anos após a explosão do movimento, ainda estamos no meio do processo de compreensão do que representou e, mais importante ainda, do que representa hoje o tropicalismo. O tropicalismo vem sendo revisitado e revisto em diversas publicações, entre elas o pioneiro Tropicália, alegoria, alegria, de Celso Favaretto (1979); Verdade Tropical, do próprio Caetano (1997); Tropicália, de Carlos Calado (1997); além do álbum Tropicália 25 anos, de Caetano e Gil. No entanto, embora citações apareçam, nenhuma dessas obras se propôs ao estudo da mais radical experiência tropicalista, o Araçá Azul.

Toda manifestação tropicalista girava em torno das canções de Caetano e de Gil, e até mesmo o álbum-manifesto Tropicália é um álbum de canções. Todas as expectativas em torno do Araçá Azul indagavam qual seria o teor das novas canções. Lançado em janeiro de 1973, este surge como a anti-canção, o avesso do avesso do avesso da canção. Ele não foi o único disco experimental brasileiro da época, mas seguramente foi o mais ouvido, e o que mais repercutiu. Enquanto a maioria dos trabalhos experimentais é produzida e apreciada por uma restrita elite da música erudita, o Araçá Azul é obra de um artista extremamente popular, que sempre trabalhou no âmbito da música popular.

Este LP é, ao menos em parte, a realização tardia do projeto que Caetano tinha antes do exílio. Nele estão presentes elementos de várias tendências das artes de vanguarda, sincretizadas com outras fontes: da antropofagia de Oswald de Andrade ao Concretismo dos poetas paulistas, do samba de roda ao Microtonalismo de Walter Smetak, passando pelo bolero e rock'n'roll. Toda informação estética e sonora que passou pelo Brasil foi aproveitada como matéria-prima para a composição do disco. $\mathrm{O}$ 
objetivo principal desta dissertação é descrever e analisar minuciosamente todos os elementos que compõem o álbum Araçá Azul, incluindo todo o material sonoro e visual, evidenciando assim as estratégias empregadas na construção do sentido da obra.

O ponto de partida para a consolidação do corpus do presente trabalho decorre da hipótese de que o objeto a ser estudado, o LP Araçá Azul, não se limita ao material sonoro. Assim como o LP Tropicália, panis et circenses, lançado em 1969, capa, contracapa e encartes fazem parte, junto com o material sonoro, de um projeto único. Esses elementos não poderiam ser omitidos de uma análise que se propõe estudar a obra como um todo. Os esforços analíticos foram então divididos em projeto visual, composto pela capa, contracapa e encartes, e projeto sonoro, composto pelas dez faixas do LP. Cópias digitalizadas e reduzidas do material visual original foram anexadas ao final do texto.

O projeto sonoro alterna canções de estrutura tradicional e faixas experimentais compostas a partir de vozes, ruídos e sobreposições de outras canções. A análise coerente de um material tão diverso só poderia ser eficaz se fosse contemplada por um modelo descritivo único, que desse conta ao mesmo tempo da diversidade e da especificidade de cada elemento. É por essa razão que adotamos a semiótica greimasiana como modelo central da análise. Dotada de imensa flexibilidade, essa teoria ainda em desenvolvimento consegue descrever os mecanismos gerais da significação, respeitando a especificidade de cada objeto. Inicialmente apresentada como instrumento de análise do discurso lingüístico, seu leque de ferramentas está em constante expansão, graças à contribuição contínua de novos estudos e pesquisas. Dentre elas destacamos a teoria desenvolvida por Luiz Tatit, cujo foco de atenção é justamente a canção popular. 
Um dos grandes problemas encontrados ao trabalhar em uma área fronteiriça de dois campos do saber - no nosso caso a música e a lingüística - é encontrar um meio de produzir um texto que possa ser apreendido por leitores oriundos das duas áreas. O principal obstáculo encontrado nesta tarefa é o da linguagem: cada área possui um conjunto de termos próprios e, muitas vezes, termos absolutamente triviais em determinado campo podem representar verdadeiro desafio à compreensão em outro. Pior ainda: podem induzir interpretações completamente equivocadas.

Para tentar minimizar o problema e não restringir de antemão o leque de possíveis leitores deste trabalho, optamos por realizar descrições mais detalhadas dos procedimentos específicos na apresentação dos métodos. Não obstante, incluímos no corpo do trabalho notas explicativas na primeira aparição de cada termo técnico passível de dúvida. Finalmente, apresentamos no final do trabalho um pequeno glossário de termos musicais. Para o apoio de leitores que não têm familiaridade com a teoria semiótica, recomendamos as obras "Elementos de análise do discurso", de José Luiz Fiorin, e "Teoria semiótica do Texto", de Diana Barros, esta última contendo também um valioso "vocabulário crítico" que descreve sucintamente o significado dos principais termos empregados pela semiótica. A obra de referência para o estudo do modelo de Luiz Tatit é "Semiótica da canção". O método de análise harmônica empregado seguiu a sistematização dada por Almir Chediak em "Harmonia \& Improvisação". Todas essas obras encontram-se listadas nas nossas referências bibliográficas.

Apesar da força de coesão que faz com que o LP seja percebido como uma unidade, respeitamos a autonomia das faixas na descrição e análise do material auditivo, fato que orientou a organização do nosso texto. Nossa análise segue então o roteiro sugerido pelo autor na escolha da seqüência das faixas, a exemplo do processo 
de audição natural do disco. Após a análise de cada faixa, os dados obtidos serão imediatamente convocados para o diálogo com o material já apurado. Nas considerações finais, apresentamos uma rápida visão panorâmica dos resultados mais significativos, assim como algumas proposições para o desdobramento deste trabalho. 


\section{Métodos}

\subsection{Introdução}

O maior problema enfrentado por pesquisadores que se dedicam ao estudo da canção é a dificuldade de encontrar um procedimento metodológico que dê conta de analisar, de maneira consistente e integrada, seus elementos constituintes: letra e música (que ainda poderia ser fracionada em ritmo, melodia, harmonia e arranjo). A solução mais adotada é a de focalizar o estudo em um dos elementos (letra ou música) e menosprezar (ou simplesmente descartar) o outro. Encontramos, infelizmente com demasiada freqüência, estudos (acadêmicos e não acadêmicos) que ora tomam a canção como uma "poesia musicada", ora como "tema musical com letra". Esses estudos emprestam modelos que provêm da análise literária e da análise musical, respectivamente, eficientes para o estudo dos elementos individuais, mas que não dão conta do todo. No entanto, é exatamente na interação entre o texto lingüístico e o texto melódico que a canção constrói o seu sentido.

Ela [a canção] remete a diferentes códigos e, ao mesmo tempo, apresenta uma unidade que os ultrapassa: como não é um poema musicado, o texto não pode ser examinado em si, independentemente da melodia - se isso for feito, pode-se ter, quando muito, uma análise temática. A música, por sua vez, é refratária a uma análise de tipo lingüístico, pois a melodia não apresenta unidades significativas, semânticas. Além disso, a canção comporta o arranjo, o ritmo e a interpretação vocal, que se inserem em gêneros, estilos e modas, dificultando a definição de uma unidade ${ }^{1}$

A única maneira de analisar corretamente uma canção é considerá-la um texto sincrético, em que o sentido é construído por um componente lingüístico, um componente musical, e a interação de ambos. 


\subsection{Breve panorama da semiótica}

Influenciado por um lado pela obra de F. Saussure e L. Hjelmslev, e por outro pela teoria de V. Propp, A. J. Greimas propõe em seu Sémantique structurale ${ }^{2}$ um sistema de análise que pretende desvendar a sintaxe que ao mesmo tempo organiza e constrói o sentido dos textos. Esse foi o ponto de partida da semiótica greimasiana.

O objeto de estudo da semiótica é muito mais amplo do que possa parecer à primeira vista. $\mathrm{O}$ conceito de texto tem aqui desdobramentos normalmente não abarcados pela acepção do senso comum. Ele pode ser tanto um texto lingüístico, escrito ou falado, como também um texto visual (uma pintura), auditivo (uma sonata), gestual (uma coreografia), plástico (uma escultura) ou até mesmo gustativo (uma iguaria). Ele pode ser também uma combinação de vários textos diferentes: um filme, um livro ilustrado, uma canção. Para que a análise possa dar conta desses textos sincréticos, ela necessita de ferramentas que não apenas examinem as especificidades de cada forma de expressão, mas também estabeleçam relações entre elas dentro de um mesmo campo teórico. Ela precisa ainda compreender o texto não só como um objeto de significação, que forma um todo coeso graças às suas estruturas internas, mas também como um objeto de comunicação, que estabelece relações com outros textos. Esse é exatamente o amplo e ambicioso projeto descritivo iniciado por Greimas. Aos seus esforços, somam-se as contribuições de seus discípulos dentre os quais destacamos Jacques Fontanille e Claude Zilberberg.

\footnotetext{
${ }^{1}$ FAVARETTO, Celso. Tropicália: alegoria, alegria. 2 ed. rev. São Paulo: Ateliê Editorial, 1996. pp. 28-29.

${ }^{2}$ GREIMAS, Algirdas Julien. Sémantique structurale. Paris: Larousse, 1966.
} 
A semiótica greimasiana propõe que o sentido de um texto é construído por um percurso gerativo, dividido em três níveis - fundamental, narrativo e discursivo, indo do mais simples e abstrato ao mais complexo e concreto. Ela estabelece uma sintaxe e semântica próprias para a análise em cada um desses níveis, que têm portanto uma estrutura autônoma, e descreve as relações que cada nível estabelece com os demais.

No nível fundamental, articula-se uma categoria semântica mínima, a partir da qual o sentido do texto é construído. São oposições de termos gerais e abstratos, como /vida/ vs /morte/ ou /natureza/ vs /civilização/, mas que possuem ao menos um traço em comum entre si. Esses termos mantêm uma relação de contrariedade, estando em relação de pressuposição recíproca. Aplicando-se uma relação de negação sobre cada um desses termos, obtemos uma relação de contradição, gerando os termos contraditórios (ex: /não vida/ vs /não morte/), contrários entre si. Esses termos são denominados subcontrários. Além dessas duas relações, a articulação de uma categoria semântica ainda prevê relações de implicação, pois os subcontrários implicam nos termos contrários (ex: /não vida/ implica /morte/). A união dos termos contrários produz o termo complexo (/vida/ e /morte/), enquanto a união dos subcontrários gera o termo neutro (/não vida/ e /não morte/). Todos esses elementos podem ser visualizados no quadrado semiótico, apresentado na figura1. Neste nível analisa-se não só a articulação da categoria, mas também sua movimentação, implicando uma direcionalidade (ex: afirmação de /vida/, negação de /vida/, afirmação de /morte/). Ainda no nível fundamental é feita também a aplicação da categoria /euforia/ vs /disforia/ sobre a categoria articulada, o que permite a inserção dos elementos semânticos numa axiologia, determinando valores positivos e negativos, desejados, proibidos, devidos ou temidos por uma comunidade. 


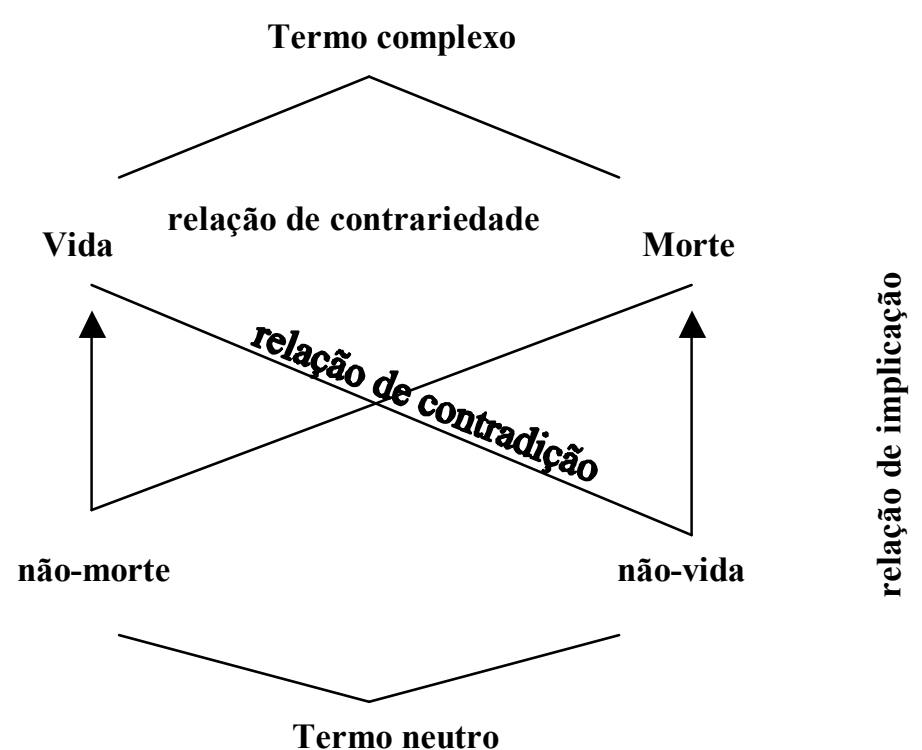

Figura 1

No nível narrativo, o percurso fundamental se manifesta sob a forma de transformações operadas por sujeitos. É no nível narrativo que se evidencia a relação de transitividade entre o homem e as coisas (dando origem aos papéis actanciais de sujeito e objeto), e a relação entre os homens (que dá origem aos papéis de destinador e destinatário). Aqui as relações podem ser conjuntivas ou disjuntivas, no primeiro caso, contratuais ou polêmicas no segundo. A narrativa se organiza então em enunciados (de estado ou de fazer), programas (de doação de competência semântica ou modal, de performance, de interpretação ou retribuição), percursos (do destinadormanipulador, do sujeito e do destinador-julgador), para formar o esquema narrativo.

O destinador-manipulador é o doador dos valores da narrativa. É ele quem instaura o objeto e o sujeito, transmitindo a esse os valores modais necessários para sua junção com o objeto (o /dever/ e o /querer/, modalidades virtualizantes). Essa manipulação é um contrato fiduciário: para que se realize, o sujeito deve antes de tudo crer nos valores representados pelo destinador. Se o destinador exerce um fazer persuasivo sobre o sujeito, este exerce um fazer interpretativo sobre aquele. Deste 
fazer decorre a aceitação (relação contratual) ou o rompimento (relação polêmica) do contrato proposto. Para realizar o seu fazer interpretativo, o sujeito lança mão das modalidades veridictórias, /ser/ (imanência) e /parecer/ (manifestação), que se articulam em verdade, falsidade, segredo e mentira (figura 2$)^{3}$.

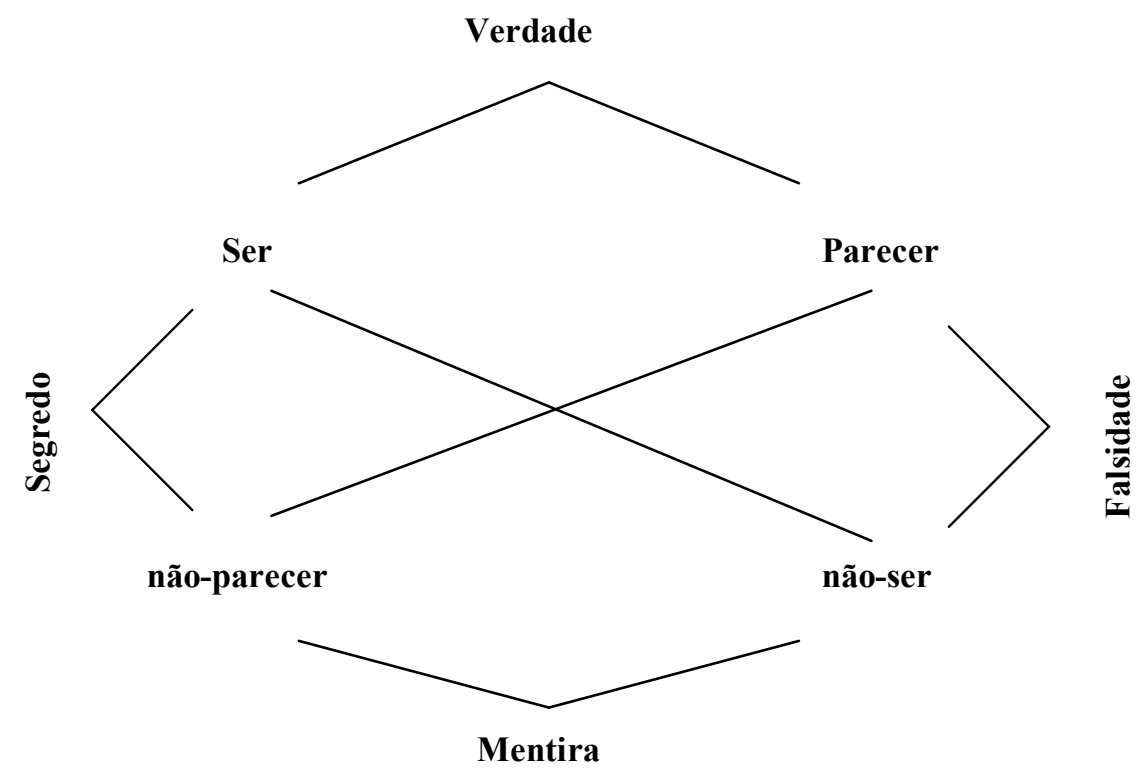

Figura 2

A manipulação pode assumir quatro formas principais: a tentação, a intimidação, a provocação e a sedução, definidas tanto pela competência do destinador (dotado do /poder/ ou do /saber/ sobre o sujeito) quanto pela modalidade transmitida ao sujeito (/querer/ ou /dever/). ${ }^{4}$ É interessante notar que vários destinadores podem concorrer na manipulação do sujeito. Desta forma, podem-se estruturar complexas configurações modais: /querer/ e /dever/, /não-querer/ e /dever/, /não-dever/ e /querer/, etc...

O percurso do sujeito descreve não só a realização de uma performance (a aquisição de um valor, por exemplo), como também sua trajetória na aquisição de

\footnotetext{
${ }^{3}$ BARROS, Diana Luz Pessoa de. Teoria semiótica do texto. São Paulo: Ática, 1997. p. 45.
} 
competência modal (representada pelo /poder/ e /saber/, modalidades atualizantes), suficiente para a realização da mesma. Ele é então composto pelo encadeamento lógico dos programas de competência e performance. A partir da obra "A semiótica das paixões", do modelo ao aprofundar a discussão sobre a modalização do ser. Os estados passionais são descritos a partir de configurações em que incidem as quatro modalidades principais, além das modalidades veridictórias, que se organizam em percursos. Temos então sujeitos dotados de modalizações complexas, tais como /crerdever-ser/ ou /saber-não-poder-ser/. O modelo ganha então a possibilidade de descrever paixões como o resultado de um percurso passional, e as performances relacionadas a estados passionais (como por exemplo a revolta, a vingança).

É no percurso do destinador-julgador que acontece a avaliação do estado do sujeito. No primeiro programa narrativo deste percurso, a sanção cognitiva, temos mais uma vez um fazer interpretativo, no qual são acionadas as modalidades veridictórias. O segundo percurso é o da sanção pragmática, que pode se desdobrar em duas possibilidades: no caso de uma sanção positiva, o sujeito pode receber uma recompensa pela sua performance; no caso de uma sanção negativa, recebe uma punição.

No nível discursivo, estuda-se a projeção da enunciação no discurso, as debreagens (enuncivas ou enunciativas), as embreagens, as categorias de pessoa, tempo e espaço, as técnicas de aproximação ou distanciamento, os recursos de ancoragem actancial, espacial e temporal, as relações argumentativas entre enunciador

\footnotetext{
${ }^{4}$ Ibid. p. 33.

${ }^{5}$ GREIMAS, Algirdas Julien; FONTANILLE, Jacques Semiótica das paixões. São Paulo: Ática, 1994.
} 
e enunciatário. É também no nível discursivo que os valores da narrativa dão origem aos percursos temáticos e aos investimentos figurativos.

Graças às marcas que a enunciação deixa no discurso, aquela pode estabelecer com este relações de aproximação ou de afastamento, que correspondem aos efeitos de sentido de subjetividade e objetividade, respectivamente. São várias as estratégias à disposição do enunciador para a realização deste simulacro. Ao instaurar uma primeira pessoa no discurso (debreagem enunciativa), o enunciador cria a ilusão da presença de alguém que fala. Por outro lado, a instauração de uma terceira pessoa (debreagem enunciva) afasta a enunciação do discurso, criando uma ilusão de neutralidade, promovendo no discurso o efeito de sentido de verdade objetiva. Outra importante estratégia para a construção do efeito de realidade no discurso é a ancoragem, recurso pelo qual o enunciador liga elementos textuais a seus referentes externos, como locais, nomes e datas. Da mesma maneira, o enunciador pode usar esses mesmos recursos para atestar a falsidade do seu discurso: tudo depende da estratégia de persuasão adotada.

Os valores manifestados no nível narrativo se organizam no nível discursivo em percursos temáticos, que podem ou não ser recobertos por percursos figurativos. Esses percursos não só garantem a coerência do texto, como também manifestam mais claramente suas intenções e propósitos. Muitas vezes, o sentido de um texto é dado pela relação entre vários percursos temáticos simultâneos, que se manifestam sobre a forma de isotopias temáticas e figurativas. Os elementos denominados conectores e desencadeadores de isotopias são as marcas que caracterizam os textos pluriisotópicos, e que permitem a leitura do mesmo a partir de um novo ângulo.

As ferramentas disponíveis para a análise em cada um dos níveis vêm se enriquecendo continuamente em trabalhos realizados pelos pesquisadores que se 
dedicam ao desenvolvimento do modelo proposto por Greimas. Não obstante, as pesquisas não se limitam ao percurso gerativo, mas abarcam também as relações que se dão aquém e além do mesmo. No primeiro campo, temos estudos que investigam as precondições do sentido, e seus reflexos nos diversos níveis da teoria. No segundo campo enquadram-se os estudos que investigam as relações entre o percurso gerativo e as manifestações textuais, imprescindíveis para a análise de textos poéticos, por exemplo. Paralelamente, existe um constante esforço de adaptar a teoria às semióticas específicas, como a semiótica visual ou musical.

A análise semiótica recebeu um grande impulso com a produção de um dos discípulos de Greimas, Claude Zilberberg. Ao aprofundar o estudo das categorias temporais, Zilberberg abre uma nova perspectiva para o modelo, oferecendo rico instrumental para a análise não só de textos lingüísticos, mas principalmente para textos que, como a música, trabalham preponderantemente com oposições tensivas que se desenvolvem no tempo. Zilberberg propõe cinco níveis no seu percurso gerador do sentido (tensivo, aspectual, modal, narrativo e discursivo), e opera em todos os níveis a oposição entre termos intensos e extensos. O primeiro se refere à concentração de tensividade, ruptura, saliência, parada. O segundo termo remete à expansão de tensividade, desdobramento, continuidade. O emprego desses termos em todos os níveis permite a articulação dos conceitos de temporalidade e espacialidade desde os níveis mais profundos do percurso, pois a oposição intenso vs extenso se aplica diretamente ao estudo do tempo (instante vs duração) e espaço (delimitação vs expansão). Essa proposta possibilita uma nova perspectiva na aplicação da teoria no texto musical, que trabalha diretamente com o tempo (por meio de recortes, com pulsações rápidas e repetições de temas, ou prolongamentos, com notas longas e desdobramentos) e espaço (restringindo-o ou ampliando-o, por meio da redução ou 
ampliação da tessitura). A oposição entre intenso e extenso nos diversos níveis permite a definição teórica de todos os procedimentos musicais de composição e arranjo.

\subsection{O modelo de Tatit}

Graças ao desenvolvimento das pesquisas de Luiz Tatit, a semiótica possui hoje ferramentas suficientes para, utilizando os mesmos princípios teóricos, analisar eficientemente letra e melodia, e a interação entre as duas. O modelo está descrito em seu Semiótica da Canção. ${ }^{6}$

A partir dessa teoria, Luiz Tatit vem propondo uma análise da canção que identifica a estreita ligação entre fala e canção, evidenciando os diversos níveis de relações existentes entre letra e melodia. Dessa maneira é possível perceber como se dá a construção do sentido numa obra que usa dois sistemas de significação distintos: um texto lingüístico sustentado por um texto melódico.

Assim como a canção, a fala é constituída por um texto lingüístico que se apóia sobre uma cadeia fônica. A diferença básica entre as duas formas de expressão advém do fato de que na fala, assim que a informação é transmitida, a cadeia fônica é automaticamente descartada e esquecida. Isso acontece porque os sons da fala não são estruturados dentro de um sistema organizado de alturas, mas apenas desenham um perfil que tem a finalidade única de linearizar o que está sendo dito. Ela é regida pela instabilidade. Já o perfil melódico da canção é precisamente definido dentro de um sistema musical. Estabelecer uma melodia dentro desse sistema é a estratégia utilizada

\footnotetext{
${ }^{6}$ TATIT, Luiz Augusto de Moraes. Semiótica da canção - melodia e letra. São Paulo: Escuta, 1994.
} 
para garantir a perenidade da composição. Desta maneira, a canção utiliza o eixo organizado pelo sistema musical para ganhar estabilidade.

Tatit descreve dois tipos de investimentos dentro desse sistema. $\mathrm{O}$ primeiro, resultado de um processo geral de aceleração, tem como foco principal o campo das durações. A reação natural à rápida repetição do pulso em um andamento mais acelerado é o surgimento de motivos rítmico-melódicos repetidos. A recorrência destes motivos ativa a memória, reduzindo o fluxo de informações, o que estabiliza o pulso rápido, evitando a sua dissolução. Esse processo recebe o nome de tematização. O segundo investimento é regido pela desaceleração, e tem como foco principal o campo das alturas. O pulso desacelerado tem como principal conseqüência o aumento da duração das notas, valorizando o contorno do perfil melódico e ampliando a tessitura. Esse é um terreno propício para a proliferação de grandes saltos intervalares e o prolongamento das vogais - fenômeno que recebe o nome de passionalização.

O pesquisador prevê também a possibilidade de infiltração de elementos desestabilizadores, que se opõem ao investimento na estruturação musical. Esse processo evidencia a fala que está por trás da voz que canta, ou seja, promove um retorno à instabilidade do discurso oral: trata-se da figurativização. Evidentemente, esses procedimentos não são mutuamente exclusivos. Eles podem aparecer combinados em proporções diversas. Uma canção pode escolher a tematização como projeto entoativo principal e apresentar passionalização residual. Ou então pode escolher um procedimento principal para a primeira parte e outro para a segunda. A articulação desses elementos no quadrado semiótico pode ser observada na figura 3.

A tematização e a passionalização podem ser entendidos como projetos entoativos de concentração e extensão, respectivamente. No primeiro caso, surgem os mecanismos de involução (tematização e refrão) e evolução (desdobramento e 
segunda parte). No segundo, os movimentos conjuntos (graus imediatos e gradação) e disjuntos (salto intervalar e transposição). Além de aplicar-se diretamente à análise das canções, a teoria se aplica também a qualquer melodia incidente fora do contexto canção.

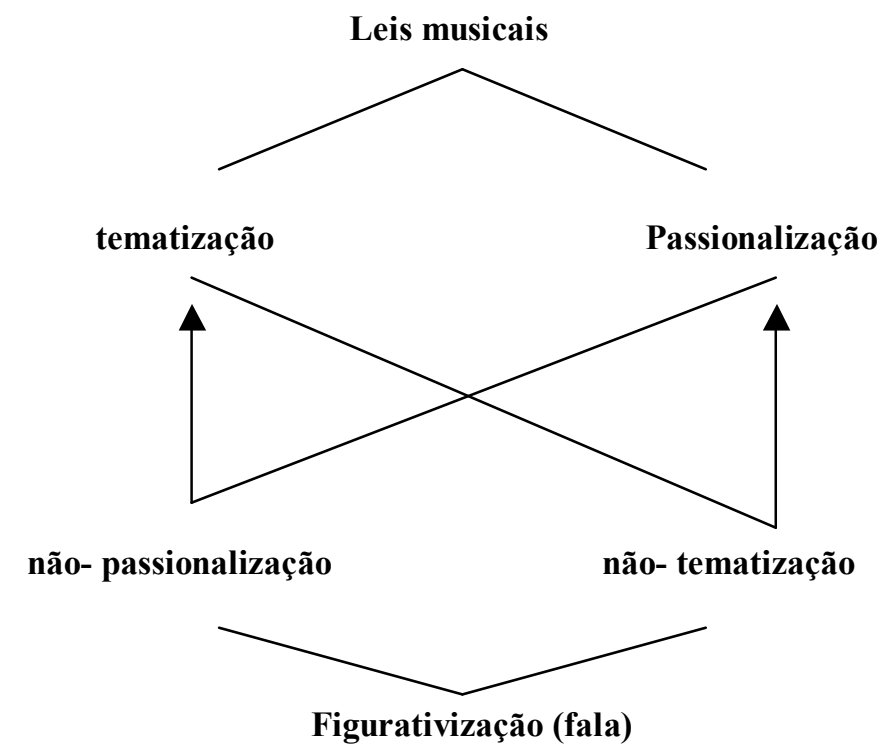

Figura 3

Temos exemplos de tematização na faixa "Viola, meu bem", com a repetição exata da melodia nos versos "Vou me embora pro sertão, ô viola meu bem, ô viola / Eu aqui não me dou bem, ô viola meu bem, ô viola". Observamos o uso do refrão na faixa "Quero essa mulher assim mesmo". Temos desdobramento na faixa "Épico", na qual o final da melodia muda para marcar o retorno à tônica e o fim da estrofe: "Todo mundo protestando contra a poluição / até as revistas de Walt Disney contra a poluição". Encontramos segunda parte na faixa "Tu me acostumbraste", onde gradações descendentes contrastam com as gradações ascendentes da primeira parte. Os mecanismos de involução invocam o uso da memória, enquanto os mecanismos de evolução utilizam o recurso da surpresa. Essa oposição, por si só, já resolve a equação 
informação vs repetição, presente em qualquer composição, garantindo o equilíbrio entre originalidade e redundância.

Encontramos um exemplo de graus imediatos no verso "Quero essa mulher assim mesmo", e gradação ascendente na primeira estrofe da faixa "Tu me acostumbraste". Podemos observar um exemplo de salto intervalar na introdução da faixa "Gilberto misterioso", e uma transposição na segunda apresentação do tema na faixa "Tu me acostumbraste". A escolha e a dosagem de cada um desses recursos provocam efeitos de sentido variados no decorrer de qualquer composição. A oscilação entre graus imediatos e saltos intervalares, por exemplo, atua na percepção da continuidade, que rege a oposição contínuo vs descontínuo, que, associada com outros elementos, atua na percepção de densidade (denso vs esparso).

A figurativização, entendida como o estreitamento do laço entre fala e canção, ou melhor, a aproximação desta em direção àquela, tem como principal fator o desfecho da frase melódica, ou seja, o tonema. É do próprio Tatit a definição que segue:

Os tonemas são inflexões que finalizam as frases entoativas, definindo o ponto nevrálgico de sua significação. Com apenas três possibilidades físicas de realização (descendência, ascendência ou suspensão), os tonemas oferecem um modelo geral e econômico para a análise figurativa da melodia, a partir das oscilações tensivas da voz. Assim, uma voz que inflete para o grave, distende o esforço da emissão e procura o repouso fisiológico, diretamente associado à terminação asseverativa do conteúdo relatado. Uma voz que busca a freqüência aguda ou sustenta sua altura, mantendo a tensão do esforço fisiológico, surge sempre continuidade (no sentido de prossecução), ou seja, outras frases devem vir em seguida a título de complementação, resposta ou mesmo como prorrogação das incertezas ou das tensões emotivas de toda sorte. ${ }^{7}$

\footnotetext{
${ }^{7}$ TATIT, Luiz Augusto de Moraes. O cancionista: composição de canções no Brasil. São Paulo: Edusp, 1996. p. 21.
} 
A identificação de cada um desses elementos no discurso melódico permite o confronto entre os efeitos de sentido provocados pelo texto musical e pelo texto lingüístico, sendo possível então verificar a existência de compatibilidades e incompatibilidades entre ambos, e os efeitos de sentido resultantes dessa superposição de textos que existe na canção.

Com a intenção de facilitar o estudo da canção, Tatit propõe um método de transcrição que "espacializa" a melodia, fazendo com que ela seja facilmente visualizada junto com a sua letra. Esse diagrama serve como campo para a transcrição das alturas melódicas: cada linha corresponde ao intervalo ${ }^{8}$ de um semitom ${ }^{9}$. O número de linhas da tabela corresponde à tessitura ${ }^{10}$ da canção analisada. Cada sílaba da letra da canção é anotada na linha correspondente à nota em que ela é entoada, permitindo a rápida visualização do perfil melódico associado à frase cantada:

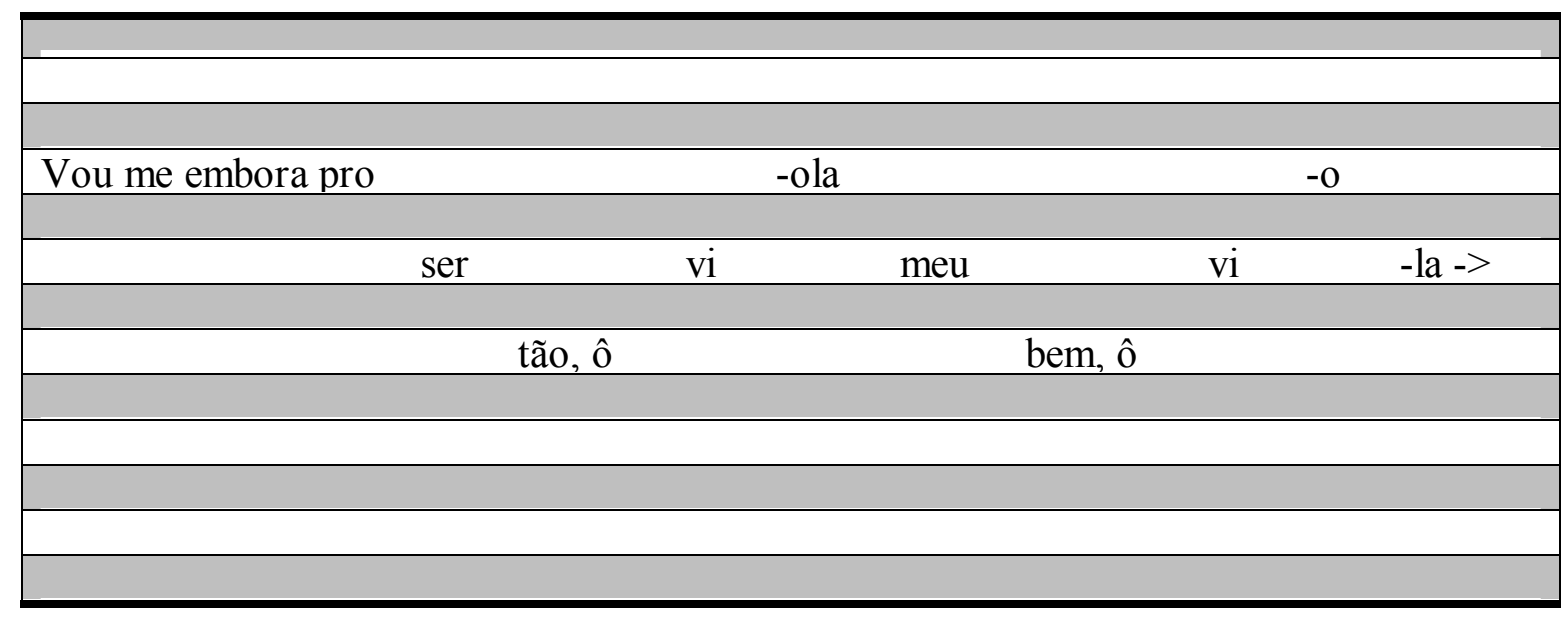

\footnotetext{
${ }^{8}$ Intervalo é a distância entre duas notas musicais, medido em Tons.

${ }^{9} \mathrm{O}$ semitom é o menor intervalo possível entre duas notas na música ocidental.
} 
Desta maneira, melodia e letra podem ser visualizadas simultaneamente. Além disso, o perfil melódico pode ser rapidamente compreendido por leitores que não conhecem escrita musical, como também pode ser imediatamente reconstituído por qualquer instrumento melódico.

\subsection{Análise harmônica}

Em seu aspecto estritamente musical, o modelo de Tatit é voltado quase que exclusivamente para o estudo da melodia, modulada por um aspecto do ritmo que é o andamento. Os processos de tematização, passionalização e figurativização são definidos dentro do perfil melódico, ficando o componente harmônico da canção quase sempre em segundo plano.

O estudo da harmonia pode ser dividido em dois grandes grupos, intimamente ligados. O primeiro deles diz respeito à distribuição das notas internas de um acorde, ou seja, as relações intervalares, os arranjos e disposições organizadas sobre um plano vertical. O segundo se refere ao encadeamento dos acordes, ou seja, sua organização sobre o plano horizontal. A teoria que melhor descreve o funcionamento harmônico da música popular é a harmonia funcional, pertencente ao segundo grupo. Esse método foi sistematizado pela Berkeley Collegge of Music a partir da década de 50 e difundido no Brasil sobretudo pelas obras de Ian Guest e Almir Chediak.

A música tonal, na qual se insere a música popular, é definida pela existência de um eixo polarizado, ou seja, um agrupamento hierárquico de notas (a escala) no qual uma delas tem maior poder de atratividade (a tônica), e pela possibilidade de movimentos harmônicos dentro desse eixo. Desta maneira, o sistema tonal estabelece

\footnotetext{
${ }^{10}$ Tessitura é a distância entre a nota mais grave e a mais aguda de uma música.
} 
uma sintaxe própria que rege os movimentos de acúmulo e dissolução de tensão à medida que a música se desenvolve.

O conjunto de acordes formados por uma mesma escala é denominado campo harmônico. Neste estão previstas três funções harmônicas que descrevem a posição de determinado acorde em relação ao eixo estabelecido pela tonalidade. A função tônica representa a dissolução da tensão harmônica, a resolução. A função dominante, por sua vez, representa o acúmulo de tensão, gerando portanto a expectativa de resolução. Por último, a função subdominante transmite a sensação de afastamento, sendo um grau intermediário entre a dominante e a tônica. O encadeamento dessas funções forma a cadência, bloco coeso que produz o movimento harmônico, tipicamente preparação-resolução (dominante-tônica) e afastamento-preparação-resolução (subdominante-dominante-tônica).

É importante notar que esse é um sistema extremamente flexível. Cada acorde pode admitir sua própria dominante, ou seja, pode ser preparado por outro acorde (mesmo que fora do campo harmônico) ou até mesmo por uma cadência inteira. A harmonia se desenvolve então como um jogo de afastamento e aproximação do centro definido pelo acorde de tônica. A seqüência harmônica pode optar pela não resolução do acorde dominante, gerando expectativa e promovendo o acúmulo de tensão, como também pode se afastar definitivamente da tonalidade original com a proposição de um outro acorde de tônica, estabelecendo um novo eixo de orientação (modulação).

O sistema tonal é baseado em duas escalas principais, a escala maior e a escala menor, cada qual capaz de gerar um campo harmônico autônomo. O campo harmônico menor gera algumas funções não previstas pelo maior (tônica menor, subdominante menor). Normalmente, cada música é desenvolvida sobre uma das duas tonalidades definidas por essas escalas (maior e menor). No entanto, é freqüente o 
deslocamento de acordes de uma tonalidade para a outra, ampliando ainda mais o leque de possibilidades harmônicas. Esse fenômeno é denominado empréstimo modal. Embora não tenha na distribuição interna das notas o seu foco principal, a harmonia funcional também estuda as possibilidades de inversões dos acordes, que produzem as conduções de baixo e o baixo pedal (seqüência de acordes com a mesma nota no baixo).

Infelizmente, essa enorme gama de procedimentos harmônicos ainda não foi descrita de maneira sistemática pela teoria semiótica. Mas por serem ao nosso ver absolutamente fundamentais na construção do sentido da canção popular, tentaremos ao longo deste trabalho estabelecer as relações possíveis entre a harmonia e a análise semiótica, sempre que o assunto tratado assim exigir.

\subsection{Estética tropicalista}

O tropicalismo é o fruto do trabalho de alguns compositores (principalmente) e artistas que não se orientaram no eixo que separava de um lado os defensores de uma "tradição" musical brasileira, e do outro compositores alinhados com as novidades do pop/rock internacional. Esta é, sem dúvida nenhuma, uma oposição insólita do ponto de vista teórico, pois de um lado estavam compositores "engajados" com uma idéia estética conservadora, reunidos graças a um espírito de defesa de valores ameaçados, e do outro compositores e cantores sem a menor intenção de propor um movimento intelectualmente organizado. $\mathrm{Na}$ realidade, eram apenas artistas que dividiam o fascínio por um estilo moderno e a intenção de alcançar o sucesso pessoal. O que sustentava a oposição era sobretudo uma disputa de mercado e de público, protagonizada por esses artistas nos programas de televisão da época. 
Os "tropicalistas" perceberam logo o absurdo desta polêmica, e suas atitudes intencionalmente destoavam das dos demais, por não assumir nenhum dos lados desta rivalidade. $\mathrm{O}$ que predominava em seus gestos era o reconhecimento de ambas as tendências como representativas da cultura nacional, e portanto o "passo adiante" em direção à modernização seria inevitavelmente um processo de síntese. É esse o principal fator que aproxima o tropicalismo do modernismo de Oswald de Andrade. O "fazer tropicalista", assim estabelecido, é uma atualização do antropofagismo do início do século.

O embrião deste acontecimento foi construído em reuniões organizadas por Gilberto Gil, motivado por uma viagem feita a Pernambuco, em 1966, da qual retornara com o intuito explícito de organizar artistas em torno de suas idéias. No entanto, as primeiras reuniões por ele organizadas fracassaram, justamente pelo fato de que suas idéias não encontravam lugar na rivalidade musical da época. Em torno dele permaneceram Caetano Veloso, Capinam e Torquato Neto.

O episódio que levou a público o fazer tropicalista foi a apresentação de “Alegria, alegria”, no festival da canção da TV Record em 1967. Esta canção, que viria a ser a composição mais conhecida de Caetano, foi apresentada com o acompanhamento do grupo de rock portenho "Beat Boys". Apesar do impacto inicial, a canção teve uma excelente e imediata repercussão. Construída a partir de sobreposições de imagens e informações provenientes de diversas fontes, "Alegria, alegria" é um dos maiores símbolos do fazer tropicalista. Neste mesmo festival foi apresentada a canção "Domingo no parque”, de Gilberto Gil, com arranjos de Rogério Duprat. Em 1968, Caetano Veloso lança seu LP homônimo, com as canções "Tropicália", "Clarice", "No dia em que eu vim-me embora", "Alegria, alegria", “Onde andarás”, “Anunciação”, "Superbacana”, "Paisagem útil”, "Clara”, "Soy loco 
por ti, América", “Ave Maria” e "Eles”. Em 1969, é lançado o LP / manifesto tropicalista Tropicália-Panis et circenses.

No nosso entender, o tropicalismo é a chave para a compreensão de toda a obra de Caetano Veloso, não apenas das composições da fase tropicalista propriamente dita, mas também das suas produções pré e pós-tropicalistas. Em recente entrevista à revista Época, Caetano reage à estagnação criativa presente na música popular brasileira com a frase: "sou tropicalista". Isso nos leva a crer que o tropicalismo não se limita ao movimento tropicalista, que tem lugar (espacial e temporal) definido na história da canção brasileira, e tampouco pode ser rotulado como gênero musical, como a bossa-nova ou o rock. $\mathrm{O}$ tropicalismo deve ser entendido como uma série de procedimentos estéticos, políticos e semióticos, que podem surgir, em maior ou menor grau, em qualquer momento histórico e em qualquer ritmo ou estilo musical.

Não faz parte da proposta deste trabalho fazer uma análise profunda da estética nem tampouco uma descrição histórica detalhada do movimento tropicalista. Diversas obras já realizaram, com grande êxito, esta tarefa. Podemos mais uma vez citar os livros Tropicália: Alegoria, Alegria, ${ }^{11}$ Verdade Tropical, ${ }^{12}$ e Tropicália - A história de uma revolução musical ${ }^{13}$, como sendo um bom ponto de partida para a compreensão do fenômeno. No entanto, há uma obra que se orienta particularmente com nossos objetivos. Trata-se do livro $A$ desinvenção do som, de Paulo Eduardo Lopes. ${ }^{14}$ Neste trabalho, Lopes se propõe a extrair os componentes semióticos presentes nas composições dos diversos estilos presentes na década de 60 . O pressuposto teórico para tal empreitada é também extremamente original: a partir dos

\footnotetext{
${ }^{11}$ FAVARETTO, 1979.

${ }^{12}$ VELOSO, Caetano. Verdade Tropical. São Paulo: Companhia das Letras, 1997.

${ }^{13}$ CALADO, Carlos. Tropicália: a história de uma revolução musical. São Paulo: Editora 34, 1997.
} 
conceitos semióticos formulados por A.J. Greimas e Jacques Fontanille, o autor recorre aos conceitos de dialogismo, seguindo o percurso iniciado por Mikhail Bakhtin, e desenvolvido por Julia Kristeva e Dominique Maingueneau, e de "polifonia", centrado nos trabalhos de Oswald Ducrot, para tentar encontrar o "lugar semiótico" reservado ao dialogismo. Com isso, o autor cria uma ferramenta extremamente útil, pois sem "abandonar de todo o edifício pacientemente construído ao longo dos anos"15, consegue entender o texto não somente a partir do próprio, mas principalmente através da relação que este mantém com outros textos com os quais "dialoga".

Esse olhar é particularmente interessante para a análise da canção brasileira da década de 60, em que alguns estilos eram defendidos por seus membros como verdadeiros “cultos ideológicos”, engajados em não só defender sua própria "verdade", mas muitas vezes também em desqualificar a "verdade" alheia. Essa rivalidade transitava simultaneamente na obra e na vida destes membros, produzindo quase que uma caricatura de um "embate ideológico multi-sensorial", composto por letras, melodias, arranjos, declarações, gestos e imagens. A "ideologia" por vezes surgia como conseqüência inevitável do conjunto dessas atitudes, e por outras como um pressuposto teórico norteador do trabalho do grupo. Esse "diálogo", manifestado ora como rivalidade, ora como admiração, foi possível graças a uma série de fatores políticos e socioculturais que definiram o momento histórico que o Brasil atravessava, a diversidade da origem dos membros de cada grupo, e também a força centralizadora de um "inimigo comum": a ditadura militar. Quase sempre, o fator predominante da rivalidade dos grupos vinha da diferença no posicionamento frente à ordem imposta pelo governo militar.

\footnotetext{
${ }^{14}$ LOPES, Paulo Eduardo. A desinvenção do som. Campinas: Editora Pontes, 1999.
} 
O resultado que mais nos interessa do trabalho de Lopes é a definição das matrizes que definem e norteiam o trabalho de cada grupo. Ele propõe quatro categorias de canção: a canção jovenguardista, a canção emepebista nostálgica, a canção emepebista apostólica e a canção tropicalista, definindo em cada uma delas o leque de procedimentos semióticos e seus respectivos sujeitos epistemológicos (os "heróis" de cada vertente).

O "herói” jovenguardista é caracterizado pela crença no "destino, concebido como um /dever-ser/ que rege um devir inexorável e irreversível”. Ele prossegue: “(ser um herói jovenguardista) é dar valor a tudo o que seja considerado diferente e original". Em contrapartida, "é a desvalorização do livre-arbítrio [...]. de tudo o que seja convencional ou normal, ou represente valores tradicionais". Concluindo: "Em geral, esse quadro axiológico é aplicado sobre categorias semânticas relativas ao universo comportamental individual". ${ }^{16}$

Ser um "herói” emepebista nostálgico consiste em "conceber o destino como um /dever-ser/ que rege um devir rítmico e cíclico, como numa espécie de eterno retorno" $"$. Desta forma, este "herói’ não acredita em si como sujeito transformador. Para ele, somente forças externas poderão agir para que este entre outra vez em conjunção com os objetos eufóricos. Mas, ao mesmo tempo, não acredita nesta realização. Ao nosso entender, isso decorre de um conflito de competências: embora o “destino" ou o "tempo" estejam em conjunção com o /saber fazer/ e o /poder fazer/, o /querer ser/ é caro apenas ao "herói”. E este, como vimos, não tem as outras competências necessárias. Ou seja: nenhum dos sujeitos preenche todos os requisitos

\footnotetext{
${ }^{15}$ Ibid. p. 16.

${ }^{16}$ Ibid. p. 188.

${ }^{17}$ Ibid. p. 190.
} 
para a ação, e esta portanto nunca é realizada. Esta configuração produz no sujeito uma paixão definida por Lopes como uma "obstinação resignada". ${ }^{18}$

O "herói" emepebista apostólico é aquele que mais se aproxima ao senso comum do termo "herói". Ele acredita estar em conjunção com todas as competências necessárias para transformar seu estado atual de disforia, e portanto está pronto para realizar a ação de transformação. A narrativa desse "herói" consiste em difundir esta certeza, fazendo com que outros sujeitos entrem em conjução com a competência que possui. Ele está portanto em conjunção com um /dever fazer saber/, ou seja, é um sujeito revelador. É desta maneira que ele transfere as competências individuais para a coletividade.

Segundo Lopes, “o herói do tropicalismo apresenta alguns pontos em comum com cada um desses outros sujeitos". ${ }^{19}$ Ele tem em comum com o jovenguardista a proposta de um "estilo comportamental"; com o emepebista nostálgico a tendência à "perspectiva individual"; com o emepebista apostólico, o "impulso libertador". Só esta constatação já revela a fragmentação da constituição deste sujeito. De certa forma, parece que o fazer do sujeito tropicalista decorre da tensão entre categorias semânticas opostas. Ele é dotado ao mesmo tempo do /saber ser/ e /saber não ser/, /querer ser/ e /querer não ser/. Ele difere dos outros sujeitos principalmente por não propor um posicionamento rígido frente às questões por estes levantadas. Assim como seu discurso, o "herói" tropicalista é uma síntese de todos os outros. Outro ponto fundamental do fazer do sujeito tropicalista é o questionamento não só dos valores

\footnotetext{
${ }^{18}$ Ibid. p. 202.

${ }^{19}$ Ibid. p. 193.
} 
embutidos no discurso, mas também da própria discursivização. Sua proposta de transformação é, acima de tudo, estética.

Transcrevemos a seguir o quadro comparativo a que chega Lopes: 


\begin{tabular}{|c|c|c|c|c|}
\hline $\begin{array}{l}\text { Nivel de } \\
\text { descrição }\end{array}$ & $\begin{array}{l}\text { JOVEM } \\
\text { GUARDA }\end{array}$ & $\begin{array}{c}\text { MPB } \\
\text { NOSTÁLGICA }\end{array}$ & $\begin{array}{c}\text { MPB } \\
\text { APOSTÓLICA }\end{array}$ & TROPICALISMO \\
\hline Precondições & $\begin{array}{l}\text { - Regime } \\
\text { emissivo, } \\
\text { temporalidade } \\
\text { mnésica } \\
\text { - "fala": } \\
\text { regime } \\
\text { remissivo } \\
\text { (temporalidade } \\
\text { cronológica?) }\end{array}$ & $\begin{array}{l}\text { - "canção": } \\
\text { regime emissivo, } \\
\text { na ordem intensa, } \\
\text { e remissivo, na } \\
\text { ordem extensa; } \\
\text { temporalidade } \\
\text { mnésica, regendo } \\
\text { a cronológica } \\
\text { (devir cíclico); } \\
\text { - "não-canção": } \\
\text { regime remissivo, } \\
\text { temporalidade } \\
\text { cronológica. }\end{array}$ & $\begin{array}{l}\text { - "canção" } \\
\text { eufórica: regime } \\
\text { emissivo, } \\
\text { temporalidade } \\
\text { cronológica; } \\
\text { - "canção" } \\
\text { disfórica: regime } \\
\text { remissivo } \\
\text { (temporalidade } \\
\text { mnésica?). }\end{array}$ & $\begin{array}{l}\text { - "canção" eufórica: regime } \\
\text { emissivo, na ordem intensa, e } \\
\text { remissivo, na ordem extensa; } \\
\text { temporalidade mnésica; } \\
\text { - "canção" disfórica: regime } \\
\text { remissivo (temporalidade } \\
\text { mnésica?). }\end{array}$ \\
\hline Fundamental & $\begin{array}{l}\text { • valores } \\
\text { passionais (a } \\
\text { "canção" } \\
\text { exprime o } \\
\text { /amor/); } \\
\text { • valores } \\
\text { veridictórios (a } \\
\text { "canção" é } \\
\text { /verdadeira/, a } \\
\text { "fala" é } \\
\text { /mentirosa/). }\end{array}$ & $\begin{array}{l}\text { • valores ético- } \\
\text { estéticos ( a } \\
\text { "canção" } \\
\text { representa } \\
\text { altruísmo, } \\
\text { solidariedade, } \\
\text { paixão, alegria; a } \\
\text { "não-canção" traz } \\
\text { o egoísmo, a } \\
\text { indiferença, a } \\
\text { dor); } \\
\text { • Valores } \\
\text { veridictórios (a } \\
\text { "canção" é } \\
\text { definida como } \\
\text { /ilusão/ } \\
\text { passageira, } \\
\text { enquanto a "não- } \\
\text { canção" é vista } \\
\text { como /realidade/ } \\
\text { permanente. }\end{array}$ & $\begin{array}{l}\text { • valores } \\
\text { veridictórios: } \\
\text { oposição entre o } \\
\text { /segredo/ ou a } \\
\text { /mentira/ e a } \\
\text { /verdade/ (a } \\
\text { "canção" disfórica } \\
\text { é ocultadora e } \\
\text { enganadora, } \\
\text { enquanto a } \\
\text { "canção" eufórica é } \\
\text { reveladora e } \\
\text { restauradora); } \\
\text { • valores éticos (no } \\
\text { embate entre uma e } \\
\text { outra modalidade } \\
\text { de "canção" estão } \\
\text { envolvidos valores } \\
\text { como justiça vs. } \\
\text { injustiça, } \\
\text { exploração vs. } \\
\text { igualdade, } \\
\text { passividade vs. } \\
\text { luta, etc.). }\end{array}$ & $\begin{array}{l}\text { - valores estéticos (a "canção" } \\
\text { disfórica é marcada pela } \\
\text { estereotipia, passadismo, } \\
\text { sentimentalismo piegas, pelo } \\
\text { traço coletivo, etc.; a "canção" } \\
\text { eufórica é marcada, ao } \\
\text { contrário, pela ruptura como } \\
\text { estereótipo, pela } \\
\text { proprioceptividade, etc.); } \\
\text { • valores éticos (a "canção" } \\
\text { disfórica é opressora, enquanto } \\
\text { a "canção" eufórica é } \\
\text { libertadora); } \\
\text { - valores veridictórios (a } \\
\text { opressão da "canção" disfórica } \\
\text { é acompanhada, em geral, de } \\
\text { uma censura ou um } \\
\text { ocultamento (fazer-não-ver), } \\
\text { que a "canção" eufórica } \\
\text { tropicalista irá denunciar } \\
\text { (fazer-ver). }\end{array}$ \\
\hline
\end{tabular}




\begin{tabular}{|c|c|c|c|c|}
\hline $\begin{array}{l}\text { Nivel de } \\
\text { descrição }\end{array}$ & $\begin{array}{l}\text { JOVEM } \\
\text { GUARDA }\end{array}$ & $\begin{array}{c}\text { MPB } \\
\text { NOSTÁLGICA }\end{array}$ & $\begin{array}{c}\text { MPB } \\
\text { APOSTÓLICA }\end{array}$ & TROPICALISMO \\
\hline Narrativo & $\begin{array}{l}\text { - a "canção" } \\
\text { representa a } \\
\text { conjunção do } \\
\text { sujeito com os } \\
\text { valores de } \\
\text { base da jovem } \\
\text { guarda; } \\
\text { - como objeto } \\
\text { modal, ela } \\
\text { confere um } \\
\text { /poder-saber- } \\
\text { ser/ ao sujeito; } \\
\text { - recobre a } \\
\text { prova } \\
\text { qualificante da } \\
\text { narrativa } \\
\text { jovenguardista }\end{array}$ & $\begin{array}{l}\text { • a "canção" } \\
\text { representa a } \\
\text { conjunção com os } \\
\text { valores eufóricos } \\
\text { e a disjunção com } \\
\text { os anti-valores da } \\
\text { "realidade"; } \\
\text { - recobre a prova } \\
\text { principal do } \\
\text { esquema narrativo }\end{array}$ & $\begin{array}{l}\text { • a "canção" } \\
\text { eufórica representa } \\
\text { a conjunção com os } \\
\text { valores de base e a } \\
\text { disjunção com os } \\
\text { anti-valores da } \\
\text { "canção" disfórica; } \\
\text { • a "canção" } \\
\text { disfórica surge na } \\
\text { fase da prova } \\
\text { qualificante; a } \\
\text { eufórica, na fase da } \\
\text { prova principal do } \\
\text { esquema narrativo }\end{array}$ & $\begin{array}{l}\text { - a "canção" eufórica também } \\
\text { propicia a conjunção do sujeito } \\
\text { com seus valores de base, } \\
\text { opondo-se à "canção" } \\
\text { disfórica, que o leva à } \\
\text { disjunção. } \\
\text { - a primeira recobre a prova } \\
\text { qualificante e a segunda, a } \\
\text { prova principal da narrativa } \\
\text { tropicalista. }\end{array}$ \\
\hline Discursivo & $\begin{array}{l}\text { - temas: amor } \\
\text { perdido, amor } \\
\text { (re)encontrado } \\
\text { (do ponto de } \\
\text { vista } \\
\text { epistemológic } \\
\text { o, o tema } \\
\text { manifestado } \\
\text { pela "canção" } \\
\text { seria o da } \\
\text { restauração do } \\
\text { "destino"; } \\
\text { - figuras } \\
\text { comuns: } \\
\text { "canção", } \\
\text { "cantar", } \\
\text { "ouvir"; } \\
\text { • aspecto: } \\
\text { durativo (em } \\
\text { contraste com } \\
\text { a pontualidade } \\
\text { da fala)?. }\end{array}$ & $\begin{array}{l}\text { • tema da evasão } \\
\text { (do "destino", da } \\
\text { "realidade"); } \\
\text { • figuras comuns: } \\
\text { "samba", "frevo", } \\
\text { "sambar", } \\
\text { "cantar", "ouvir", } \\
\text { "violão"; } \\
\text { • aspecto: pontual } \\
\text { (em contraste com } \\
\text { a duratividade da } \\
\text { "não-canção"). }\end{array}$ & $\begin{array}{l}\text { • tema: revelação } \\
\text { da injustiça (do } \\
\text { ponto de vista } \\
\text { epistemológico: } \\
\text { restauração da } \\
\text { "realidade" e do } \\
\text { "devir"); } \\
\text { • figuras: "canção", } \\
\text { "canto", "samba", } \\
\text { "cantar", "viola"; } \\
\text { • aspecto: durativo } \\
\text { ("canção" eufórica } \\
\text { e "canção" } \\
\text { disfórica)?? }\end{array}$ & $\begin{array}{l}\text { - tema: denúncia da opressão } \\
\text { cultural e seus delegados (do } \\
\text { ponto de vista epistemológico: } \\
\text { questionamento da } \\
\text { "realidade", isto é, das } \\
\text { condições de sua } \\
\text { cognoscibilidade); } \\
\text { - figuras: "canção" } \\
\text { ("Carolina", "Voz do morro", } \\
\text { "Tropicália"), "canto", } \\
\text { "cantar", "emitir acordes", } \\
\text { etc.; } \\
\text { • aspectos: iterativo ("canção" } \\
\text { disfórica), durativo } \\
\text { (eufórica)?? }\end{array}$ \\
\hline & $\begin{array}{l}\text { "canção" vs. } \\
\text { "fala" }\end{array}$ & $\begin{array}{l}\text { "canção" vs. } \\
\text { "não-canção" }\end{array}$ & $\begin{array}{l}\text { "canção" vs. } \\
\text { "canção disfórica" }\end{array}$ & "canção" eufórica vs. disfórica \\
\hline & & & "certa" vs. "errada" & "dizível" vs. "indizível" \\
\hline
\end{tabular}

(Ibid. p. 309-310) 
Embora tenhamos afirmado que o tropicalismo seja a chave para a compreensão da obra de Caetano Veloso, esta é muito maior e mais abrangente que o movimento iniciado na década de 60. Caetano conseguiu e consegue ainda, de acordo com o célebre discurso proferido durante a apresentação da canção "É proibido proibir", entrar e sair de todas as estruturas. Podemos observar uma inclinação de algumas de suas canções para cada uma destas categorias apresentadas por Lopes. Em "Saudosismo", observamos uma aproximação com a MPB nostálgica. Já em “Índio”, manifestam-se elementos próprios à MPB apostólica. No entanto, esta aproximação não resulta em uma coincidência, mas sobretudo em uma referência. Caetano apresenta uma enorme capacidade de articular os elementos constituintes da cultura brasileira, em especial a cultura musical, referenciando-a e questionando-a no interior da sua obra.

O único aspecto ausente (ou menosprezado) no trabalho de Lopes é, ao nosso ver, a colocação da melodia em segundo plano. Seria possível entender a melodia de cada canção como um texto autônomo, que também dialoga com outras melodias e, simultaneamente, com as letras das canções. Essa perspectiva abriria novas possibilidades analíticas, aprofundando ainda mais a capacidade "dialógica" deste texto sincrético que é a canção. Lopes afirma: "O tropicalista parece dizer ao Apóstolo: "antes de pregar contra a opressão e a alienação, certifique-se de que sua própria pregação não é opressora e alienante" (p. 207). Esta afirmação creditada ao sujeito tropicalista encontra um eco profundo na estética da melodia e do arranjo (destacamos aqui a forma e a instrumentação) típicos das composições emepebistas apostólicas. Muito bem entendida a limitação do corpus deste trabalho, fica anotada a possibilidade de desenvolver este interessante desdobramento da teoria, 
complementando a análise proposta por Luiz Tatit, que é exclusivamente intrínseca e não dialógica. 


\section{Projeto Visual}

\subsection{Capa}

A autoria da capa do LP Araçá Azul é creditada a Luciano Figueiredo e Oscar Ramos, com fotos de Ivan Cardoso. O primeiro aspecto a ser trabalhado na análise desta capa é a sua originalidade em relação a outros LPs comerciais da época. A capa é o outdoor de um LP. É normalmente através dela que o comprador trava o primeiro contato com o LP enquanto produto, e é a capa (e não o conteúdo sonoro) que fica exposto nas lojas. Justamente por isso, a capa de um LP é um recurso extremamente importante na identificação, caracterização e divulgação de um trabalho fonográfico. Via de regra, a capa de um LP carrega as inscrições do nome do autor e um título (quando não coincidirem), além de alguma imagem, gravura ou montagem que, supostamente, deveria manter relações com o conteúdo do mesmo. Além de compor, junto com o material sonoro, uma totalidade sincrética (visual e auditiva), ela é também, inevitavelmente, parte de uma estratégia de marketing de divulgação de um produto comercial.

Na capa do Araçá Azul, no entanto, não há nenhuma inscrição verbal que permita uma identificação quer com o conteúdo, quer com o autor. Todas as relações só podem ser estabelecidas através da observação de elementos não verbais, ou seja, dos elementos visuais que compõem a montagem da capa. Esse primeiro dado já descaracteriza o LP enquanto produto puramente comercial, pois a maneira como a capa foi concebida compromete a rápida identificação do mesmo. Tendo a imagem do autor refletida num espelho como elemento central, a identificação da obra pela capa só é possível pelo 
reconhecimento visual do mesmo, o que já pressupõe uma aproximação prévia. O único elemento que "sobreviveu" à intervenção criativa do autor é o logotipo da empresa fonográfica (Philips), no canto superior direito, porém pouco perceptível devido ao fundo escuro em que se encontra. Por outro lado, a montagem é extremamente bem sucedida na sua finalidade de antecipar o conteúdo do LP. Criada a partir de fragmentações e sobreposições, ela é uma excelente representação visual dos processos empregados na composição sonora do disco. A partir de uma observação superficial da capa, já é possível caracterizar o LP como um trabalho eminentemente experimental, e antever nele um conteúdo conceitual, mais do que uma simples coletânea de canções.

O elemento principal exposto é a imagem de Caetano Veloso refletida no espelho, em posição oblíqua. Nesta, ele aparece com o corpo desnudo, trajando apenas uma sunga vermelha. Seu rosto está parcialmente encoberto pelos cabelos e pela sombra dos mesmos. Não há nenhum traço significativo perceptível na expressão facial. Atrás do compositor, folhas de palmeira contrastando com um céu azul. Ocupando o extremo direito, em posição vertical, está a imagem da barriga do compositor, também desnuda. Abaixo e à esquerda, está sobreposta a imagem de um pé descalço, pisando na grama verde, enquanto acima e à direita foi sobreposta a imagem de um pedaço do tórax, vestido com uma blusa preta.

A partir do elemento principal, que é o próprio autor da obra mirando-se no espelho, é possível extrair o sentido de busca de identidade. O sentido de "busca" é ainda mais acentuado pelo fato de o rosto estar encoberto. Essa busca nos é então apresentada como um processo em andamento, traço reforçado pela neutralidade da expressão facial. É interessante a oposição desta busca com a proposta tropicalista da década de 60. Enquanto aquela lançava mão de diversas alegorias para caracterizar o fazer artístico, aqui Caetano se 
apresenta completamente despido. O cenário intercultural (hoje diríamos "globalizante") proposto pelo movimento tropicalista é trocado por uma paisagem praiana, natural, composta pelas palmeiras, pela grama e pela indumentária mínima. Todos esses elementos nos permitem classificar essa busca como uma busca de identidade, já estabelecendo uma relação desta com o espaço de origem do compositor.

Esse ato de buscar caracteriza a cena como um momento de veridicção, orientada pela égide do /saber/. A modalidade do /saber/ estagna o curso do devir, para medir a sua evolução. Confrontando essa cena com a trajetória de uma das figuras mais importantes do movimento tropicalista, é possível deduzir que Caetano está nesse momento propondo uma avaliação dessa trajetória.

Circundando o elemento principal, temos três elementos secundários que caracterizam a fragmentação da imagem refletida. O que ocupa maior proporção é a imagem do abdome do autor, no lado direito. É esta a imagem que está em primeiro plano, e a montagem leva a crer que esta é a imagem que dá origem à imagem refletida. São dois os componentes que podem ser destacados dessa imagem: o umbigo e a gestação. $\mathrm{O}$ destaque para o umbigo, cicatriz deixada pela queda do cordão umbilical, remete à ligação com os elementos de origem. A gestação é metáfora do processo de criação, ou ainda, da criação em estado embrionário. Com essa imagem, Caetano circunscreve um espaço dotado de historicidade, onde convivem tanto sua obra como sua origem. Além disso, a gestação reforça a idéia de projeto em andamento, de processo. Desta maneira, o compositor está refletindo não só sobre a sua individualidade, mas também sobre a sua obra - e ambas nos são apresentadas pela imagem refletida no espelho. É interessante o efeito de sentido criado por esse paradoxo: ao mesmo tempo em que Caetano exibe o seu interior despido, sua 
essência só nos é apresentada a partir da sua imagem refletida, provocando um efeito de revelação e, ao mesmo tempo, de mistério.

Os outros dois elementos secundários são apresentados como sobreposições, caracterizando a imagem da capa como sendo uma montagem manipulada. Nesta, o corpo do autor está fragmentado. São dois os efeitos de sentido decorrentes dessa montagem. O primeiro decorre diretamente do fato de a imagem do autor ter sido manipulada, não sendo mais uma representação do mundo natural. A ação do homem como agente transformador da natureza é então evidenciada. O outro efeito decorre da fragmentação. Esta técnica é essencialmente tropicalista, explorada em canções como "Alegria, Alegria” e "Geléia Geral”. Retirando cada elemento de sua posição natural, a fragmentação evidencia não só cada elemento individualmente, mas também evidencia do ponto de vista paradigmático o processo que os une. Em outras palavras, a fragmentação tanto é decomposição (quando parte da unidade e evidencia os elementos componentes) como também composição (quando a partir dos elementos componentes, compõe a unidade). Todos esses efeitos de sentidos provocados pela capa do LP (origem, criação, fragmentação, busca de identidade) encontrarão eco no material sonoro do LP.

Os elementos do nível plástico de um texto visual são definidos a partir de duas categorias constitucionais (eidética e cromática) e categorias não constitucionais (também chamadas de relacionais), topológicas. O LP é uma "tela" quadrada: temos então a definição de dois eixos (vertical e horizontal) e duas diagonais, ligando os ângulos deste quadrado. É interessante notar que enquanto os eixos podem ser determinados a partir de uma oposição simples (alto vs baixo e esquerdo vs direito), as diagonais são compostas de maneira complexa, visto que cada ângulo precisa das informações dos dois eixos para ser 
definido (alto/ esquerdo, baixo/direito, etc...). Além disso, o encontro das diagonais define um centro, dividindo o plano em região central e periférica.

Na capa do Araçá Azul, a imagem refletida está parcialmente alinhada com a diagonal que liga os ângulos alto/esquerdo e baixo/direito. Esta imagem é o reflexo de quase todo o corpo do compositor, e ocupa a posição central da capa. Os outros três objetos (pé, barriga e tronco) estão alinhados com os eixos horizontal e vertical, e ocupam posições periféricas. São imagens diretas (não refletidas) e fragmentadas. Temos então o seguinte quadro de oposições:

$$
\begin{aligned}
& \text { oblíquo - central vs ortogonal - periférico } \\
& \text { refletido - inteiro vs direto - fragmentado }
\end{aligned}
$$

Esta capa pode ser interpretada como a descrição de uma transformação: a passagem do fragmentado para o não-fragmentado, ou seja, uma operação de síntese. É interessante notar que a "soma" dos elementos figurativos foi recoberta também por uma operação semelhante no nível eidético - a passagem do ortogonal ao diagonal. O resultado desta síntese é a criação de um elemento complexo.

Ainda no plano eidético, podemos observar o uso exclusivo de traços curvos separando cada objeto. No quadrante superior esquerdo, ressaltamos a forma circular definida pelos cabelos do compositor na imagem refletida.

A principal oposição cromática é estabelecida dentro da imagem refletida, entre os objetos naturais (céu, plantas e o corpo nu - cores frias) e artificiais (a sunga - cor quente). 
Estas oposições serão articuladas não só com os outros elementos visuais (como veremos a seguir) mas também com categorias extraídas do material sonoro.

\subsection{Contracapa}

$\mathrm{Na}$ contracapa do LP encontramos os elementos que tradicionalmente ocupam a capa de um LP convencional: o nome do compositor, o título da obra, o nome e o logotipo da gravadora, o número de identificação do produto. O título e o nome do compositor estão impressos em letra de forma, na cor azul. A imagem apresentada é a foto de um araçá, manipulada, na cor azul.

O araçá é um arbusto típico da costa atlântica brasileira, também conhecido como araçazeiro, de folhas simples e aromáticas. Ele fornece o fruto de mesmo nome, o araçá, comestível e muito apreciado, também conhecido como goiabinha. Fruta que vai do amarelo-pálido ao avermelhado, o araçá é muito comum na região do recôncavo baiano. A manipulação cromática fica então evidente: o araçá apresentado na contracapa do álbum não é um araçá natural, mas explicitamente transformado.

Com a figura do araçá azul, Caetano reapresenta a idéia de identidade nacional, já que o araçazeiro está presente na maior parte do litoral brasileiro. Também está presente a alusão ao espaço de origem do compositor (recôncavo baiano). No entanto, Caetano introduz o sema da artificialidade, com a deformação cromática da fruta. Esse "desvio ao azul" não se limita à imagem do fruto, mas atinge toda a contracapa do álbum: o fundo e os créditos. Só escapam à deformação os elementos impressos pela gravadora, o que deixa 
claro que eles não fazem parte da concepção artística da contracapa, mas estão presentes apenas para a identificação de um produto industrial.

A alusão à expressão "Araçá Azul” aparece em outras composições de Caetano. Na música "Drume Negrinha", versão da música "Drume Negrita", última música do lado A do disco Qualquer Coisa (1975), Caetano faz uma outra referência ao araçá, explicitando o emprego do adjetivo azul:

Se Tu drume eu te trago um araçá

Azul da cor do mar

E na música "A outra banda da terra":

...não erra quem anda

Nessa terra da banda

Face oculta, azul do araçá

Nessas duas canções, o "araçá azul” é apresentado como elemento eufórico. No primeiro caso, ele serve de objeto positivo à estratégia de manipulação do enunciador, apresentado (supostamente à uma criança) como recompensa por dormir. No segundo, ele é apresentado como elemento secreto (face oculta) de uma sanção positiva (não erra quem anda nessa terra).

O monocromatismo é o principal elemento do nível plástico evidenciado na contracapa do LP. É possível estabelecer uma relação entre monocromia vs policromia 
(termo ausente) e artificial vs natural, já que o mundo natural não é monocromático. Com essa relação semi-simbólica, o sema artificialidade, que já estava presente na simples apresentação de um araçá azul, é fortemente enfatizado, já que o azul é a única cor presente nessa montagem.

Temos aqui uma organização espacial muito semelhante à capa. $\mathrm{O}$ talo em que se encontra o fruto também é alinhado com a diagonal, só que desta vez a que liga os ângulos alto/direito e baixo/esquerdo. Além disso, também temos no quadrante superior esquerdo um elemento arredondado. A associação entre o talo/corpo e fruto/cabeça fica então autorizada pela construção apresentada no nível eidético.

O fruto é destacado do talo pela saturação da cor, e do fundo pela nitidez do foco. Os elementos verbais seguem a orientação horizontal, centralizados ao alto (nome do compositor) e abaixo (nome do LP).

\subsection{Encarte central}

O encarte central é uma montagem com várias fotografias. A página dupla foi dividida em três colunas. A coluna central é a mais larga, ocupando mais da metade da área disponível. Esta coluna central é dividida em três partes desiguais: a parte do meio é a maior, e nesta Caetano aparece deitado na praia, de braços abertos, como que crucificado. Na parte inferior desta coluna estão os nomes das músicas e os créditos. Na parte superior, estão inscritos os seguintes dizeres: 


\section{UMIDISCO PARA ENTENDDIDOS}

bolanieve-herminia silva-clementina de jesus-

dinailton-d.morena-

Com esta afirmação, o autor já cria uma expectativa maior acerca do conteúdo da obra, além de jogar com o duplo sentido, pois "entendidos", na época, era uma gíria que hoje se entenderia como "gay". A escolha de uma expressão de duplo sentido, posicionada no encarte em um lugar de destaque (como se fosse o "título" do encarte central), é uma forma interessante de apresentar a obra. É como se o autor desse uma "dica" sobre como a informação vai ser tratada no trabalho. O duplo sentido é sempre uma tensão entre duas possibilidades de resolução. O autor cria uma atmosfera de mistério e ambigüidade ao mesmo tempo em que desvela uma possibilidade de revelação. É também uma retomada do tema identidade, só que desta vez aplicado à questão de identidade sexual.

Um detalhe importante é mudança da canção-título "Araçá Azul", que aparece "Araçá Blue", no encarte central e no encarte interno - no selo do disco o nome está em português.

$\mathrm{Na}$ coluna esquerda, também dividida em três partes, observamos no primeiro retângulo o título do disco em azul, com um fruto de araçá, também em azul. Nesta foto, não há monocromia, sendo observado o verde das folhas atrás do fruto. Abaixo, Caetano admirando-se outra vez no espelho, e mais abaixo olhando à frente, sério e introspectivo.

Na coluna direita, dividida em apenas duas partes, Caetano está no mar, ao lado de garotos negros nadando e jogando bola. Abaixo, aparece à frente de um muro azul, 
descolorido. Nesta coluna existe a inserção de uma fotografia de Dona Edith, tia de Caetano, tocando prato, instrumento comum em samba de roda na região do recôncavo.

O sema da artificialidade é reapresentado com a imagem do araçá azul. Existe uma isotopia da identidade nacional, presente nas imagens do araçá, e dos garotos negros jogando bola. Uma outra isotopia criada é a dos elementos de origem, com as imagens de D. Edith tocando prato, e da paisagem praiana. A busca de identidade é apresentada pelas imagens de Caetano refletida no espelho, e a do rosto parcialmente coberto.

A palavra "araçá" vem do tupi-guarani (ara+çá). Em tupi, "ara" pode significar arara ou dia. Em latim, a mesma palavra "ara" tem outros significados. "Ara" é um lugar reservado ao sacrifício, e também a pedra sobre a qual o sacerdote estende o corporal e coloca o cálice e a hóstia, para celebrar a missa. "Ara da cruz" é a cruz em que Jesus Cristo foi crucificado. Ao mesmo tempo, "ara" representa uma identidade nacional, e um lugar sagrado.

A utilização do termo araçá-blue nos créditos do encarte central e interno do disco se opõe a toda uma constelação de elementos que apontam para a construção de uma identidade nacional. A citação do cantor cubano Bola Nieve e o termo "blue" são as duas únicas manifestações de elementos não nacionais em todo o projeto artístico visual do LP. Essas duas citações trazem informações musicais: a voz suave do cantor cubano negro e o estilo musical mais característico dos negros norte-americanos - o blues.

O blues é um estilo musical que é tradicionalmente usado para transmitir um conteúdo de melancolia, ausência e saudade. Araçá-blues é então uma nova designação para um estilo de música que exterioriza a dor interna, solitária e melancólica, não mais do negro norte-americano longe de sua África (origem), mas do retirante do recôncavo longe 
de sua terra e seus costumes. O azul do araçá ganha então um componente de significado disfórico, e sua deformação cromática passa a ter um caráter de degeneração, de perda dos valores de origem.

Também é significativa a referência à cantora Clementina de Jesus. Empregada doméstica por quase toda a sua vida, negra e analfabeta, Clementina tornou-se um símbolo de várias gerações de compositores e cantores brasileiros que, a despeito de sua origem humilde, escreveram a história da música brasileira, mais particularmente a história do samba. Dotada de uma voz estridente e de uma interpretação que beirava o rústico, a simples citação de seu nome no encarte invoca não só uma importante parcela da música brasileira, mas também toda a história social de seus compositores e cantores.

Esse trio de citações (Bolanieve, Clementina e o Blues) já desenha uma perspectiva de aproximação e síntese que encontrará eco no decorrer do LP. Ao unir esses três elementos geograficamente separados, Caetano aponta para os traços comuns não só da produção musical das três regiões, mas também para a proximidade de sua origem étnica. A escolha dos representantes não poderia ser melhor: temos a América de língua inglesa, espanhola e portuguesa, representados por descendentes de africanos. Ao mesmo tempo em que se retoma o tema da síntese, aprofunda-se também a questão da perda de identidade de origem. O resultado disso é o prenúncio de uma percepção (que se tornará mais explícita nas faixas do LP) de recomposição da identidade após um processo de perda (ruptura).

No nível plástico observamos uma retomada da oposição estabelecida entre a capa e a contracapa. Nos dois primeiros quadrados, no canto superior esquerdo, podemos observar o araçá preso ao talo diagonal, e logo abaixo mais um reflexo de Caetano no espelho, na outra diagonal. Mas ao observar a montagem como um todo, fica evidente o forte contraste 
entre os traços curvos e oblíquos que dividem os objetos da capa e os traços retos e ortogonais que dividem as imagens do encarte central. A composição deste encarte tende para uma linguagem mais jornalística, objetiva, representativa do mundo natural, contrastando com a capa, que sugere uma linguagem mais subjetiva.

Aqui também podemos perceber uma oposição entre central e periférico. Nas imagens periféricas, menores, temos a predominância de elementos verticais no primeiro plano, com a dupla exceção no quadrante superior esquerdo (o compositor e o fruto). Todas as imagens periféricas retratam corpos humanos de maneira parcial. Na imagem central, maior, quase todas as linhas são horizontais, e é a única representação de corpo inteiro de todo o projeto gráfico. O corpo do compositor está paralelo às ondas e às linhas formadas pelas falhas na grama em que está deitado. Essa orientação observada no plano da expressão nos permite estabelecer uma nítida relação com o plano do conteúdo: Caetano está alinhado com os elementos naturais que formam a sua paisagem de origem.

\subsection{Encarte interno}

O encarte central apresenta uma imagem de Caetano com o rosto parcialmente encoberto pelos cabelos, o nome das faixas e seus compositores, e a ficha técnica. No verso, encontramos as letras das músicas e o selo da gravadora. A única cor é o azul.

Mais uma vez são apresentados os semas da busca de identidade (rosto encoberto) e da artificialidade (imagem monocromática). 
A partir dos novos elementos apresentados, é possível estabelecer a relação monocromia vs policromia e perda de identidade vs identidade.

\subsection{Conclusões}

A análise dos elementos visuais elencou diversos traços de sentido que serão trabalhados auditivamente no LP. Foram traçadas as isotopias da busca de identidade, dos elementos de origem, da identidade nacional, da artificialidade, e os temas do processo de criação e da composição/decomposição, da degeneração e da perda dos valores de origem. A observação da reiteração desses elementos nas diversas faixas do LP evidencia o caráter sincrético desta obra. O estudo comparativo de outros LPs poderia propor uma tipologia de relações entre projeto visual e projeto musical de um LP, e estabelecer parâmetros para classificar as diversas funções do projeto visual no projeto geral da obra. 


\section{Projeto Musical}

\subsection{Viola, meu bem}

A primeira música do disco, "Viola, meu bem", é um samba de roda tradicional, anônimo. Nos créditos, a indicação de que é cantado por Edith Oliveira, a dona Edith, tia de Caetano, que também toca o prato. O acompanhamento é de Luciano Oliveira, no atabaque e no pandeiro.

É possível notar claramente, mesmo em uma primeira audição, que esta faixa é composta por dois momentos interligados porém distintos, cada qual perfazendo uma canção absolutamente autônoma. Nosso trabalho será o de levantar os elementos que comprovam esta percepção, analisar as conseqüências dessa técnica de composição para a construção do sentido desta faixa e a estratégia utilizada para compor uma unidade com estas duas canções.

No primeiro trecho, desenvolvido no tom de Fá\# maior, ouvimos apenas uma voz acompanhada pelo atabaque.

Vou me embora pra o sertão, ô viola meu bem, ô viola

Eu aqui não me dou bem, ô viola meu bem, ô viola

Sou empregado da Leste, sou maquinista do trem

Vou me embora pra o sertão, que eu aqui não me dou bem

ô viola meu bem, viola, ô viola meu bem, viola 
A letra representa o desabafo de um trabalhador que não se adapta à vida de empregado da companhia de trem (a Leste-Oeste). Há uma construção bastante interessante já nessa primeira passagem. É muito freqüente a citação do instrumento musical nas letras de músicas populares, diretamente (viola, violão), ou por intermédio de metáforas, adjetivos ou apelidos (meu pinho). Na maioria das vezes, o arranjo musical se compromete com o que está sendo dito pelo intérprete, e apresenta o instrumento citado na letra, geralmente em posição de destaque (introdução e solos). Essa é uma estratégia importante no sentido de sustentar o efeito de realidade criado pela instauração de um sujeito falando em primeira pessoa. A figurativização utilizada na letra ecoa no arranjo, e o timbre característico do instrumento citado concorre para uma figurativização sincrética. Esse efeito é ainda mais acentuado quando ocorre a personificação do instrumento na letra, que assume o papel de segunda pessoa no discurso, e no arranjo atua "respondendo" melodicamente às frases musicais entoadas pelo intérprete. Toda a canção transcorre como um diálogo lingüístico-musical, que pode até chegar a uma verdadeira dramatização. Em algumas canções, o instrumento age como uma arma de defesa e ataque (é conhecido o uso desta técnica para a encenação de "duelos"), em outras ele é um recurso para a distensão passional e apoio psíquico do sujeito.

Nesta canção ocorre algo muito diferente. Apesar de a viola ser incorporada e personificada na letra, ela simplesmente não aparece no arranjo instrumental. Mas ela é colocada no texto como segunda pessoa, e portanto está presente na cena instaurada pelo discurso do trabalhador. Mas está muda. Esta ausência no plano musical acentua drasticamente a tensão passional vivida pelo sujeito. A viola é o símbolo que representa todo o sentimento de falta vivido pelo narrador, ou seja, atua no texto como um reforçador 
do termo "sertão". A intimidade e intensidade com que aquele se refere a esta mostra o apego que existe entre o narrador e o sertão, definindo claramente o seu eixo de valores. Esse sentimento é nitidamente um sentimento de apego à terra natal. $\mathrm{O}$ profundo sentimento de falta que o sujeito nutre por esses objetos representa a ligação que ele mantém com seus valores primordiais, com a sua origem. A busca da conjunção com esses objetos primordiais será uma tônica no álbum.

O emudecimento da viola no arranjo da música mostra que o sentimento disfórico não decorre simplesmente da saudade. Há uma força externa, opressora, agindo para que a viola se cale. Essa força é figurativizada pela imagem da ferrovia, a "Leste". A "Leste" é o Destinador, que o prende longe do objeto e ainda o coloca em conjunção com o anti-objeto, o "trem". Existe um contrato entre a "Leste" e o S1, pois este é empregado daquela, o que pressupõe uma relação contratual entre Destinador e Destinatário. Do ponto de vista do S1, trata-se na verdade de um Anti-Destinador, colocando o sujeito em conjunção com valores disfóricos e afastando-o dos valores eufóricos.

A ausência da viola também atua como um desqualificador do sujeito, pois de certa maneira evidencia a competência da força opressora em opor-se a ele. Isso faz com que a afirmação proferida pela voz solitária soe débil e desacreditada: "vou me embora pro sertão". Ao contrário de uma certeza, o efeito desta afirmação é de um desejo que de antemão se sabe não realizável.

Há uma ênfase muito nítida na separação geográfica entre o "espaço eufórico" e o "espaço disfórico". O sujeito "eu” está em conjunção com valores disfóricos, sincretizados no espaço em que se encontra ("aqui"), e em disjunção com os valores eufóricos, sincretizados no espaço "sertão". A análise da letra da canção nos leva a crer que ele está 
em estado de espera: tem a modalidade do /querer fazer/ ir embora, mas não a do /poder fazer/. O diálogo estabelecido entre a letra e o arranjo sugere a presença de um /saber não poder fazer/ residual. Em outras palavras, o sentimento de revolta (que mobiliza) e de resignação (que estagna) estão em conflito, mas em equilíbrio. Esse complexo perfil passional ressoa em cheio na melodia da canção.

Este primeiro trecho, desenvolvido no tom de Fá\# maior, tem a tessitura de uma oitava, indo de uma nota Fá\# no grave a outra nota Fá\# no agudo. Isso significa que tanto a nota mais aguda quanto a mais grave da canção são notas fundamentais do acorde de tônica, ou seja, representam um repouso melódico. Apesar do andamento razoavelmente rápido da marcação do atabaque (Andante - 109 batimentos por minuto), não fica plenamente caracterizado nesta canção o emprego do regime de aceleração como projeto entoativo principal. A razão disso é o fato de a voz não se ater a um andamento preciso, interpretando ad libitum $^{l}$ por sobre a marcação percussiva. Os recortes rítmicos do atabaque são diluídos pela livre interpretação vocal. Há na verdade uma dissociação entre esses dois elementos, como se um /fazer/ - ligado ao movimento do atabaque - estivesse caminhando paralelamente a um /ser/ - apresentado pela curva melódica livre e desacelerada da voz. Esse recurso aumenta a eficácia da letra em convencer o ouvinte da veracidade do seu conteúdo. O /fazer/ não consegue se projetar sobre o /ser/ para transformar o seu estado, mas também não o abandona. Desta forma, o conflito passional vivido pelo sujeito está impregnado no próprio arranjo instrumental da canção.

\footnotetext{
${ }^{1}$ Sem pulsação determinada.
} 
Observamos a tematização como elemento de involução de ordem intensa já no primeiro verso da canção, reiterada pela repetição exata da frase melódica no segundo verso:
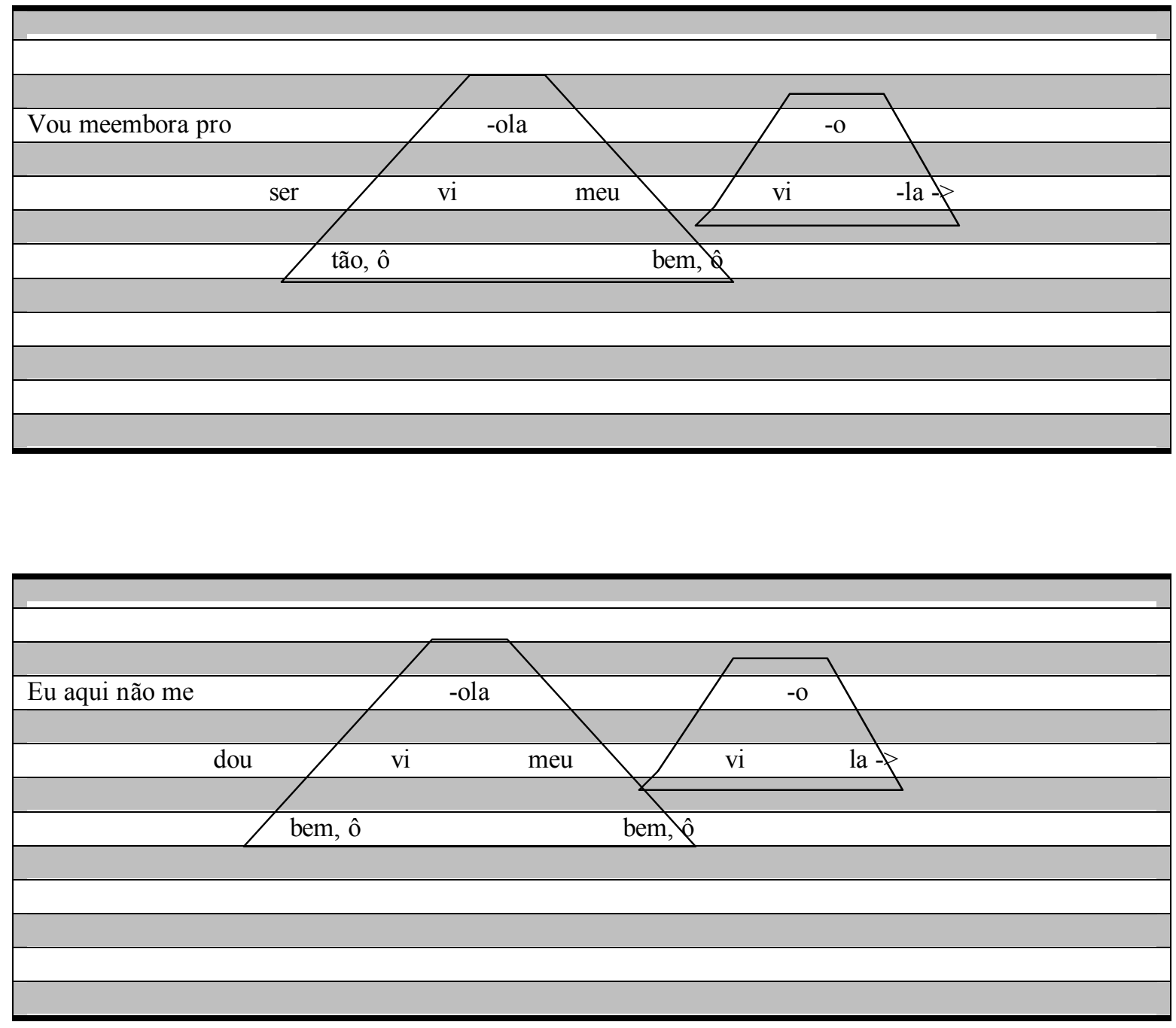

A tematização é um elemento de involução porque, ao estabelecer uma repetição, retarda o aparecimento de informação musical nova. Ao mesmo tempo em que impede a desorganização da melodia, atenua a percepção do pulso (que "força” a música a "andar") por ativar o uso da memória. Ela segura o andamento, e impõe uma distensão relativa sobre 
a tensão de um pulso rápido. Essa tematização é um recurso que também sustenta, no plano lingüístico, a criação de um personagem: a viola.

É importante ressaltar também a ocorrência exclusiva de tonemas descendentes, o que gera o efeito de sentido de afirmação. Esse efeito é reforçado pelo fato de as notas finais desses tonemas coincidirem com a fundamental dos acordes em que elas se encontram. Temos então, além do efeito de distensão provocado pela curva descendente, um efeito de resolução melódica (repouso).

Um movimento de evolução de ordem extensa é apresentado em seguida, com a apresentação de uma segunda parte, definindo um novo tema. Esse novo tema apresenta, no plano lingüístico, um novo personagem, anteriormente identificado como o caipira. É importante notar que este tema é a inversão do primeiro, executado em registro mais grave:

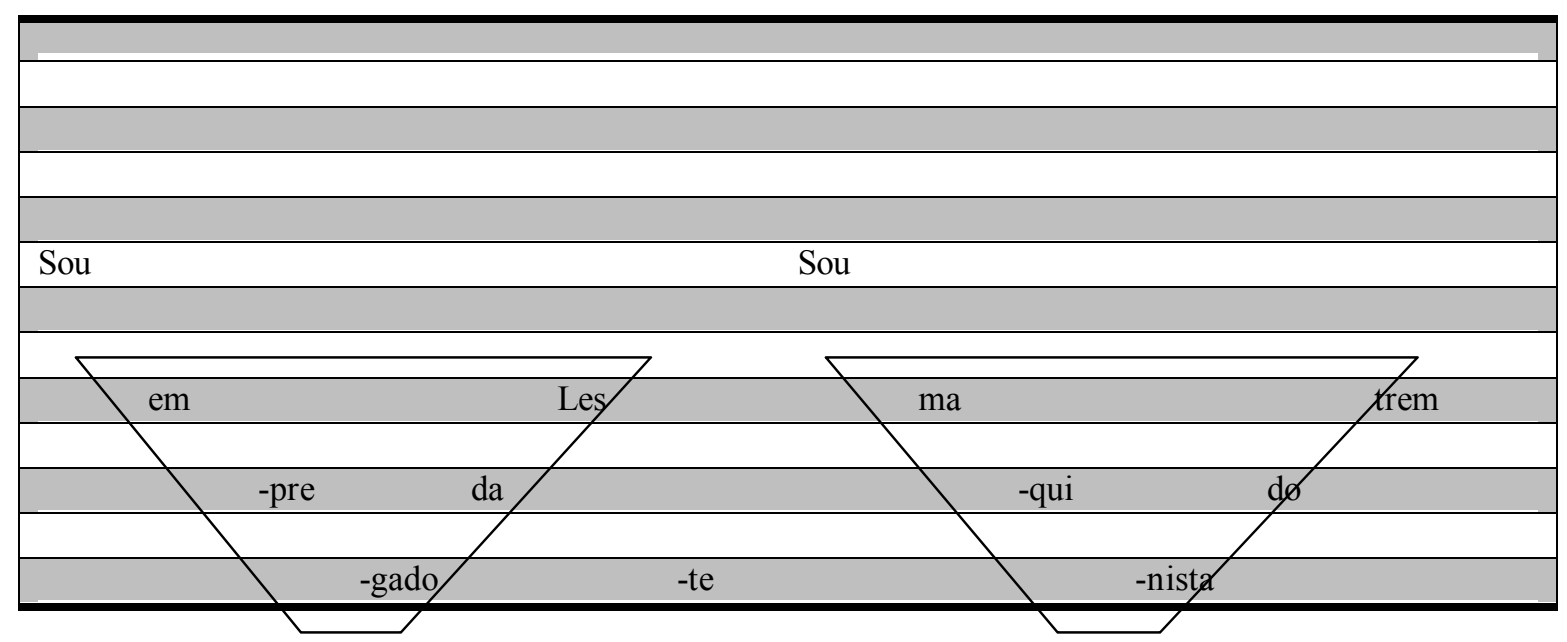

O uso de movimentos de evolução é imprescindível para que a música não se torne demasiadamente repetitiva. É neste ponto que o compositor introduz informação musical nova, o que gera surpresa e ao mesmo tempo expectativa de retorno. É uma estratégia para 
manter o ouvinte atento, gerando um acúmulo de tensão. Apenas ressaltamos o fato de que esta "novidade" é relativizada em parte pela própria tematização deste novo trecho, em parte pelo fato do novo tema ser um desdobramento do primeiro.

Notamos que, assim como na letra, há um equilíbrio entre tensão e distensão na melodia desta canção. O pulso (não muito) rápido é desacelerado pelo uso da tematização. A surpresa causada pela introdução da segunda parte é diluída com uma nova tematização e pelo desdobramento temático.

A terceira parte da canção se opõe às duas primeiras por apresentar grandes saltos intervalares. A melodia vai do extremo grave ao extremo agudo nos dois primeiros versos. Esse movimento gera um acúmulo de tensão que atinge seu ápice no extremo agudo da frase melódica, para ser então resolvida na frase descendente, que retorna abruptamente ao extremo grave.

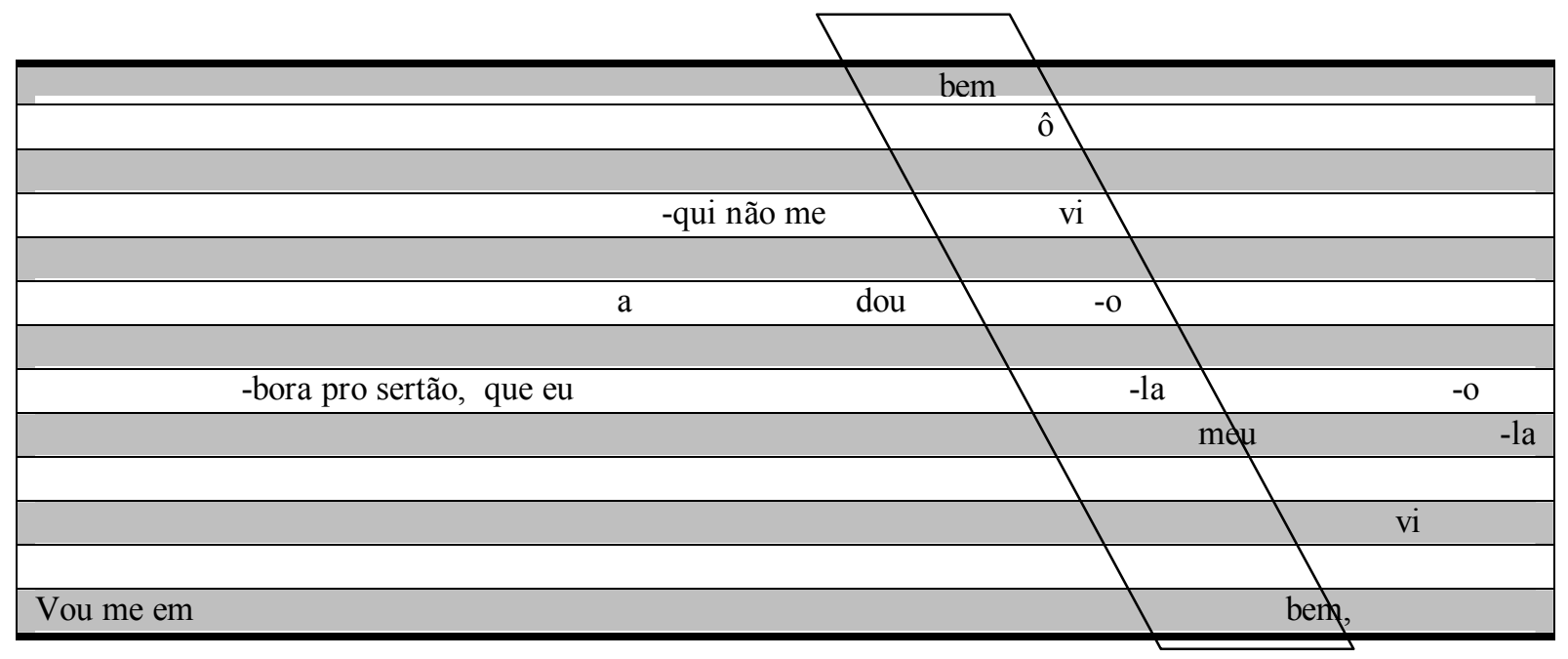




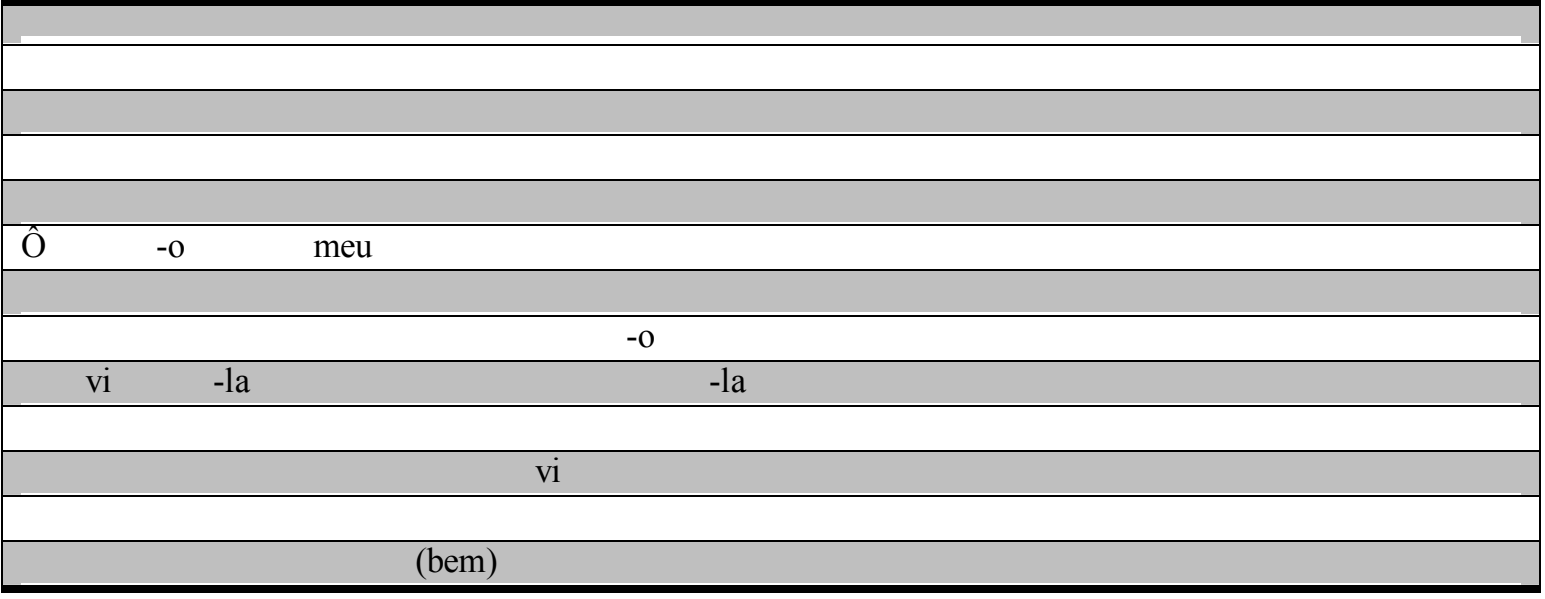

Esta grande frase descendente é um ícone de tudo o que falamos até agora. Ela atinge o extremo agudo da tessitura, o ponto de maior tensão vocal.

Além disso, essa nota é alcançada através de um salto intervalar. No entanto, esse ponto de tensão é diluído pela resolução harmônica, e pelo fato de a nota mais aguda ser uma fundamental. Em seguida, a tensão dissolve-se gradualmente até atingir o extremo grave, também uma fundamental, ponto de menor tensão melódica.

É interessante notar que a frase eleita para este ponto importante é "eu aqui não me dou bem". O destaque é dado para o sentimento disfórico vivido pelo narrador, o que certamente acentua a sua percepcão. Mas este acento não recai sobre a ação propriamente dita, inscrita no verso "vou me embora pro sertão". Este é mais um elemento que age para reforçar a idéia de que esta frase relata muito mais um desejo do que a certeza de uma ação futura. Logo após a frase descendente, o tema inicial é revisitado. Mas a melodia aos poucos dá lugar à fala, desestabilizando o projeto entoativo. Tudo ocorre como se o narrador tivesse gastado toda a energia disponível para atingir o ápice de tensão, não lhe restando forças para manter o fio melódico. Torna-se impossível crer na veridicção do 
/fazer/ (ir embora) narrado na letra. Automaticamente, fica comprovada a competência da força opressora em manter o sujeito em disjunção com os objetos disfóricos.

Apesar de todo o projeto entoativo da canção estar inclinado para a tematização, a interpretação vocal (e em parte o arranjo instrumental) nega essa inclinação, introduzindo elementos que desaceleram a curva melódica. O prolongamento das vogais é claro nos finais de todos os versos. Essa duração conferida às vogais deixa transparecer o processo de passionalização, que acentua a manifestação do /ser/ sobre o devir melódico. De uma maneira geral, toda a interpretação vocal, com a pronúncia clara e pausada, contribui para essa sensação de desaceleração. Esse efeito de passionalização reflete na melodia o estado disjuntivo e o alto teor de tensão passional relatado na letra da canção. O outro fator que acentua o efeito de passionalização observado na interpretação é a baixa densidade do arranjo de base, composto apenas pelo atabaque. Apesar de ser este um instrumento de marcação rítmica, não há um elo que o una com a voz. Esta parece desenvolver-se livremente acima da marcação constante do instrumento percussivo. Mais uma vez, observamos uma construção que confronta opostos: a marcação rítmica, que acelera, e os mecanismos de passionalização, que desaceleram. Com essa estratégia, o compositor consegue maior credibilidade para a letra, ao fazer com que seu conteúdo ecoe pelas estruturas musicais.

A primeira canção encerra-se com a repetição do último verso, em fade out, ao mesmo tempo em que a segunda canção entra em fade $i n^{2}$. Esta nova canção também é um samba de roda tradicional, também anônimo, mas desta vez uma execução coletiva se opõe

\footnotetext{
${ }^{2}$ Fade é o nome dado ao processo de suavizar a entrada (fade in) ou saída (fade out) do som aumentando ou diminuindo sua intensidade progressivamente.
} 
à solidão da primeira voz acompanhada apenas pelo atabaque. Percebemos que praticamente todos os elementos desta canção se opõem à primeira. Por isso mesmo, a análise da segunda canção será contrastiva.

Podemos ouvir o prato de D. Edith, e um grupo de pessoas que compõem um coro e que palmeiam. O timbre da voz principal é diferente da primeira canção, conseqüência da diferença nas condições de gravação das duas canções. A primeira voz tem o timbre característico de uma gravação em estúdio, pois seu som é claro, preciso e bem definido, resultado típico de uma gravação feita em local fechado. Já na segunda canção, os timbres são "embolados", mal definidos, dispersos. Esta gravação foi feita certamente em local aberto, "ao vivo".

\author{
Meu aipim (Xô, piau) \\ Minha mandioca (Xô, piau) \\ Iauêêê (Xô, piau) \\ Meu aipim (Xô, piau) \\ Meu meu milho (Xô, piau) \\ Minha mandioca (Xô, piau) \\ Iauêêê̂... (Xô, piau)
}

A letra desta canção é composta apenas por pequenos versos, feitos com a junção de um pronome possessivo e um substantivo. Esses substantivos são todos vegetais típicos da culinária nordestina: aipim, mandioca e milho. Sem verbos, e sem uma narrativa explícita, esta canção nada mais é do que uma apresentação de valores. Mais do que uma 
apresentação, a insistência no pronome possessivo sugere uma verdadeira defesa desses valores. Imediatamente podemos perceber que os valores apresentados se referem ao lugar de origem, tanto do sujeito instaurado na primeira canção como deste novo sujeito. E, como vimos, trata-se exatamente dos valores ausentes no primeiro trecho.

A escolha de vegetais para representar esses valores não é casual nem irrelevante. Os vegetais extraem da terra os elementos necessários para sua vida, e nela vivem fincados até serem arrancados por uma força externa. Com essa simples estratégia, o compositor consegue apresentar de maneira muito clara os valores envolvidos nesta faixa, e de que maneira o sujeito do discurso se relaciona com esses valores. Ao remeter-se aos vegetais, que só vivem enquanto estão fincados em sua terra, ele mostra que para ele não há vida possível longe dela. Além disso, ele reitera a presença de uma força externa que atuou para afastá-lo (e como veremos, ainda atua, para mantê-lo longe). Quase como uma curiosidade, ou ainda uma "coincidência criativa", podemos ressaltar que é possível ouvir aqui a presença desta força externa, apresentada na primeira canção: a onomatopéia "iauêêêêê" pode ser facilmente aceita como o apito de um trem.

Além de estar em conjunção com os valores perdidos, nesta segunda canção o sujeito não está só como na primeira. A presença do coro, cantando e palmeando, respondendo cada verso proferido pelo sujeito, contrasta com a solidão da voz desacompanhada da primeira canção, e também com o vazio deixado pela ausência da viola no arranjo musical. O sentimento de solidão e inadequação ("eu aqui não me dou bem") são substituídos pela festa em comunidade. Desta maneira, o compositor vai agregando traços eufóricos (adequação, companheirismo, aconchego) que se opõem aos traços disfóricos apresentados na primeira canção (inadequação, solidão, saudade). É importante mais uma 
vez notar a forte insistência na marcação geográfica associada a esses sentimentos: os eufóricos estão associados ao lugar de origem, e os disfóricos, ao distanciamento desse lugar.

Esta segunda canção, em Si Maior, tem uma tessitura menor que a primeira, uma quinta justa, indo da nota Si ao Fá\#. Apesar de terem as duas canções o mesmo andamento, esta apresenta uma tendência muito mais forte (ou ainda: muito menos questionada) à tematização. A todo momento, o coro repete o refrão "xô, piau", tonema descendente finalizado pela nota da tônica, o que prende a melodia tanto à marcação rítmica dos instrumentos percussivos, quanto ao centro da tonalidade. E essa marcação rígida é ainda reforçada não só pelo atabaque, mas também pelo prato e palmas. A própria interpretação vocal também reitera os recortes rítmicos, acontecendo em períodos regulares. A recorrência deste minúsculo tema ocorre em intervalos curtos e regulares, assim como a intervenção do "proto-refrão". Todos esses elementos juntos acentuam o caráter ritualístico deste samba de roda. Tudo ocorre como se houvesse uma forte restrição à introdução de elementos novos, que poderiam desestabilizar esta rígida estrutura rítmica, harmônica e melódica.

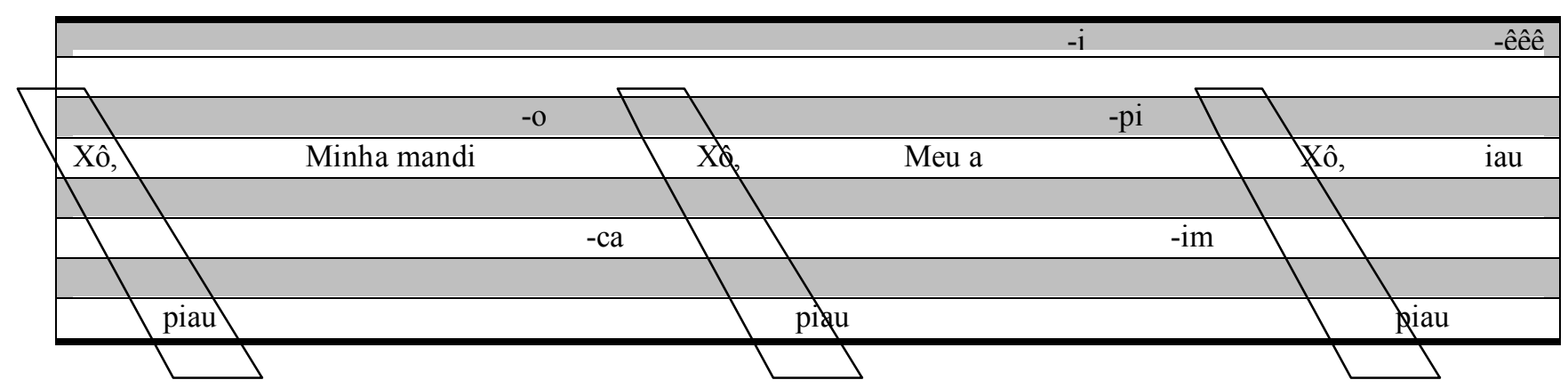


A ligação entre as duas canções é feita pelo atabaque, que as acompanha linearmente, sem rupturas. É evidente que esse atabaque foi acrescentado por meio de uma manipulação do material sonoro. A prova disso é que o atabaque não acompanha o efeito de fade in e fade out que foi utilizado para suavizar a passagem entre as duas canções. Além disso, seu timbre é o mesmo de ponta a ponta, ou seja, ele não sofreu mudança nenhuma apesar das gravações terem sido feitas em locais diferentes. Ele foi "artificialmente" colocado sobre as duas canções já prontas.

Essa manipulação é determinante para a construção da unidade desta faixa, composta por duas canções muito bem delimitadas. $\mathrm{O}$ atabaque atua para promover a continuidade entre estes dois trechos, sobressaindo como elemento contínuo em um processo de absoluta ruptura. Esse é o único elemento do segundo trecho que não se opõe ao primeiro. No primeiro trecho, o pulso constante do atabaque é um elemento relativizador, pois introduz continuidade em um contexto descontínuo. No segundo trecho, ele é um elemento intensificador. $\mathrm{O}$ atabaque, nesta faixa, atua promovendo a continuidade perdida, estabelecendo uma ponte entre a primeira parte, na qual os objetos estão ausentes, e a segunda, na qual eles estão presentes. Esta "ponte" é uma marca representativa da relação de junção entre sujeito e objeto.

Ao introduzir esse elemento contínuo, o compositor cria um efeito que determina a compreensão do sentido global desta faixa. Vimos que as duas canções delimitam dois espaços geograficamente distintos. Logo, aceitar que as duas canções foram interpretadas pelo mesmo sujeito significa aceitar que elas ocorreram em tempos distintos. Mas a presença linear do atabaque impede essa consideração. Ao manter uma pulsação constante e sem rupturas, ele delimita um espaço de tempo único, não interrompido, confrontando a 
oposição espacial a que nos referimos. Este fato desestabiliza o efeito de realismo que poderia ser produzido pela segunda canção.

O texto não nos apresenta nenhuma ação propriamente dita, capaz de fazer o sujeito vencer essa distância que separa os dois estados, mas apenas sobrepõe os dois estados do sujeito. O sujeito encontra-se em estado de disjunção (tensão?) e logo depois em estado de conjunção (resolução?). É justamente essa velocidade excessiva que cria o efeito onírico da passagem (seria impossível percorrer a distância que separa os dois espaços instantaneamente), somado ao efeito de linearidade criado pelo atabaque, que sugere que os dois estados estão acontecendo no mesmo espaço e no mesmo tempo. Cria-se a figura do sonho, da ilusão que vem aliviar a tensão da realidade. O sujeito de fato não está em conjunção real com o objeto, e ainda se encontra em estado de espera. Tudo leva a crer que a segunda situação aconteceu apenas no imaginário do sujeito instaurado pela primeira. Outro fator que apóia esta imagem é a debreagem utilizada. Ambas são enunciativas, instaurando um "eu". No entanto, enquanto o primeiro trecho instaura um "eu" "agora" e “aqui”, o segundo não menciona tempo nem espaço. Esse procedimento gera um efeito de sentido de provérbio, de verdade absoluta, que tem por função apenas a de enumerar os valores do sujeito. É a ausência de uma "âncora" temporal e espacial que "libera" esta segunda canção para que ela possa se subordinar à primeira. Uma vez que o realismo da segunda canção cai por terra, as duas imagens opostas, a dura e solitária realidade e a alegria coletiva do samba de roda, provocam um misto de sofrimento e saudade, melancolia e tristeza (blues?).

É importante também notar que o intervalo que existe entre os dois tons é de uma quarta justa ascendente. Este intervalo tem grande poder resolutivo, pois representa o 
movimento dominante/tônica. O grau dominante é o grau da tensão, da instabilidade, enquanto o grau da tônica é o grau da resolução, da estabilidade. Transpondo este conceito para a letra, temos a primeira situação, a da solidão, como expressão da instabilidade, e a segunda, a do samba de roda, de estabilidade, situação na qual se resolveriam as tensões da primeira. É importante notar que esta relação só se faz entre as notas fundamentais de cada uma das tonalidades (Fá\# e Si), pois cada trecho tem sua harmonia completa funcionando individualmente. Essa relação só pode ser percebida pelo ouvido depois de entrar o segundo trecho, quando a modulação (palavra aqui empregada no sentido estritamente musical de mudança de tonalidade) fica clara.

Dois percursos figurativos são explorados nessa canção: o do sertão e o da ferrovia. O do sertão através dos termos "viola", "sertão", "aipim", "mandioca", "milho", e o da ferrovia em "Leste", "maquinista" e "trem". O trem carrega o sentido de movimento e deslocamento. Esse deslocamento pode ser lido como um distanciamento topográfico (sertão vs cidade), mas também como um distanciamento cultural, materializando a oposição entre os valores apresentados. É esta primeira faixa que dará o parâmetro para a compreensão de todo o álbum. As oposições aqui estabelecidas serão utilizadas para compreender o sentido de cada faixa isoladamente, e também para construir o sentido global. De uma certa forma, podemos perceber o deslocamento da oposição sertão vs cidade para uma oposição do interno vs externo, ou ainda do "eu" vs "não-eu". Estas oposições, no Araçá Azul, transcendem os limites "letra/melodia/harmonia/ritmo/arranjo" impostos pela canção tradicional. A caracterização do LP como um trabalho experimental está justamente na utilização de técnicas de estúdio, como a manipulação e a sobreposição utilizadas nesta faixa, que atuam diretamente na construção do sentido de cada passagem. 


\subsection{De conversa}

A segunda faixa, "De conversa", é composta a partir da superposição de vozes trêmulas, sons guturais, percussões corporais, assovio e melodias incidentais. O caráter experimentalista a que nos referimos anteriormente é explicitado nesta faixa. Em "Viola, meu bem" observamos a justaposição de duas canções, cada qual funcionando como um sistema autônomo, e o acréscimo de sentido decorrente da justaposição de ambas. No entanto, a faixa ainda está claramente circunscrita no âmbito daquilo que é o senso comum para a definição do gênero canção: uma letra entoada sobre uma linha melódica. A experimentação da faixa anterior atuou apenas no sentido de ressaltar o elo possível entre duas canções bem delimitadas, sem no entanto questionar ou polemizar a estrutura de nenhuma delas.

$\mathrm{Na}$ faixa "De conversa", porém, a experimentação atua em um nível muito mais profundo, atingindo os elementos constituintes da canção. O procedimento empregado nessa faixa questiona os limites que separam fala e canção, o que nos obriga a uma reflexão maior sobre os fenômenos envolvidos.

A faixa começa com a interjeição "Ah", pronunciada por diversas vozes simultaneamente, cada uma estabilizada em uma nota diferente. É interessante notar que mesmo estando cada voz produzindo uma palavra de maneira "natural", plenamente identificável e aceitável como produto cotidiano da fala, a sobreposição resulta em um acorde musical. Este simples procedimento evidencia o mecanismo de produção do som, e mostra que se em um nível mais superficial o sistema de entoação da fala e o sistema musical da canção se opõem, em outro mais profundo se confundem. Evidentemente, a 
diferença entre os dois sistemas não será encontrada no nível acústico da produção do som. Isso é conseqüência direta das propriedades do som, estudadas pela física ondulatória, que prevê que não existe som que não tenha simultaneamente quatro propriedades: altura, duração, timbre e intensidade. Seja a partir de um instrumento musical qualquer, seja a partir das nossas cordas vocais, todo som tem as quatro propriedades. É tentador concluir que todo som é, em última análise, uma nota musical, mas isto implicaria em menosprezar o sentido da palavra "musical". Podemos dizer, com mais segurança, que todo som tem "potencial" para ser uma nota musical. A diferença entre o som "musical" e o som "não musical" (que denominamos simplesmente "ruído") é a sua conformidade com um determinado sistema. Este sistema varia de uma cultura para outra, e varia dentro de uma mesma cultura ao longo do tempo. Aquilo que é musical dentro de um sistema, pode ser ruído para um outro. O que nos interessa aqui é comparar o sistema musical, no qual se insere o gênero canção, e o sistema entoativo que regula o fenômeno da fala.

A principal diferença entre os dois sistemas é a importância dada à "curva melódica" traçada pelas notas relativas a cada sílaba entoada ou cantada. $\mathrm{Na}$ canção, a curva melódica é precisa e delimitada. Cada nota tem sua posição fixada em relação às outras, tendo como pano de fundo um sistema de alturas. No caso da canção, o sistema utilizado é invariavelmente o sistema tonal ${ }^{1}$. Isso implica em dizer que a melodia musical está duplamente "ancorada": cada nota se posiciona verticalmente dentro do recorte oferecido pelo sistema tonal e, horizontalmente, relaciona-se com as outras notas que compõem a melodia.

\footnotetext{
${ }^{1} \mathrm{O}$ sistema tonal é invariante em toda manifestação popular ocidental. A canção erudita contemporânea usa freqüentemente outros sistemas, como o dodecafônico, por exemplo.
} 
$\mathrm{Na}$ fala, a seqüência de notas funciona mais como um "suporte" para a transmissão da informação, sendo imediatamente descartada após cumprir sua tarefa. Essas notas não têm uma posição fixa em relação às outras, e também não estão orientadas a partir de um sistema intrinsecamente organizado. É por isso mesmo que não é comum referir-se a essas notas como uma melodia ${ }^{2}$. No entanto, este não é um suporte "passivo", isento de significação. A curva melódica da cadeia fônica transmite dados importantes sobre a situação passional do falante. Ela pode revelar o grau e o tipo de comprometimento entre aquele que fala e aquilo que é falado. A curva melódica da fala pode indicar se o texto falado é dito com intenção de verdade (afirmação) ou não (ironia), se é o resultado de uma reflexão ou se é uma indagação (pergunta), se é importante (fala exaltada) ou indiferente (fala monótona) ao falante.

Embora cada sistema, o da fala e o "cancional", funcione como sistema autônomo, as "leis" de interação entre o que é "dito/cantado" e a maneira como o texto é "dito/cantado" estão fortemente imbricadas. A canção aproveita estes movimentos da cadeia fônica da fala, para mesmo dentro de um sistema muito mais rígido, obter os mesmos efeitos de transmissão dos dados passionais do sujeito. Em maior ou menor grau, a canção pode reproduzir os mecanismos de entoação da fala, aproximando-se ou distanciando-se dela. Este fenômeno é denominado "figurativização".

É evidente que toda essa problemática não é posta em questão na fala cotidiana. $\mathrm{Na}$ primeira palavra desta faixa, no entanto, ocorre um fato que não faz parte do procedimento normal da fala cotidiana: a polifonia ${ }^{3}$. O principal fator de inteligibilidade de um texto na

\footnotetext{
2 Tatit prefere o uso do termo "cadeia fônica".

${ }^{3}$ Este termo é utilizado aqui com o sentido estritamente musical que é o de acontecimento simultâneo de notas ou frases musicais.
} 
fala é a alternância de vozes. Não treinamos, na nossa cultura, a capacidade para compreender duas ou mais vozes falando simultaneamente. Não havendo vozes sobrepostas, não há uma comparação direta "termo a termo" entre as notas de duas cadeias fônicas distintas. Ao sobrepor diversas vozes falando/cantando a palavra "ah" simultaneamente, Caetano torna esta comparação possível, e a possibilidade de estabelecer um sistema genuinamente musical a partir da fala é então evidenciada.

A faixa prossegue com a apresentação de diversas vozes "falando/cantando" a palavra "bem", ainda sobrepostas polifonicamente, mas desta vez não simultâneas. Mais uma vez, é a sobreposição o fator que permite uma comparação mais próxima entre cada evento, ressaltando o fato de que se por um lado a canção pode ser recoberta por elementos da fala (figurativização), esta também se estrutura sobre um sistema de sons musicais. Caetano apresenta dez maneiras distintas de pronunciar a palavra "bem", alterando o registro da nota entoada (grave vs agudo), a velocidade de pronúncia, e as características da curva de entoação (em direção ao grave, em direção ao agudo ou estável). ${ }^{4}$

O “coro" desorganizado de vozes é interrompido pela pronúncia da interjeição "hum" e pela palavra "mas", seguida de um breve silêncio. Já neste ponto fica evidente que o texto lingüístico desta faixa também está estruturado de uma forma não convencional, pois as palavras, quando identificáveis, não formam uma seqüência organizada, como acontece na fala cotidiana. Elas apenas estão fornecendo indícios que vão refletir nos níveis mais profundos da análise semiótica, especialmente no nível tensivo. As funções actanciais não são claramente identificáveis, o mesmo acontecendo com os atores do discurso. Tanto

\footnotetext{
${ }^{4}$ Na faixa "Quem", do LP “Tropicália 25 anos" - 1993, Caetano retoma esta experiência confrontando pronúncias da palavra "quem” extraídas de gravações de diversas músicas brasileiras.
} 
o título da faixa quanto a presença de várias vozes sugerem a idéia de uma conversa. Conseqüentemente, supõe-se a presença de duas funções actanciais, a de destinador e destinatário. Essas funções podem manter dois tipos de relação, contratual (quando se estabelece) ou polêmica (quando se dissolve). Esses dois tipos de relação deixam marcas no nível tensivo, promovendo a continuidade, no primeiro caso, ou a descontinuidade (ou parada), no segundo. É interessante notar que apesar de não haver a possibilidade de realizar uma análise prolífera no nível discursivo, os elementos presentes sugerem uma proto-narrativa, e mais ainda, apresentam as marcas do nível mais profundo da significação. Logo no início da faixa, temos uma relação contratual, na fase dos "cumprimentos": "ah", “bem". Logo depois, temos uma ruptura, com a palavra "mas", entrecortada por silêncios. Esses períodos de silêncio promovem o crescimento da tensão que a descontinuidade provoca. O compositor baiano mostra que é possível, apesar da economia absurda de signos lingüísticos, mostrar o mecanismo que rege o discurso em um nível mais profundo: contrato e polêmica, continuidade e descontinuidade. Ao introduzir um tempo de silêncio após a ruptura provocada pelo "mas", Caetano ilustra o conceito de "parada" utilizado por Zilberberg para fundamentar seu ponto de vista sobre a análise semiótica: a parada é uma ruptura que tem duração.

O silêncio é interrompido por mais uma "rodada" de vozes sobrepostas, pronunciando palavras e frases ora reconhecíveis, ora absolutamente ininteligíveis. Fica clara a intenção do compositor de direcionar o foco de atenção não para o significado do que está sendo dito (plano do conteúdo) mas para a maneira como está sendo dito (plano da expressão). Com esse procedimento, notamos que os elementos "musicais" que incidem sobre a cadeia fônica da fala não atuam exclusivamente para criar os efeitos de 
passionalização do sujeito do discurso, mas têm uma importância crucial na determinação do sotaque. Fica evidenciada a consciência do compositor sobre o fato de que o sotaque não é definido apenas pela maneira como os sons são pronunciados isoladamente (assunto tratado pela fonética), mas também pela maneira como é composta a curva melódica da cadeia fônica.

Além da polifonia vocal, neste trecho há o confronto de um tema musical, desenvolvido em gradações descendentes, apresentado por um assovio. Mais uma vez, a sobreposição de elementos nos permite fazer novas comparações entre os dois sistemas. Pela primeira vez nesta faixa os dois sistemas são apresentados simultaneamente e outro importante fator organizador do sistema melódico, ausente na fala, se faz presente: o pulso. Embora a fala possua seu ritmo, ela não chega a estabelecer um pulso regular. A escolha de determinada palavra do léxico para a construção de uma frase na fala cotidiana não leva em conta o número de sílabas, e nem tampouco o pé. O resultado é uma rítmica absolutamente aleatória, sem regularidade de acentos suficiente para o estabelecimento de um pulso constante. A questão rítmica na fala no entanto tem uma atuação de ordem intensa, atuando não sobre o sistema como um todo, mas recaindo sobre seus elementos individualmente. E este é um outro fator que atua na determinação do sotaque: a velocidade de pronúncia das palavras varia de região para região. Já na música, a rítmica tem uma função de ordem extensa, atuando sobre o sistema como um todo, dimensionando o andamento global, e outra de ordem intensa, criando e opondo células rítmicas.

É muito interessante a escolha do assovio para introduzir a primeira melodia definida da faixa. Até este momento, não houve uma apresentação de nenhum dos dois sistemas de maneira integral. As palavras desconectadas, como vimos, não caracterizam 
plenamente nenhum dos dois sistemas. O que faz diferir um sistema do outro é a organização em cadeia, ou seja, a maneira como os elementos de uma determinada seqüência interagem. Havendo uma interação melódica significativa, estamos diante de uma canção. Se, ao contrário, a interação melódica não é precisamente estabelecida, estamos diante da fala. Organizada para a compreensão lingüística a fala pode dispensar as leis musicais de ordenação. Organizada para a memorização musical, a canção independe das conexões específicas do sistema lingüístico. Pode até exibir uma letra baseada apenas na sonoridade de seus fonemas.

A terceira etapa da faixa começa justamente com a apresentação da primeira frase absolutamente inteligível:

Aí heim, na janela... você, tô lhe vendo...

Duas vozes se organizam, estabelecendo uma pulsação e alternando as palavras "por mim" e a interjeição "hum". Ao organizar-se em um pulso, a fala imediatamente deixa de ser puramente fala, e começa a ser percebida como elemento musical. Em seguida, temos a primeira manifestação de uma canção tradicional, organizada tanto musical quanto lingüisticamente:

Por onde eu moro, o tempo passa sem vapor...

A apresentação da forma canção, condensada em apenas um verso, musical e lingüisticamente organizada, após esta longa trajetória construída a partir dos elementos 
constituintes, evidencia toda a estratégia da faixa. Formalmente, é feita a proposta de que a canção tradicional é o resultado de sucessivas operações de organização feitas a partir de elementos mais simples. Trata-se de uma organização sintática que tem por finalidade não obrigatoriamente propiciar inteligibilidade, mas sobretudo garantir a preservação. $\mathrm{O}$ que está em questão é essencialmente uma organização do plano de expressão.

A "proto-canção" é entrecortada com a volta das vozes desorganizadas, e se dissolve. Com o novo ataque das vozes sobrepostas, a canção não consegue mais manter a sua estrutura interna e desaba. A resultante é um amontoado de vozes, sons guturais, notas entoadas e assoviadas, e por fim o silêncio.

Este é o final de uma primeira etapa da faixa, que deixou evidente a origem estrutural da canção, fragmentando-a, apresentando seus elementos constituintes, e a maneira como eles se organizam em cada nível de profundidade. Esta faixa mostra que a relação entre fala e canção é muito mais complexa do que a princípio poderia parecer. A estruturação que faz nascer a canção dentro da fala é constantemente ameaçada por uma força desorganizadora, como se a canção estivesse sempre por um fio, podendo a qualquer momento "voltar" a ser fala e perder seu poder de preservação. O equilíbrio entre essas duas forças é dinâmico e tenso. Por essa razão, Tatit já comparou o processo de composição cancional à arte dos malabares: o compositor precisa sempre equilibrar simultaneamente as forças de organização do sistema musical e de desorganização do sistema entoativo. Mais do que isso, o bom compositor consegue esse equilíbrio com tal graça que todo o esforço para conseguí-lo - assim como o malabarista - permanece desapercebido. ${ }^{5} \mathrm{Na}$ "De

\footnotetext{
${ }^{5}$ Cf. TATIT, 1996
} 
conversa", a estratégia empregada foi justamente a de trazer essa problemática para o primeiro plano.

Na segunda etapa, as vozes trêmulas e os sons continuam. Uma voz canta uma seqüência de notas, nítida citação do tema "Assim falou Zarathustra", de Richard Strauss, imortalizado no filme "2001 - Uma odisséia no espaço", de Stanley Kubrick, lançado em 1968. Esta pequena melodia possui características muito interessantes. Partindo de uma nota fundamental, a melodia alcança uma quinta justa e posteriormente uma oitava. Estas duas notas são os dois primeiros harmônicos da série harmônica. Elas são portanto desdobramentos da nota fundamental. Há um aspecto de exploração da origem física do som nesta seqüência de notas. Mais interessante ainda é o fato de que essas notas, apesar de estabelecerem um ponto de origem com a fundamental, não são suficientes para a definição tonal maior ou menor ${ }^{6}$. Elas formam portanto um "embrião" que pode se desenvolver em dois sentidos distintos. E Strauss, ao invés de realizar a escolha e polarizar a música para uma das duas tonalidades, enfatiza a ambigüidade, apresentando logo em seguida as duas terças do acorde: a maior e a menor.

A referência à obra prima de Kubrick também não é casual. O roteiro do filme, baseado em um conto de Arthur C. Clarke e elaborado a quatro mãos pelo autor e pelo cineasta, narra a trajetória da espécie humana, desde sua origem primata, até um determinado ponto no futuro. A presença de um objeto externo, o "monolito", simboliza a evolução do homem primitivo ao Homo Sapiens. Ele marca o ponto de partida, ou origem, da nossa espécie. O restante da narrativa é a busca desse objeto, ou seja, a busca desse símbolo primordial, a busca da origem da espécie humana. Trata-se não de uma origem

\footnotetext{
${ }^{6} \mathrm{O}$ tom maior ou menor é definido pela qualidade do intervalo de terça.
} 
biológica, mas principalmente da "condição humana", da origem do raciocínio característico da espécie humana. A inserção desta citação neste ponto do álbum é um reforçador para a isotopia da busca dos valores de origem, constante em toda a obra.

Em seguida, o som das palmas surdas se organiza, estabilizando um pulso. Uma voz se estabiliza como principal, imitando o som anasalado dos repentistas nordestinos. Esta é a maneira como se dá a actorialização nesta faixa. O reconhecimento de determinado sujeito só é possível graças às características sonoras de sua fala. Esta voz principal logo se desestabiliza, assim como o ritmo criado pelas palmas. Então um novo ator é apresentado, com vozes imitando um aboio. Por um instante, todas as vozes se organizam, criando uma célula rítmica que se repete por alguns instantes e se dissolve.

Ouve-se uma voz, imitando criança, dizendo "Tô com fome" algumas vezes. A idéia de fome é reforçada também nos créditos da música, que informa que a percussão é feita sobre a pele e ossos. Na realidade, é impossível a percussão exclusivamente sobre pele e ossos, pois ao se percutir sobre o corpo, ele todo ressoa, e não só a pele e os ossos. Pele e osso é a expressão usada para designar um corpo muito magro, o que reforça a idéia de fome. Esse regime de escassez, simbolizado pela fome, ecoa pelo arranjo, através dos sons curtos e secos das palmas surdas. Há uma forte ênfase na ruptura e na descontinuidade neste trecho da canção, acentuando os valores remissivos. Existe uma união muito clara entre a idéia de fome e escassez e a imagem do nordestino do sertão, imagem nitidamente reconhecível no repentista, ao qual Caetano também faz alusão. E assim como aconteceu em um nível estrutural mais profundo, na "De conversa", o repentista também se aproveita de motes básicos que organiza para criar sua música. 
Surge um terceiro ator, também apenas identificável pelo sotaque. A voz do fundo, que estava cantarolando, começa a organizar progressivamente uma pequena seqüência de notas, que serão utilizadas na música que se forma logo após, com as vozes inferiores se estabilizando numa linha de baixo. Ouvem-se também percussões corporais e um coro que entra no segundo verso da voz principal. O coro canta apenas com vogais e, sem o efeito percussivo das consoantes, e assume um caráter etéreo e melodioso. Desta maneira, há uma ênfase na continuidade neste trecho da canção. Este fato novo opõe-se nitidamente ao trecho anterior, passando a realçar os valores emissivos, fazendo com que a entrada da canção simbolize o fim da escassez. A música é "Cravo e canela", de Milton Nascimento e Ronaldo Bastos, indicada nos créditos entre aspas. No quarto verso, a voz se antecipa ao coro, provocando um efeito de "eco". Mais vozes entram, defasadas, e surge um piano acompanhando a polifonia.

\author{
$\hat{\mathrm{E}}$, morena, quem temperou, \\ cigana quem temperou, o cheiro do cravo \\ $\hat{\mathrm{E}}$, cigana quem temperou, \\ morena quem temperou, a cor de canela
}

A letra de "Cravo e canela" também questiona a origem e o mecanismo da criação. O cantor pergunta à morena "quem temperou o cheiro do cravo", ou seja, quem fez o cravo, ou quem fez o cravo ter o seu cheiro característico. A mesma pergunta ele faz a respeito da canela, buscando a origem das coisas comuns. E essa pergunta é direcionada à morena, que tem a cor do cravo e da canela, fazendo com que o cantor acredite ter ela as respostas. A 
morena, então, assume o papel de destinador, a quem o destinatário recorre, buscando o saber. É ela que representa os valores apresentados, o "cravo" e a "canela". A "De conversa" também está procurando a origem do comum, do cotidiano, procurando a origem da fala e do canto. Também está procurando a origem negra da nossa música. Temos aqui um sujeito em busca do valor modal do /saber/.

$\mathrm{O}$ andamento rápido e a pulsação periódica da canção evidenciam a modalidade do /fazer/ presente no processo de tematização. O pequeno tema que inicia com um salto intervalar e encerra com um tonema descendente é repetido três vezes em cada estrofe. A presença do movimento disjunto de ordem intensa acentua a tensão da curva melódica. É importante ressaltar também a presença de um elemento figurativo, o tonema ascendente em "temperou”, que ocorre nas duas estrofes.

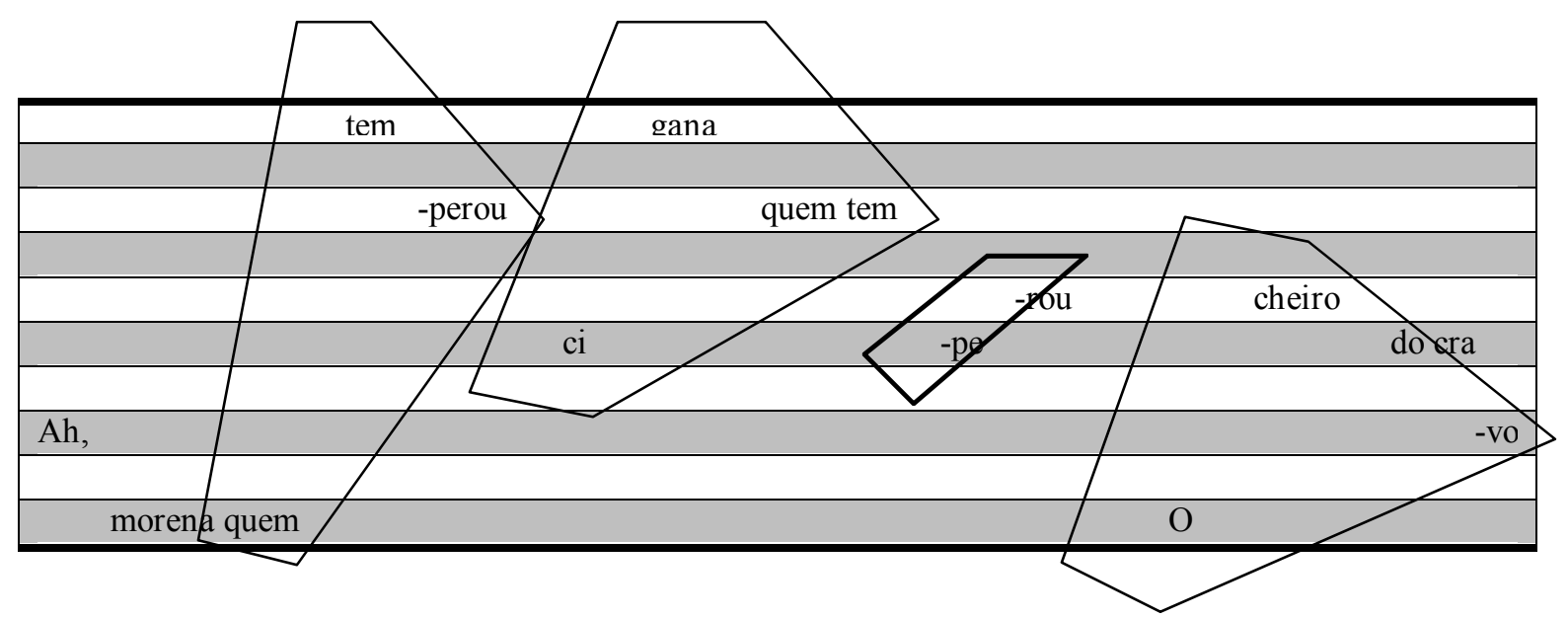




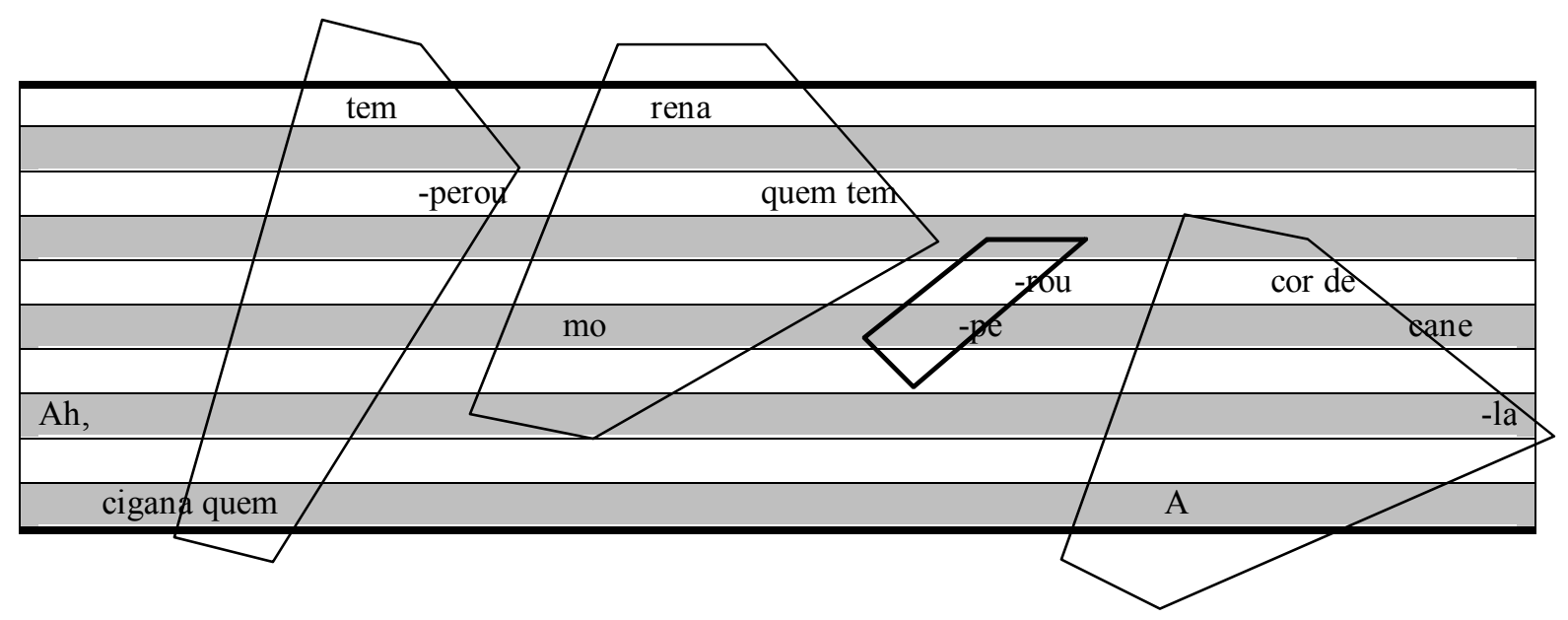

Depois da citação musical, o tema da canção se fragmenta progressivamente, juntando-se novamente à fala desordenada e a grunhidos (experimenta-se a nítida sensação de que eles estiveram sempre lá). A desorganização da fala desestrutura a música, dissolvendo-a. Ouve-se clara a frase:

Eu quero ver você alegre

Em seguida, os próprios versos se fragmentam, o coro se fragmenta, a percussão se fragmenta. O piano esboça a melodia, incompleta. Ao fim, a frase clara e precisa:

\section{É conversando que a gente se entende}

Tanto no $A h$ inicial como no entende final, todas as vozes falam simultaneamente, fechando-se então um ciclo. 
Há uma importante diferença no procedimento desta segunda faixa em relação à primeira. Vimos, na análise de "Viola, meu bem" que é nítida a manipulação do som em estúdio, fator que caracteriza o experimentalismo deste trabalho. No entanto, a manipulação se deu no sentido de ressaltar as possibilidades de sentido resultantes da sobreposição de duas canções absolutamente intactas. Não há ali um questionamento sobre a estrutura da canção, nem nenhum fator que possa contribuir para a descaracterização de algum dos trechos enquanto canção. Já na "De conversa", como acabamos de ver, a canção é algo que ocorre como conseqüência direta da manipulação dos elementos constituintes, completamente fragmentados. Há uma clara ruptura com o procedimento da faixa anterior, e também com a maneira convencional de composição. Esse sentido de ruptura não seria tão eficaz se esta faixa fosse a primeira do LP. Há uma intencionalidade clara no sentido de conduzir a expectativa do enunciatário/ouvinte, levando-o a aceitar contratos que serão constantemente quebrados.

Uma das grandes contribuições da semiótica para a análise do discurso é entender o texto ao mesmo tempo como objeto de significação e objeto de comunicação. Desta forma, da mesma maneira que dentro do texto podemos encontrar destinadores, destinatários e objetos em circulação, o próprio fazer enunciativo é um fazer passível de análise. O enunciador também é um destinador, que pode assumir com o enunciatário contratos fiduciários. Esta dupla acepção do texto dá ao modelo semiótico uma grande flexibilidade, pois com as mesmas ferramentas de análise é possível dar conta do texto em si, e das diversas relações entre enunciador e enunciatário.

É impossível compreender o impacto do lançamento do LP Araçá Azul sem contextualizá-lo com a trajetória de seu compositor/enunciador. Ao reunir suas informações 
biográficas, declarações na mídia, e obras anteriores, que também não passam de textos, poderemos compor a imagem de um ator/destinador/enunciador, produtor de textos, que não se confunde com a pessoa Caetano Veloso. O fato é que, mesmo no auge da fase tropicalista, Caetano era visto e conhecido principalmente graças às suas canções. O LP Tropicália - Panis et circenses, apesar de representar uma enorme revolução estética, é um disco de canções. Todos os discos anteriores de Caetano, incluindo a fase no exílio em Londres, são discos de canções. Até mesmo os happenings tropicalistas aconteciam sob o mote de canções, e Caetano havia deixado o Brasil após um estrondoso sucesso: a canção “Alegria, alegria”. Todos esses fatores bastam para aceitar que seus enunciatários/ouvintes acreditavam ter firmado com o enunciador/compositor um contrato, reiterado em todos os seus gestos, de que este seria um compositor de canções. A expectativa que circulava sobre o Araçá Azul era de como seriam as canções, mas nunca se seriam canções. Ao apresentar ao seu público a anti-canção, a canção fragmentada e desmistificada, Caetano provoca a ruptura deste simulacro. Essa ruptura foi grande o suficiente para provocar reações generalizadas de vingança.

A reação do público foi veemente: o disco bateu recordes de devolução. Transa tinha tido uma boa acolhida (sobretudo por causa da regravação do velho samba de Monsueto Menezes "Mora na Filosofia") e o fato de eu estar de volta ao Brasil ainda era notícia. Além disso, eu fizera um show ao lado de Chico Buarque no Teatro Castro Alves, em Salvador, com imenso sucesso, e esse show (uma comoção resultante do esforço amadorístico de um conhecido comum a nós dois, ampliada pela suposta rivalidade) foi transformado num disco ao vivo que vendeu muito. Tudo isso levava as pessoas a procurarem meu disco novo nas lojas. Ao chegar em casa, a maioria nem sequer agüentava ouvir a primeira faixa até o fim: voltava correndo ao vendedor para tentar devolver o disco. ${ }^{7}$

\footnotetext{
${ }^{7}$ VELOSO, 1997. pp. 486-487.
} 
Podemos então entender a faixa "De conversa" como uma dupla ruptura: a primeira em relação ao modo habitual de composição de seu enunciador; a segunda em relação à própria seqüência do LP.

Segundo Caetano Veloso, em seu Verdade Tropical, o título "De conversa" também referencia João Gilberto, que tinha acabado de gravar o samba "De conversa em conversa". ${ }^{8}$ A citação de João Gilberto, de uma certa maneira, sustenta os procedimentos utilizados nessa faixa. João Gilberto é considerado o "grau zero" da música popular brasileira. Sua interpretação vocal deriva diretamente da fala, ou melhor, sua interpretação ressalta a fala que existe por trás da canção. Essa faixa pode ser entendida como a radicalização, ou ainda a experimentação sobre seu procedimento musical. Além disso, ele foi a figura central da bossa-nova, movimento que representa um marco em nossa música, ao sincretizar a origem afro-européia com a modernidade harmônica do jazz norteamericano. Para muitos, inclusive para o próprio Caetano Veloso, ele representa o "elo perdido" entre o passado musical brasileiro e sua modernidade. Dessa forma, sua citação reforça a idéia de continuidade, de uma "linha evolutiva", ligando valores primordiais (relacionados à origem) aos valores novos. Dentro da ruptura que representa esta faixa, o compositor sugere a possibilidade de uma sutura, em outro plano, com os valores representativos da música (e da cultura brasileira).

A mesma função tem a citação feita de Milton Nascimento ao utilizar a sua "Cravo e canela" como música incidental. Mais uma vez, dentro da ruptura, o compositor consegue restabelecer laços com os valores que, para ele, realmente importam. De uma certa forma,

\footnotetext{
${ }^{8}$ Ibid. p. 485.
} 
há uma desvalorização da estética experimental enquanto técnica em si, pois ela é colocada a serviço dos valores de origem. Fazer música experimental, sob esta ótica, seria uma maneira de discutir e repensar a música brasileira. Ao afirmar que a frase "Eu quero ver você alegre" se destinava diretamente a Milton Nascimento, como uma "[...] oração para que ele superasse aquela tristeza imensa que o prostrava $[\ldots .$.$] ", surge uma mensagem com$ características ufanistas. Esse aspecto ufanista já despontava por trás das críticas presentes em outras composições tropicalistas.

[...] eu não era inocente ao fato de que toda paródia de patriotismo é uma forma de patriotismo assim mesmo - não eu, o tropicalista, aquele que antes ama o que satiriza, e não satiriza facilmente o que odeia. ${ }^{9}$

${ }^{9}$ Ibid. p. 338. 


\subsection{Tu me acostumbraste}

A inclusão da canção "Tu me acostumbraste" abre uma nova dimensão para o leque de significados até então explorados no LP. Esta canção é um grande sucesso do compositor cubano Frank Dominguez, e é interpretada em espanhol por Caetano, acompanhada por violão, um assovio constante e poucas notas de piano, no registro agudo. Esta é a terceira vez em que Caetano grava uma canção do repertório hispano-americano a primeira tinha sido "Las Tres Carabelas", de A. Algueró e G. Moreu, gravado no LP Tropicália em 1969, interpretado junto com Gilberto Gil e alternando trechos em castelhano e em português, extraídos da versão de João de Barro desta mesma canção. Ainda em 1969, ele grava no LP Caetano a faixa "Cambalache”, de E. S. Discépolo. Este é apenas o começo de uma prática que se tornaria constante na obra do compositor baiano, e que culminaria com o lançamento do álbum Fina Estampa, em 1994, integralmente dedicado a este repertório.

\begin{tabular}{|c|c|c|c|c|}
\hline Álbum & Ano & Canção & Compositor & Nacionalidade \\
\hline Tropicália & 1969 & Las três Carabelas (As três & A. Algueró / G. & Espanha \\
& & caravelas) & Moreu / versão: João & \\
& & & de Barro & Argentina \\
\hline Caetano & 1969 & Cambalache & E. S. Discépolo & Cuba \\
\hline Araçá Azul & 1973 & Tu me acostumbraste & Frank Dominguez & Cuba \\
\hline Qualquer Coisa & 1975 & Drume Negrinha & Eliseo Grenet / versão: & \\
\hline
\end{tabular}




\begin{tabular}{|c|c|c|c|c|}
\hline Qualquer Coisa & 1975 & La flor de la canela & Chabuca granda & Peru \\
\hline Maria Bethânia e & 1978 & Meu primeiro amor (Lehania) & H. Gimenez / versão: & \\
Caetano Veloso & & & J. Fortuna / & \\
& & & Pinherinho Jr. & \\
\hline Totalmente & 1986 & Cuesta abajo & Carlos Gardel / & Argentina \\
demais & & & Alfredo le pera & \\
\hline Circuladô - ao & 1992 & Mano a mano & Carlos Gardel / José & Argentina \\
vivo & & & Razzano / Esteban & \\
& & & Celedonio Flores & \\
\hline
\end{tabular}

É muito clara na obra de Caetano a tendência a explorar uma possível "identidade cancional latino-americana". A sua interpretação tende sempre a suavizar as diferenças e ressaltar as semelhanças entre as canções da América espanhola e as canções brasileiras. Este procedimento será analisado em maior profundidade mais adiante, especificamente no caso de "Tu me acostumbraste".

Até este ponto, o LP Araçá Azul apresentou uma canção manipulada em estúdio ("Viola, meu bem") e uma faixa explicitamente experimentalista ("De conversa"). A presença de um bolero, canção de estrutura formal, cantada em língua espanhola, provoca mais um grande choque na seqüência do disco. A intensidade desse choque é ainda maior devido à ausência de uma introdução musical para a canção: ela já inicia no primeiro verso. Fica muito claro aqui um procedimento que viria a ser "marca registrada" do fazer musical de Caetano Veloso, que é a ruptura de "proto-contratos" entre enunciador e enunciatário. 
Como já vimos anteriormente, a relação enunciador-enunciatário é vista pela semiótica como uma relação semelhante à relação destinador-destinatário, mediada por contratos. A inclusão de uma faixa experimental representou uma ruptura com a expectativa dos enunciatários já em relação com o enunciador/ator Caetano Veloso. Mas, internamente, esta obra também está propondo um novo contrato, que está sendo manifestado na capa, encartes, e sobretudo no material musical. Ao apresentar este bolero, há uma aparente ruptura interna deste contrato. O que acontece na realidade é uma velocidade muito acelerada no fluxo de informações. Há um salto muito rápido entre procedimentos semióticos muito distintos, o que dificulta a apreensão e a ligação do sujeito (no caso, o enunciatário) com o objeto.

É interessante perceber que se por um lado há uma ruptura na seqüência linear do disco, em outro nível, Caetano promove uma sutura. Caetano canta o bolero com uma voz leve e suave, aos moldes de João Gilberto, opondo-se à tradicional força que os cantores do gênero costumam empregar em suas interpretações. O resultado desta sobreposição é justamente o estreitamento entre o fazer musical da América espanhola e o brasileiro. Trata-se de um refinadíssimo jogo de reavaliações de conceitos e preconceitos sobre a canção. Há uma revalorização tanto do bolero, tipicamente tachado como gênero "brega" no Brasil, quanto do poder modernizante da interpretação vocal de João Gilberto. Esta oposição entre brega e moderno foi freqüentemente empregada nas composições, arranjos e roteiros dos happenings tropicalistas.

Na segunda apresentação do tema, executada uma oitava acima da primeira, percebe-se um choque entre a leveza do falsete e uma certa aspereza no timbre da voz, provocada em estúdio pela adição de uma leve distorção. 
[...a canção] "Tu me acostumbraste" ganhava uma interpretação em duas oitavas, com a segunda rodada cantada em falsete, como Ray Charles em "People", só que com uma precária distorção eletrônica adicionada. ${ }^{1}$

Mesmo dentro dos limites de um período aparentemente "não experimental", que é o que parece constituir esta faixa, essa artificialização da voz faz a ponte entre o contexto experimental e o não-experimental. Fica claro que a intenção não é opor estes dois procedimentos, e mostrar as suas diferenças, mas sobretudo trançá-los, e mostrar as suas semelhanças. A evidenciação de uma técnica de estúdio em uma canção formal traz a tona o momento e o ambiente da produção deste texto auditivo, sendo portanto uma genuína marca do momento da enunciação. Graças a esse elemento, há uma marca no texto que se refere ao espaço de produção do mesmo, sendo este portanto um processo de ancoragem. É evidente que não há nenhuma diferença entre o ambiente de produção desta ou de qualquer outra canção gravada industrialmente, mas a presença desta marca no texto faz com que a “ilusão de realidade” provocada pela reprodução sonora desapareça. Há um efeito de distanciamento do cantor/narrador instaurado no texto, ao mesmo tempo em que se desloca a atenção para o momento de produção do texto (enunciação).

Uma série de conseqüências importantes decorrem deste procedimento. Ao desviar a atenção para a oposição natural vs artificial dentro de uma canção, Caetano aponta com grande clareza para o paradoxo entre produto cultural e produto industrial. Há uma reafirmação (do óbvio) de que toda canção gravada é sempre um produto industrial, sempre

\footnotetext{
${ }^{1}$ Veloso, 1997. p. 486.
} 
manipulada em estúdio. Mas, pelo menos até este ponto da nossa análise, não é possível perceber uma sobremodalização (eufórica ou disfórica) realizada sobre esta constatação.

A aceitação desta manipulação do material sonoro como sendo uma marca da enunciação sobre o texto produzido deixa entrever um verdadeiro campo aberto de possibilidades para a pesquisa semiótica na canção. Estamos diante de um fato tradicionalmente ligado ao nível discursivo, que são os efeitos de sentido gerado por marcas da enunciação. No entanto, a pesquisa atual ainda não se debruçou sobre a canção para fazer uma análise mais detalhada neste nível do percurso gerativo, atendo-se sobretudo aos níveis mais profundos do percurso.

Vamos prosseguir nossa análise com o estudo da letra da canção:

Tu me acostumbraste

A todas esas cosas

E tu me enseñaste

Que son maravillosas

Sutil,

llegaste a mi como una tentación

llenando de inquietud

Mi corazón 
Yo no concebía

Como se quería

En tu mundo raro

Y por ti aprendí

Por eso me pregunto

Al ver que me olvidaste

Por que no me enseñaste

Como se vive sin ti

Neste texto as funções actanciais são nítidas. O destinador "tu" determina os valores ("todas essas cosas", "tu me enseñaste que son maravillosas") e doa ao destinatário "eu” os valores modais do /querer fazer/ e /saber fazer/ ("llenando de inquietud", "Yo no concebia como se queria", "Y por ti aprendi"). Fica explícito também que a manipulação se deu através da tentação ("llegaste a mi como una tentación”). Há um sincretismo actancial, pois o mesmo ator "tu" recobre as funções de destinador e objeto, e o ator "yo" as de destinatário e sujeito. Na última estrofe, há uma ruptura de contrato entre o destinador "tu" e o destinatário "yo", ao mesmo tempo em que finda a conjunção entre sujeito e objeto. O destinatário se questiona por que o destinador não o ensinou a viver sem este contrato. Semioticamente, isso significaria ter o destinador em si mesmo, ou seja, sincretizado com o destinatário no mesmo ator "yo". Essa busca por um novo destinador que doaria o /saber fazer/ viver já poderia ser notada na reflexividade da pergunta (“por eso me pregunto"). 
A debreagem enunciativa provoca o efeito de sentido de aproximação e subjetivação. Isso realça o caráter passional da canção. É possível observar dois percursos temáticos, o da conjunção e o da disjunção amorosa. O primeiro manifesta-se em "tu me acostumbraste", "me enseñaste”, “maravillosas", "tentación”, “por ti aprendí"; o segundo em "legando de inquietud", "Yo no concebia", "me pregunto", "olvidaste", "no me enseñaste".

Mais uma vez, o texto apresenta um sujeito em estado de espera, em situação de disjunção. O elemento novo é que desta vez não se trata de valores primordiais, ligados à origem do sujeito. Ao contrário, esses valores foram adquiridos (ou melhor, tornaram-se valores) progressivamente, mediante a ação de um destinador ("tu me acostumbraste", "tu me enseñaste"), até o ponto em que eles se tornaram imprescindíveis ("como se vive sin ti"). Esse é um tipo de disjunção diferente daquele trabalhado na primeira faixa. Em "Viola, meu bem" fica clara a oposição entre origem e presente, a primeira eufórica. Apesar de estar em disjunção com os valores eufóricos, estes estão claramente definidos e localizados, caracterizando a noção de sentido. Já no estado final de "Tu me acostumbraste", o sujeito está modalizado pelo /querer ser/ conjunto, ou seja, possui o sentimento de falta, mas não sabe mais exatamente onde estão os valores ausentes. A busca final do sujeito não é simplesmente a volta da relação rompida. Sua busca agora é da própria identidade. Ao mesmo tempo em que o sujeito sabe não poder mais voltar ao estado inicial (/saber-nãopoder-ser/), antes da modalização exercida pelo destinador, ele ainda não sabe ao certo quais valores buscar agora. Ele está perdido, em busca de um /saber ser/ ("por que no me enseñaste"). O efeito de sentido obtido é exatamente o de ausência de sentido. 
$\mathrm{O}$ andamento lento e a inexistência de uma marcação rítmica forte refletem a escolha de um projeto entoativo marcado pela desaceleração. É um ambiente propício para a manifestação da modalidade do /ser/, de estados passionais. Esse projeto resulta numa melodia que privilegia o percurso, que valoriza as durações e amplia a tessitura. De fato, toda a interpretação está marcada pelo prolongamento das vogais. Podemos perceber, em toda a primeira parte, movimentos conjuntos tanto de ordem intensa (graus imediatos) como de ordem extensa (gradação):

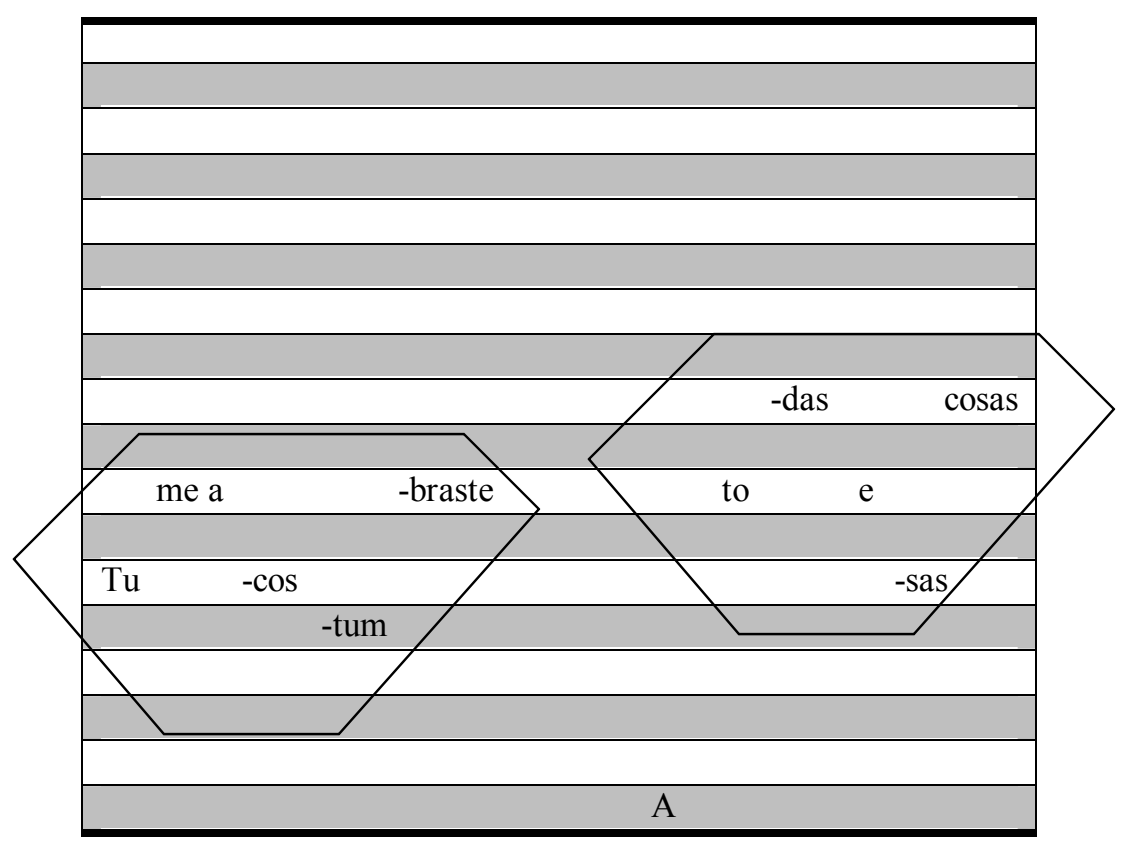




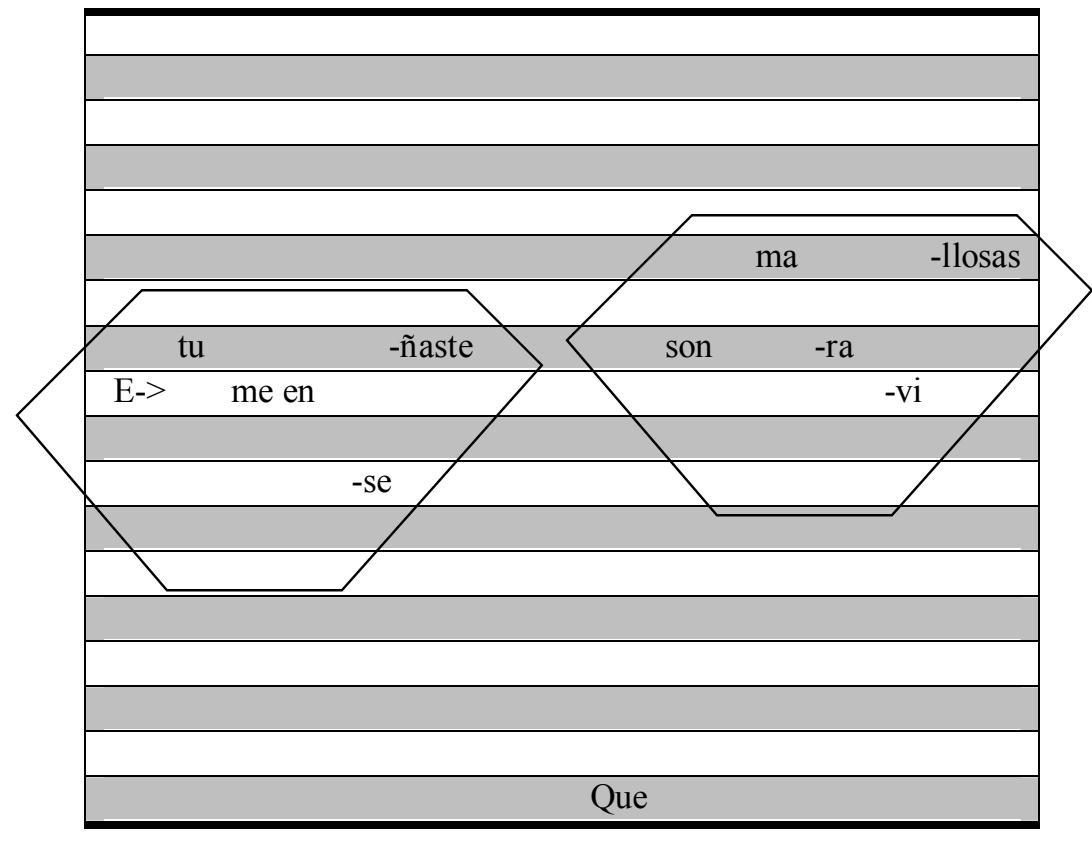

Podemos perceber também a inclusão de dois saltos intervalares, partindo do extremo grave, que conferem um pouco de velocidade (surpresa) à desaceleração provocada pelo uso excessivo de movimentos conjuntos. A gradação segue um padrão ascendente, havendo portanto um pequeno acréscimo de tensão em cada módulo. Esse acréscimo atinge seu ápice na segunda parte, quando a melodia chega no extremo agudo, exatamente com o adjetivo que qualifica o fazer persuasivo do destinador: "sutil". Essa segunda parte alterna o uso de graus imediatos e saltos intervalares, ressaltando mais uma vez a situação passional do sujeito: 


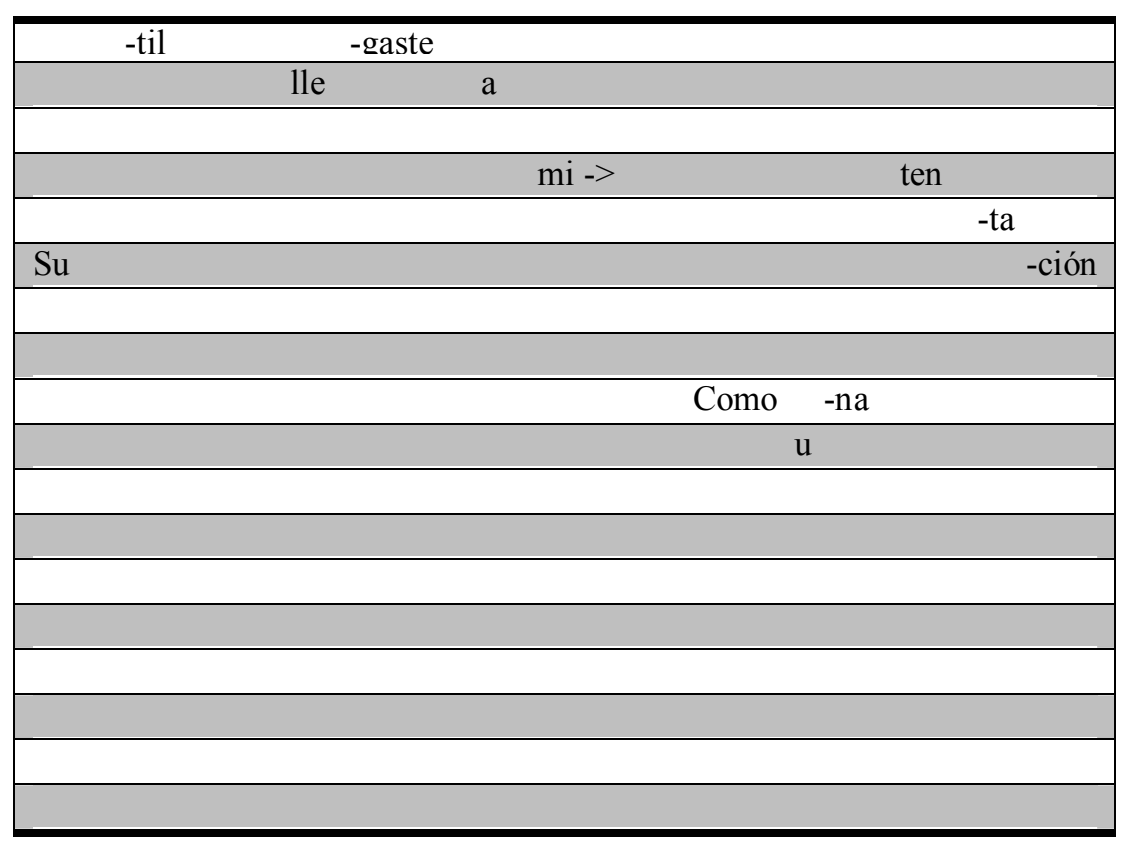

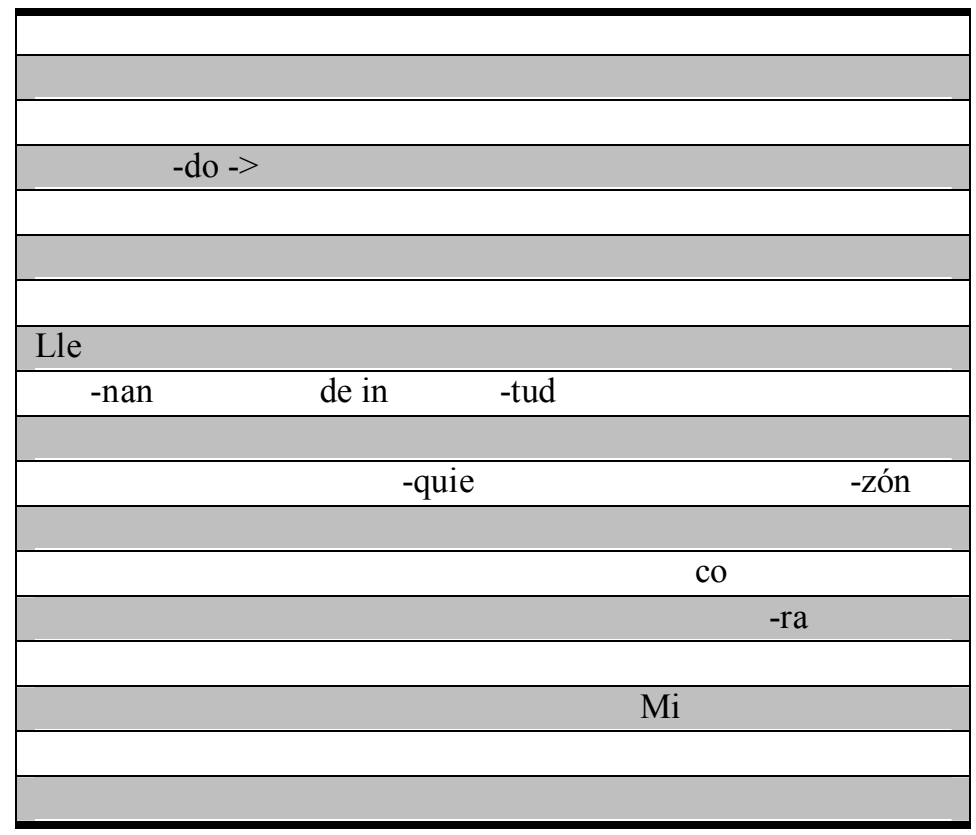


A terceira parte é a repetição do primeiro tema melódico, em gradações ascendentes:

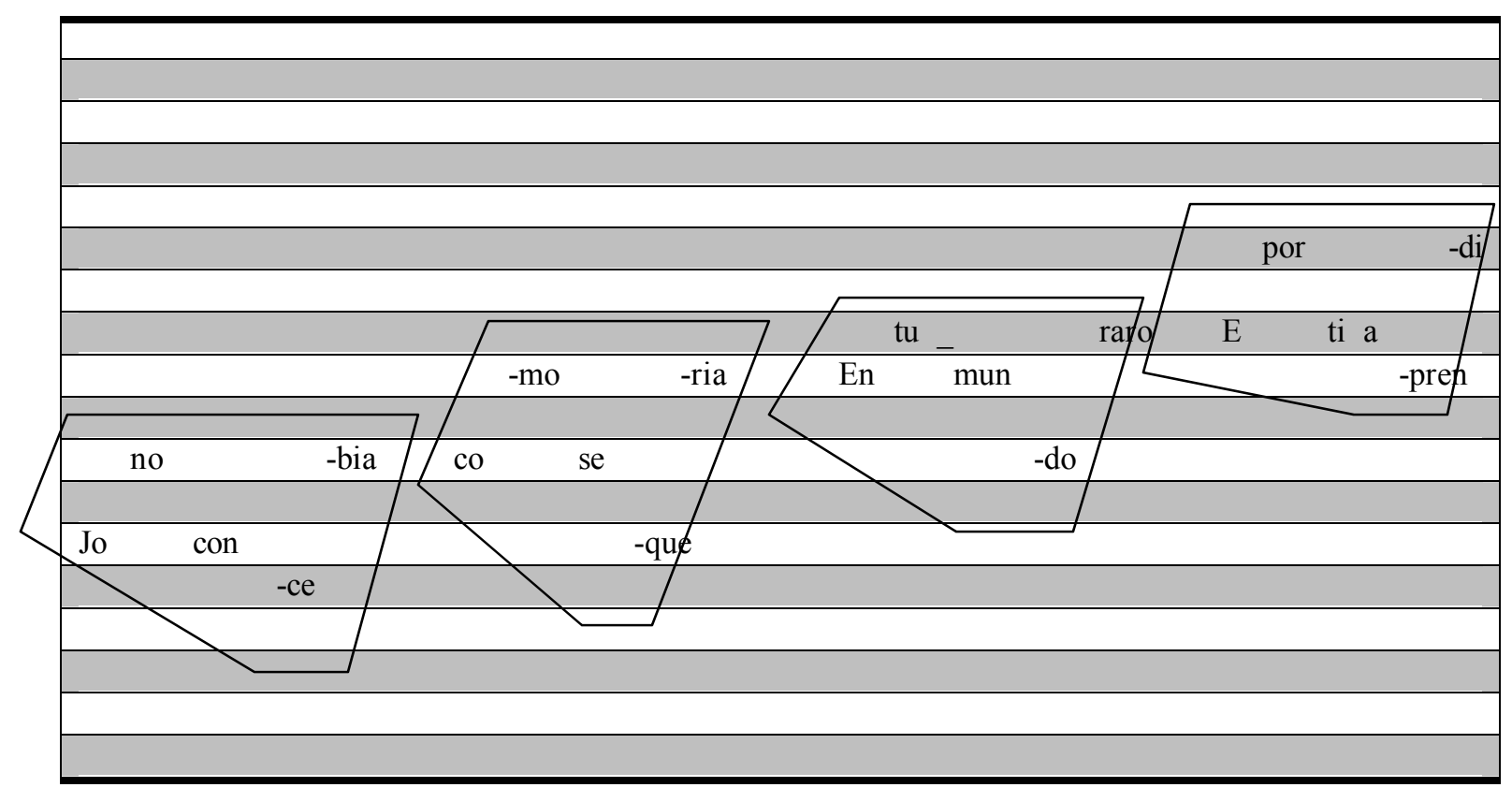


O uso excessivo de gradações é comum em canções desaceleradas. De certa forma, esta é parte da "estratégia" do sujeito para reter o objeto por mais tempo, retendo o próprio tempo. Como que prevendo a inevitável disjunção final, o sujeito retarda a evolução da tensividade (note a direção ascendente da seqüência de gradações), postergando o colapso. Este vem em seguida, com a exposição do tema final no extremo agudo:

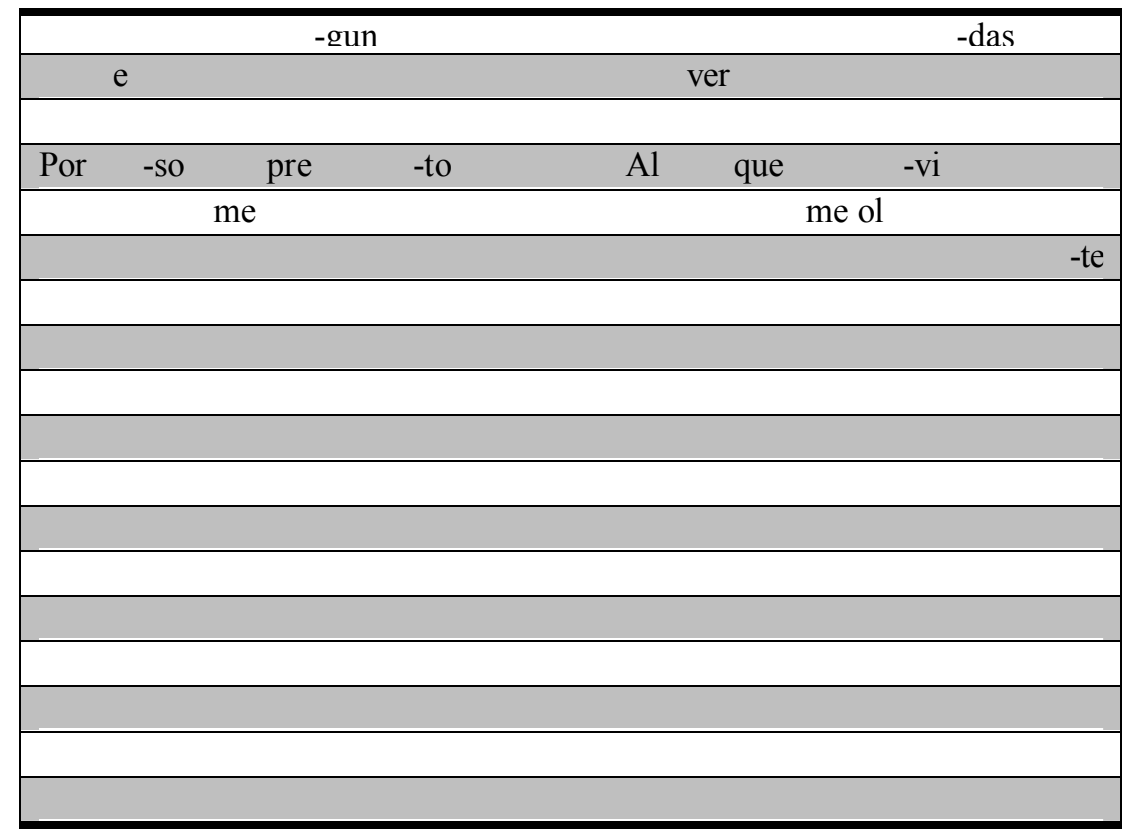


A tensão gerada neste trecho é dissipada na melodia descendente "por que no me enseñaste", que assume o caráter de um "desabafo", e é retomada pela melodia ascendente “como se vive”. Esta é a pergunta que resume todo o plano do conteúdo lingüístico. Sua posição estratégica lhe confere um grande teor de tensão passional: ela é colocada logo após uma melodia descendente que praticamente atravessa toda a tessitura; ela parte do extremo grave e desenha uma curva ascendente. A resolução dessa tensão se dá com o retorno à tônica, em um tonema descendente.

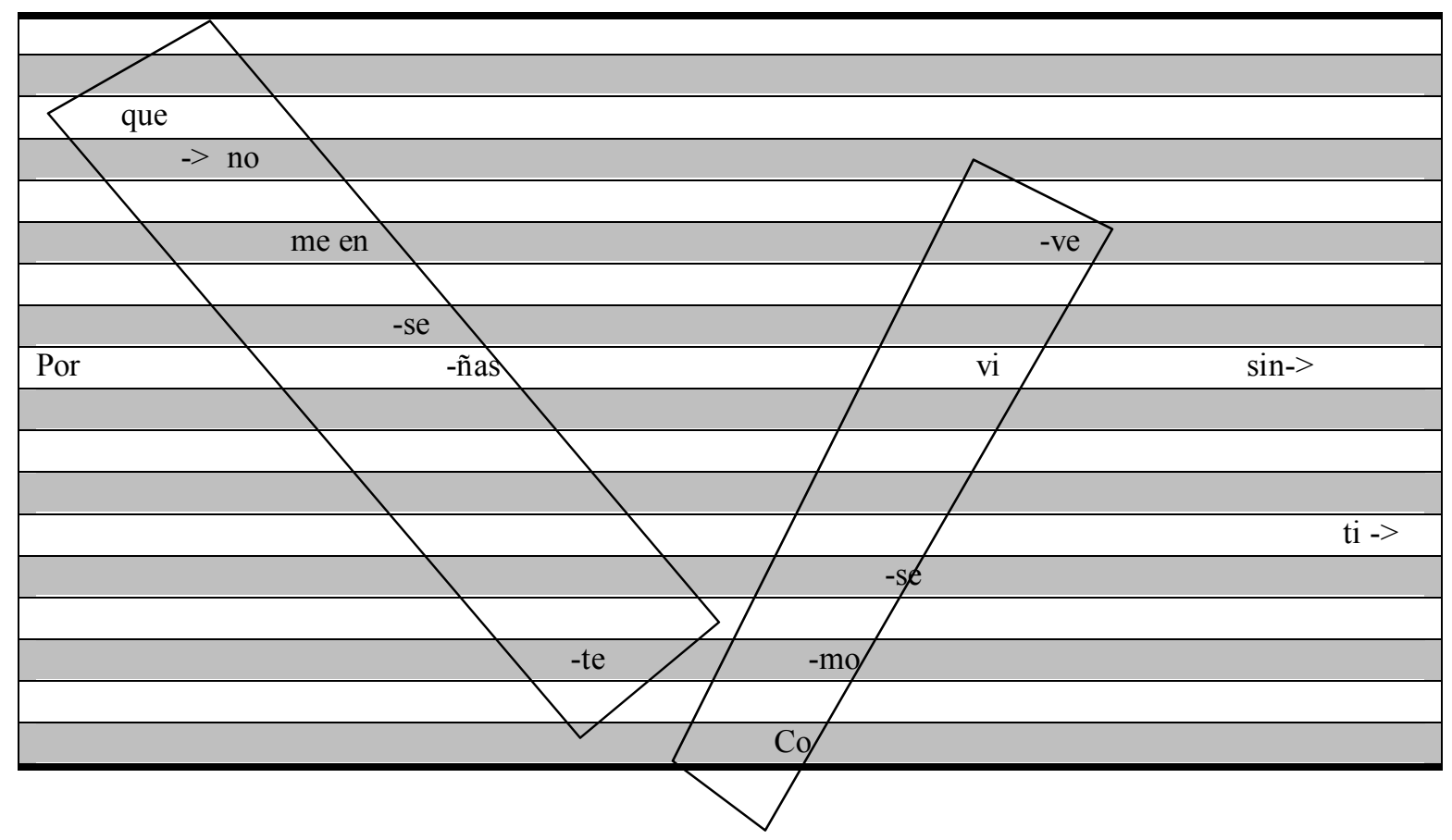

A segunda exposição do tema aumenta ainda mais o conteúdo passional do texto melódico devido à transposição oitava acima. Essa leveza, ressaltada pelo emprego do 
falsete nas notas agudas, fragiliza a imagem do "eu lírico" da canção, mostrando mais nitidamente a dor causada pelo abandono descrito na letra.

Há uma ressonância entre esta canção e a citação do compositor cubano Bola de Nieve, no encarte central. É interessante a insistência em menções à Cuba em um contexto que questiona a identidade e a perda de identidade. Cuba é o ícone de resistência à dominação política e cultural estrangeira, sobretudo norte-americana. Essa referência traz com muita força, para a nossa "aquarela" de significados colhidos a cada faixa do LP, a oposição entre liberdade e opressão.

A partir desses dados já coletados, começa a ser possível perceber um alinhamento entre as oposições estabelecidas nas três primeiras faixas do LP e no material visual da capa e dos encartes. Esses dados podem ser visualizados na tabela 2:

\begin{tabular}{|c|c|}
\hline Liberdade & Opressão \\
\hline Identidade & Perda de identidade \\
\hline Valores de origem & Valores externos \\
\hline Natural & Artificial \\
\hline Sertão & Cidade \\
\hline
\end{tabular}

Tabela 2 


\subsection{Gilberto Misterioso}

A quarta faixa do LP, "Gilberto misterioso", começa com a apresentação de um acorde ao violão (Sol Maior) e uma voz, entoando a nota Sol, registro agudo, nota longa, dizendo a palavra "sol”. A voz realiza então um rápido portamento ${ }^{1}$ descendente até chegar em Ré, acompanhada pelo breve ataque do acorde D7(9) (Ré com sétima e nona), dominante de Sol. O violão realiza um arpejo neste mesmo acorde, até o retorno da notapalavra Sol. Neste momento, o violão passa a tocar a nota Fá. Não há nenhuma marcação de pulso: tudo transcorre absolutamente $a d l i b^{2}$. Enquanto sustenta a nota sobre a palavra “sol”, a voz procura explorar as possibilidades de variação na emissão do som, tanto do ponto de vista fonético (variando a abertura da vogal “o”), quanto musical (mudando sutilmente a afinação da nota). Tudo é feito de maneira a não descaracterizar nem o fonema nem a nota musical. Aparentemente, o intérprete está buscando a essência do som emitido, tateando os limites dos sistemas, mostrando a "folga" existente entre uma nota e outra, entre um fonema e outro ${ }^{3}$. As notas Sol (da voz) e Fá (do violão) caracterizam o acorde G7 (Sol com sétima), dominante de Dó, tonalidade do segundo movimento da faixa:

gil em gendra

em gil rouxinol

\footnotetext{
${ }^{1} \mathrm{O}$ termo portamento é usado para designar a transição suave e contínua entre uma nota e outra.

2 ad lib é o mesmo que ad libitum: sem pulsação determinada

${ }^{3}$ Em música, esta "folga" é representada pelos "comas". O sistema ocidental estipula o semitom como menor intervalo entre as notas, mas o ouvido humano consegue diferenciar até nove espaços diferentes dentro deste intervalo. Este espaço é denominado "coma".
} 
Este verso é definido nos créditos do encarte central como "o verso misterioso de Souzândrade". Ele está na $72^{\mathrm{a}}$ estrofe do Canto X do poema longo Guesa. A grafia do original difere um pouco da citação transcrita no encarte interno do álbum:

Gil-engendra em gil rouxinol

O verso é cantado doze vezes, e se organiza em pares. O primeiro descreve melodicamente uma parábola com a concavidade para cima, provocando sentido resolutivo, potencializado pelo fato de a melodia acabar em Dó - e este ser ao mesmo tempo a tônica do trecho e o ponto mais baixo da tessitura. O segundo verso é um espelhamento do primeiro, uma parábola com a concavidade para baixo, com sentido suspensivo.

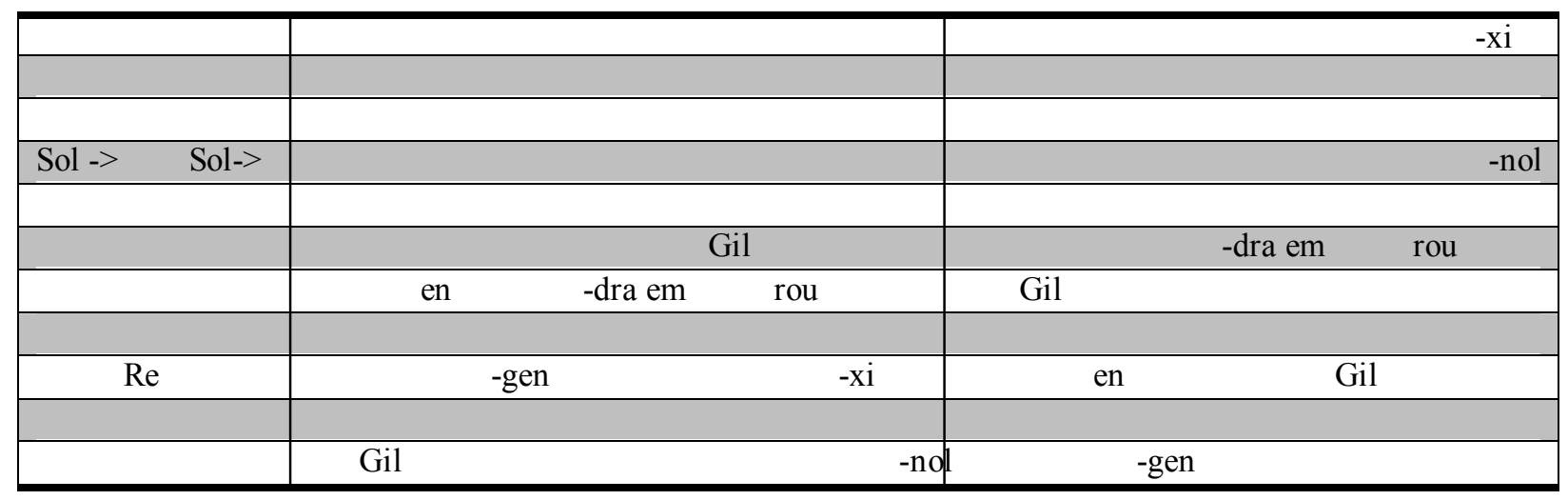

A harmonia também contribui para a construção do sentido da frase melódica neste trecho. Os dois versos são acompanhados pelos mesmos acordes, dispostos de maneira diferente. 


$\begin{array}{lllll}\text { 1 }^{\circ} \text { verso: } & \mathrm{C} 7(9) & \mathrm{G} 7 & \mathrm{Bb} 7(9) & \mathrm{F} 7 \\ 2^{\text {o verso: }} & \mathrm{C} 7(9) & \mathrm{F} 7 & \mathrm{Bb} 7(9) & \mathrm{G} 7\end{array}$

Todos os acordes são de estrutura dominante (acorde com sétima). Esse tipo de harmonização é freqüente em Blues mas também em alguns estilos de música nordestina, em especial o Baião. No primeiro verso, temos a finalização em F7 (Fá com sétima), acorde de função subdominante: ele não oferece repouso harmônico, mas também não apresenta um alto grau de tensão. Já o segundo verso termina com G7 (Sol com sétima), acorde dominante (tenso) que prepara o retorno da seqüência em Dó. A melodia termina na fundamental deste acorde, nota sol. Esse fato, somado à ascendência da curva melódica, dilui o aspecto conclusivo do tonema descendente: temos aqui um ponto de tensão que espera resolução.

Este trecho tem o pulso bem marcado pelo violão e percussão, em ritmo de marcha, com destaque para o triângulo. O andamento é moderado: 130 BPM (batimentos por minuto). Após uma pausa, a voz retoma cantando o mesmo verso 14 vezes, uma oitava acima, com o andamento acelerado para 180 BPM. A percussão é resumida a um tambor, que marca fortemente a entrada de cada compasso.

O terceiro movimento é ao mesmo tempo um desdobramento do primeiro, e uma retomada de alguns aspectos da segunda faixa, "De conversa em conversa". O violão e o piano apresentam diversas vezes o semitom formado pelas notas Si e Si bemol, tanto harmonicamente quanto melodicamente ${ }^{4}$.

\footnotetext{
${ }^{4}$ Um intervalo harmônico é formado por notas atacadas simultaneamente. Já o intervalo melódico é composto por notas soando sucessivamente.
} 
A voz passeia livremente pelas mesmas notas, explorando os comas, assim como no início da faixa, só que desta vez a amplitude deste "passeio" é maior. Na primeira parte, havia um deslocamento suave em torno de um único ponto (uma nota). Agora, a voz se desloca de uma nota para outra. Sutilmente, o intérprete está tentando testar os limites entre um vibrato e um desafino, no primeiro caso, e entre um portamento e uma valorização dos comas. O fator que determina estes limites, em última análise, é o da velocidade de execução: quando rápida (plano intenso), a freqüência do vibrato não chega a colocar em xeque a posição da nota-alvo. Da mesma maneira, o portamento rápido transpõe claramente o degrau de uma nota a outra. Ao desacelerar a execução, temos uma valorização do percurso (plano extenso) capaz de anular tanto a percepção da nota-alvo no vibrato, como os degraus do portamento.

Faz-se necessário tecer algumas considerações sobre os sistemas musicais envolvidos nesses processos. Teoricamente, a gama de alturas possíveis corresponde ao conjunto de números reais: entre um ponto e outro, infinitas divisões são possíveis. O ouvido humano realiza um recorte, que está relacionado com a sua capacidade física de discernir sons de alturas diferentes: são os comas. Por sua vez, o sistema temperado realiza um outro recorte, que divide a oitava em doze partes iguais: os semitons. Trata-se da escala cromática. Finalmente, temos o recorte da escala, que dentro do sistema tonal escolhe sete dentre as doze notas para estabelecer um eixo de orientação - é o que chamamos de tonalidade. Uma vez estabelecido um sistema, que em última análise é definido pelo recorte escolhido, qualquer inclusão de elementos de outro sistema é um fator de desestabilização.

Outras vozes entram cantando frases ininteligíveis, e emitindo ruídos e grunhidos. O piano passa a arpejar o acorde C7 (Dó com sétima), formado pelas notas Dó, Mi e Sib, no 
entanto sem deixar de insistir na nota Si. O fato notável é que Si é sétima maior de Dó, incompatível com Sib, sétima menor. Dentro desse contexto, o choque entre essas notas é enorme. Mais do que um simples choque melódico, Caetano consegue com esse procedimento colocar em xeque todo o sistema que rege a harmonia da música popular. Esta parece ser a função primordial desta faixa: questionar os sistemas. Os dois pilares da música ocidental são revistos: a divisão da escala em doze notas (sistema temperado) e a organização dos acordes (sistema tonal).

No final deste terceiro movimento, as vozes se organizam ritmicamente (exatamente como na segunda faixa), preparando o retorno do trecho cantado. Desta vez, só é cantado o primeiro verso - o segundo é apresentado pelo piano, com um dobramento de assovio. Há um breve fade out, e depois mais um retorno, com o acompanhamento do atabaque (mais uma ligação, desta vez com a primeira faixa). Esta faixa é essencial para construir a unidade do LP, justamente por retomar alguns elementos, procedimentos e timbres anteriormente explorados. Além disso, como veremos mais adiante, ela antecipa muito do material que será explorado nas faixas subseqüentes.

No início da faixa, Caetano realiza uma operação que em música recebe o nome de solfejo: entoar as notas dizendo o seu nome. Ao alterar a afinação das notas entoadas, ele está "friccionando" o sistema metalingüístico usado para nomear essas notas e o sistema musical no qual elas estão inseridas. O que deveria ser, no sistema temperado, uma relação exata e inequívoca, passa a ser um território de livre de experimentação. É um processo de liberação e, ao mesmo tempo, de desestabilização.

O "verso misterioso" surge como uma imensa força estabilizadora. Aqui temos uma melodia e harmonia absolutamente tonal, e um ritmo fortemente marcado: tudo se opõe ao 
primeiro movimento. No entanto, a seqüência lógica pergunta/resposta dentro desta segunda parte está invertida. A primeira frase tem sentido conclusivo (resposta), e a segunda, suspensivo (pergunta). A resposta vem antes da pergunta. Nesta passagem Caetano mostra, sutilmente, a enorme e poderosa interação existente entre texto e melodia na canção, já que uma mesma frase assume significados opostos apenas com uma pequena mudança da linha melódica. Esse efeito é ainda maior com a inversão da seqüência lógica. A mesma frase, no seu estado suspensivo, questiona o poder de afirmação da primeira frase, resolutiva.

Engendrar, verbo transitivo direto, é definido como "formar, gerar, produzir", ou ainda "engenhar, inventar". O verbo assume então a forma de um /fazer ser/. O sujeito operador "Gil" transforma (/fazer/) o seu próprio estado (/ser/). O termo "rouxinol" remete ao cantar e, metonimicamente, à canção, à criação musical. A pessoa Gil cria, em si mesma, o cantor/músico/compositor Gil. Esse /fazer/ é marcado pelo andamento rápido e o ritmo bem definido da melodia da segunda parte.

É muito interessante a replicação do mesmo procedimento semiótico em aspectos diferentes do mesmo texto. Há neste experimento uma sintonia muito fina entre o que é dito (lingüisticamente) e como isto está sendo dito (melodicamente). Temos uma melodia que em um momento afirma, e em outro questiona, formando um sistema de engates sem fim. O mesmo acontece no texto lingüístico: "Gil engendra em Gill. Este mesmo movimento também aparece no plano da expressão do texto lingüístico, com a aliteração do som das consoantes $[z]$ e $\left[\int\right]$ e a repetição da vogal i. Todos os elementos apontam para a construção sincrética da figura de uma máquina a vapor, com suas engrenagens em 
movimento contínuo. Este efeito também pode ser associado ao som de um trem em movimento, compondo assim um elo com a primeira canção do álbum.

Nesta construção, temos três repetições da fricativa palatal sonora [ z ] em "gil", "engendra" e "gil", seguida de uma fricativa palatal surda [ ] em "rouxinol". A confrontação entre essas consoantes é ainda maior devido à periodicidade rítmica: elas estão nas sílabas que recaem sobre os tempos fortes da melodia. Essa periodicidade foi artificialmente colocada pela harmonização do poema: o resultado auditivo provém de um erro de prosódia em "rouxinol" que, com o deslocamento da sílaba tônica, passa a ser ouvido "rouxínol". Simetricamente dispostas, o traço diferencial entre as duas consoantes (sonoro vs surdo) fica ressaltado. Essa bela construção poética tem eco no plano do conteúdo, já que a transformação operada pelo sujeito, como vimos, é justamente um fazer musical (simbolizado pelo rouxinol).

Há nesta faixa uma grande insistência em confrontar elementos muito próximos, valorizando a busca do traço distintivo. No primeiro movimento, o intérprete parte de uma nota e testa seus parâmetros, mudando a afinação. Ao mesmo tempo, ele procura outras possibilidades para a emissão do fonema que carrega a nota entoada. No terceiro movimento, ele usa duas notas contíguas mas harmonicamente incompatíveis, e explora o espaço existente entre elas. No segundo movimento, temos uma harmonia de quatro acordes iguais em ordem diferente, alterando o direcionamento da tensão harmônica. Paralelamente, uma melodia simétrica, que provoca efeito resolutivo em um primeiro momento, e suspensivo no segundo. No plano lingüístico, a sucessão de três consoantes iguais e uma quarta que difere em apenas um traço. Temos também uma mudança na própria descrição do título da faixa: no selo do disco e no encarte central a faixa é intitulada 
"Gilberto Misterioso"; no encarte interno, temos "Gil Misterioso" (ao analisar a letra da canção, é possível concluir que o acréscimo de sentido é dado pela forma “Gilberto”). É interessante a relação entre os procedimentos desta faixa e a análise da musicalidade da poesia de Sousândrade, feita pelos irmãos Campos:

A arte sonora sousandradina responde a um conceito aberto de musicalidade, que tanto pode incluir uma calculada alquimia de vogais e consoantes, num sentido de harmonização pré-simbolista, de "poesia pura", como incorporar a dissonância e o contraste, o choque e a aspereza. É uma arte que não se volta apenas para o acorde, mas se deixa torturar até a ruptura ou a explosão pelo sentimento do desacorde. ${ }^{5}$

Ao invés de apontar para a solução das tensões que foram levantadas, o compositor prefere deixá-las ressoando, embaralhadas, sem uma resolução definida. A busca inicial da essência do som dá lugar a uma constelação de significados decorrentes da ambigüidade da construção proposta. Ao estabelecer a metáfora da máquina a vapor, concomitantemente com o gesto de cantar, Caetano faz ainda surgir a oposição entre o fazer mecânico, dessemantizado, e o fazer criativo, sem no entanto apontar euforicamente para nenhum dos dois. A euforização se dá sobre o próprio eixo estabelecido, e não sobre os pólos. Mais do que uma sanção, o compositor atua no sentido de apresentar as informações. Assim como em “Tu me acostumbraste”, Caetano mostra mais uma vez o paradoxo criação/produto, condição de existência de uma canção gravada em uma mídia industrial.

Há também uma tensão entre as duas "fases" da faixa. A primeira, identificada como a busca da essência do som, é executada com total liberdade rítmica. Ela é marcada

\footnotetext{
${ }^{5}$ CAMPOS, Augusto de; CAMPOS, Haroldo de. Revisão de Sousândrade. 2. ed. Rio de Janeiro: Nova Fronteira, 1982. p. 80.
} 
pelo regime da desaceleração, conseqüência da ausência de pulso. Ao contrário, a segunda etapa é concebida sob o regime de aceleração, com o pulso rápido e definido. A abrupta interrupção da primeira parte com a entrada da segunda também provoca um efeito ambíguo. Ao mesmo tempo em que fica evidente o poder organizador do pulso acelerado, competente para engendrar o /fazer/, há uma opressão sobre a liberdade divagante do /ser/, manifestado na primeira etapa. Mais uma vez não há dados suficientes para estabelecer um sentido para o eixo, deixando claro que a intenção não é a de julgar, mas simplesmente fazer ver. O autor claramente não pretende "resolver" o mistério citado no título da faixa: ele quer apenas valorizá-lo.

A primeira referência clara é a do cantor e compositor Gilberto Gil. Junto com Caetano Veloso, Gil protagonizou o movimento tropicalista do início ao fim. Ele é parceiro de Caetano em três faixas do LP Tropicália, Panis et circenses, e tem uma parceria com Torquato Neto e outra com Capinam. Ele pode ser considerado o "fundador" do tropicalismo, na medida em que foi a partir de suas idéias que o movimento começou a ser traçado. Neste LP, há uma outra referência direta a Gil na segunda faixa: no meio das vozes sobrepostas, pode-se ouvir: "Gilberto Gil eu gosto pra caramba". A presença de Gilberto Gil amplia o quadro de personagens oriundos do movimento tropicalista, "Arnaldo dos Mutantes" (citados no encarte, faixa 5), e Rogério Duprat (arranjador da faixa 9).

A referência ao poeta maranhense Souzândrade abre um amplo campo discursivo. Nascido a 9 de julho de 1832, Sousândrade antecipou em várias décadas recursos poéticos que só seriam sistematicamente explorados a partir do modernismo. Em seus poemas, podemos observar o uso de estrutura não-linear, discurso polifônico, neologismos, alegorizações, onomatopéias, linguagem sincrética, entre outros. Em Revisão de 
Sousândrade, obra pioneira no movimento de resgate da memória do poeta maranhense, os irmãos Haroldo e Augusto de Campos realizam uma profunda análise da obra sousandradina, ressaltando suas principais características:

Trata-se, realmente, de uma linguagem que apresenta níveis estilísticos vários, uma linguagem sincrética por excelência, abrindo-se num verdadeiro feixe de dicções, que tanto vai se alimentar nos clássicos da língua, quanto se projeta em invenções premonitórias do futuro da poesia. ${ }^{6}$

As personagens - como as máscaras poundianas - assumem a iniciativa do discurso. E se interpelam. E se interpolam. Tudo é matéria dialogada: travessões simples ou duplos, em quase todas as estrofes, assinalam as falas das dramatis personae. [...]. É um teatro minimizado, caleidoscópico, onde tudo cambia vertiginosamente como num fantástico palco giratório. ${ }^{7}$

Surpreendentemente, algumas das análises encontradas na obra dos poetas paulistas parecem descrever exatamente algumas passagens deste LP. A polifonia "caleidoscópica" de vozes que se sobrepõem em "De conversa" é apenas um pequeno exemplo dentro dos imensos paralelos que irão se constituir nas demais faixas. $\mathrm{Na}$ "Gilberto misterioso", o primeiro elo construído pelo compositor pode ser definido pela expressão empregada na análise que transcrevemos: "tudo cambia". Aqui, todos os elementos que constituem o texto estão em vibração: notas, fonemas, sistemas de escalas, tonalismo, ritmo, harmonia, melodia - nem o título da canção escapa à força transformadora que atua nesta faixa.

Há uma importante ligação entre o foco temático do Araçá Azul e do Guesa de Souzândrade. O Guesa é um poema longo, com mais de treze mil versos e composto de

\footnotetext{
${ }^{6}$ Ibid. p. 26.
}

${ }^{7}$ Ibid. p. 56 
treze cantos. É a obra prima de Sousândrade: a ele o poeta dedicou cerca de trinta anos de sua vida.

O guesa - cujo nome significa errante, sem lar - era uma criança roubada aos pais e destinada a cumprir o destino mítico de Bochica, deus do sol. Educavam-no no templo da divindade até os 10 anos de idade, quando deveria repetir as peregrinações do deus, culminando com o percurso da "estrada do Suna" e o sacrifício ritual, aos 15 anos [...]; no plano histórico e social, assimila a esse destino o do selvagem americano, o ameríndio, sacrificado pelo conquistador branco. [...] o novo guesa, hipostasiando seu destino nos povos aborígenes da América destruídos ou colonizados pelo europeu, transfere seu inconformismo para uma cosmovisão reformadora, na qual propõe uma hierarquia de valores, como perspectiva de uma nova civilização americana. [...] De um lado, condenava as formas de opressão e de corrupção, profligando o colonialismo e satirizando as classes dominantes (a nobreza e o clero); de outro, preconizava o modelo republicano, grecoincaico, colhido na República social utópica de Platão e no sistema comunitário dos Incas, ou ainda numa livre interpretação das raízes do cristianismo. ${ }^{8}$

Há um alinhamento entre a trajetória do guesa e da personagem descrita na primeira faixa do LP. Afastados do seu lugar de origem, ambos enfrentam o choque entre os valores primitivos e os valores alheios - sempre manifestados como uma opressão. Em "Épico", nona faixa deste LP, este afastamento também se transformará, assim como na obra de Sousândrade, na consumação de um destino - evidentemente, um destino épico. No entanto, em Araçá Azul os movimentos de afastamento e opressão não são tão violentos como no guesa. A fuga dos valores de origem não é violentamente imposta como uma condição vital (o guesa é arrancado dos pais). Ao contrário, aqui tudo parece ocorrer melancolicamente.

\footnotetext{
${ }^{8}$ Ibid. pp. $40-41$.
} 
A pesquisadora Luiza Lobo, em seu Épica e modernidade em Sousândrade, traz à luz algumas informações importantes para a nossa análise:

O modelo romântico de Sousândrade foi, sem dúvida, a mescla brasileira de Byron - o grande ídolo dos nossos românticos - e Gonçalves Dias, [...] iniciador do indianismo. Seria inevitável que tal ideal híbrido secionasse o personagem guesa [...] em duas facetas: a de herói romântico, envolto em uma trama épica, política, idealista, [...] e a do herói indígena, buscando salvaguardar seus valores em meio a uma crescente destruição causada pelo colonizador europeu. ${ }^{9}$

A originalidade de Sousândrade está [...] em não se prender a um perfil já consagrado pelo indianismo brasileiro, [...] mas sim buscando ampliar suas fronteiras para um perfil sul-americano, colando-o ao índio peruano (inca) e colombiano (muisca, em que o Guesa é a criança a ser sacrificada). Assim, opta por uma defesa do índio em nível mais amplo e simbólico, mostrando-o como um povo submetido ou extinto pela civilização européia mais forte. ${ }^{10}$

Como vimos na análise de "Tu me acostumbraste", este parece ser um projeto maior dentro da obra de Caetano Veloso. Já aqui neste LP, não faltam indicativos: o canto em espanhol, a citação do cantor cubano Bola de Nieve e o compositor Frank Domingues. Mais uma vez, no entanto, a consolidação de uma unidade sul-americana na obra de Caetano se dá de maneira mais doce e menos violenta do que no guesa.

O canto X, de onde foi extraído o verso entoado em "Gilberto misterioso", foi rebatizado pelos irmãos Campos de "Inferno de Wall-Street"11. Este trata da supremacia da Bolsa de Valores na escala de valores do homem moderno e do confronto entre civilizações colonizadoras e colonizadas. Analisando a estrofe na qual o verso aparece, podemos

\footnotetext{
${ }^{9}$ LOBO, Luiza. Épica e modernidade em Souzândrade. Sao Paulo: Presença/Edusp, 1986. p. 12.

${ }^{10}$ Ibid. p. 12.

${ }^{11}$ CAMPOS, 1982. p. 11.
} 
perceber que as semelhanças entre a obra do poeta maranhense e o LP Araçá Azul não param por aí:

(W. Childs, A. M. elegiando sobre o filho de SARAH-STEVENS:)

- Por sobre o fraco a morte esvoaça...

Chicago em chamma, em chamma Boston,

De amor Hell-Gate é estrafrol...

Que John Caracol,

Chuva e sol

Gil-engendra em gil rouxinol...

Civilização... ão! ... Court-hall!

As obras Revisão de Sousândrade e Lecture de l'enfer de Gérard de Cortanze, fornecem algumas pistas para a compreensão da estrofe em questão:

BOSTON: 72/2: Alusão ao incêndio de Boston, em 1872 [...]

CHICAGO EM CHAMMA: 72/2: em outubro de 1871, dos dias 8 a 11, grande incêndio destruiu o centro de Chicago; perdas estimadas em 196.000 dólares

CHILDS, W: 72: George William Childs, 1829-1894, filantropo e editor norte-americano. Lançou, em Filadélfia, o Public Ledger (1864-94), que se tornou um dos primeiros jornais de preço acessível nos E.U.A., com ampla circulação $[\ldots]^{12}$

STEVENS, SARAH (72) : peut-être une allusion à John Stevens (1749-7838) industriel américain qui participa à l'essor des chemins de fer et de la navigation a vapeur. ${ }^{13}$

A utilização de estradas de ferro para simbolizar o voraz avanço industrial é um tema que percorre todo o poema. Alguns trechos são dedicados a descrever greves e revoltas - muitas delas violentas. Paralelamente, temos no LP a versão "doce" da ferrovia,

\footnotetext{
${ }^{12}$ CAMPOS, 1982. pp. 334-350.
} 
que mantém o sujeito afastado em "Viola, meu bem", e que compõe a paisagem musical/visual descrita em "Sugar cane fields forever". A degradação dos centros urbanos aqui explosiva, na forma de incêndios - surge de forma menos contundente, na poluição de “Épico".

Também não escaparam do crivo sousandradino as influências externas que o poeta maranhense recebeu ao longo de sua trajetória. Contrário ao procedimento usual da sua época, Sousândrade não se lançou ao nacionalismo exacerbado, que na "defesa" dos valores nacionais pouco fazia além de copiar fórmulas consagradas pelas correntes literárias européias. Seu trabalho já era, na segunda metade do século dezenove, essencialmente antropofágico.

Este inusitado e importante fato também foi salientado por Luiza Lobo:

[...] a importância e a originalidade de Sousândrade estão no fato de possuir excepcional capacidade de absorver os escritores estrangeiros, seus contemporâneos ou do passado, e reintegrá-los num todo autônomo. ${ }^{14}$

Sousândrade foi contra-ideológico, na medida em que aceitou a influência estrangeira e pôde agir contra ela de dentro de um conceito de nacionalidade próprio [...]. Jamais se preocupava com o problema da nacionalidade, no sentido estreito do termo, enquanto nacionalismo temático. Ao contrário, era na mescla de culturas que encontrava o que era especificamente nosso. ${ }^{15}$

Sousândrade talvez tenha sido o primeiro autor brasileiro a perceber a importância da síntese de influências estrangeiras na literatura nacional. Esta percepção se tornaria, no

\footnotetext{
${ }^{13}$ CORTANZE, Gérard de. Lecture de l'enfer. In: . O inferno de Wall-Street. Paris: Éditions Seghers, 1981. p. 151

${ }^{14}$ LOBO, 1986. p. 13.

${ }^{15}$ Ibid. p. 14 .
} 
Manifesto pau-brasil, de 1924, e no Manifesto antropófago, de 1928, um dos requisitos básicos: deglutir o estrangeiro e metamorfoseá-lo. ${ }^{16}$

Em Araçá Azul, a antropofagia se manifesta não só através das letras mas também na instrumentação, nos arranjos, nos ritmos. Essa questão foi crucial num dado momento da história da música brasileira, quase quatro décadas depois da semana de arte moderna de 22. Avesso à polarização estilística que provocou uma cisão na MPB, gerando dois movimentos distintos e rivais (nacionalistas extremados e roqueiros assumidos), Caetano preferiu a mescla, propondo uma revisão do fazer musical no Brasil, sugerindo a possibilidade de fazer música genuinamente brasileira utilizando guitarras elétricas. O Araçá Azul evidencia essa proposta em diversas passagens, como na apresentação do samba de Monsueto em forma de rock'n'roll, o samba-de-roda na faixa "Sugar cane fields forever" (alusão aos Beatles), ou mesmo a inclusão da "Tu me acostumbraste".

Neste contexto, a presença de Sousândrade em Araçá Azul fecha um arco de quase um século dentro da cultura brasileira. É no mínimo surpreendente a constatação de que os mesmos procedimentos conseguiram provocar rupturas profundas (e reações adversas) em momentos tão distintos. A "explosão tropicalista" é na verdade a terceira grande manifestação do discurso antropofágico no Brasil. É interessante notar também que, por ser este LP uma obra ao menos cronologicamente "pós-tropicalista", esta inclusão tem um

\footnotetext{
${ }^{16}$ Ibid. p. 14.
} 
certo teor "didático". Apesar de toda a faixa versar sobre a valorização do mistério, a citação explícita a Sousândrade não deixa de ser um desvelar. 


\subsection{De palavra em palavra}

A quinta faixa, "De palavra em palavra", inicia com as palavras "som", no agudo, e “mar”, no grave. Essa última palavra termina com uma respiração, manipulada com o efeito de reverberação. O reverb, como é conhecido, é responsável pela composição espacial da cena musical. Além dos canais esquerdo e direito, que permitem perceber a posição da fonte sonora, o reverb atua na percepção da profundidade da fonte, ou seja, a distância aparente entre a fonte e o ouvinte. Sons com maior reverberação parecem estar em um plano mais profundo. Da maneira que foi utilizada nesta faixa, o efeito resultante se assemelha ao de uma onda que se aproxima, criando um efeito de sentido de movimento o reverb normalmente é utilizado para a composição de uma cena estática. Esse sentido de aproximação é acentuado com o crescimento da intensidade no final da respiração.

A acepção primeira desta introdução é evidente - o som do mar. Com isso a música ganha um aspecto "pictográfico", desenhando uma paisagem através dos seus signos (som, alto, mar, abaixo, onda). A tridimensionalidade fica por conta do plano vertical estabelecido com a oposição do alto e baixo, e com o plano horizontal da onda se quebrando e se aproximando.

Depois da introdução, temos um pequeno arranjo de vozes pronunciando a palavra "amarelanil". A construção deste arranjo é interessante: temos uma voz central que entoa a palavra toda, e duas outras vozes que entoam apenas o fragmento "maré". Estas duas vozes adicionais estão nos limites opostos da tessitura, como que emoldurando a voz principal. A paisagem inicial ganha cores: podemos extrair daqui as palavras "amarelo", "anil", além de "mar" e "maré". 
Ouve-se então a palavra palindrômica "anilina", que foi gravada e tocada ao contrário - fato que é possível deduzir a partir da artificialidade da articulação. A palavra “amaranilanilinalinarama" é apresentada duas vezes, a primeira em sua forma original, e a segunda invertida. Finalmente, ouvimos de novo a palavra "anilina", também invertida.

Uma nova seção inicia com o retorno das palavras som e mar. Ao invés de uma repetição, temos aqui uma dupla oposição. A palavra som está no grave e a palavra mar no agudo - temos uma inversão da posição no campo das alturas. Além disso, as duas palavras são apresentadas juntas (intervalo harmônico) e não na seqüência (intervalo melódico) como na introdução. Ao fazer isso, fica evidente a tensão do intervalo que as separa (sétima maior). Esse intervalo tem algumas propriedades interessantes. Os acordes podem ter duas formações na sua estrutura de base: a tríade (três notas) ou a tétrade (quatro notas). A tríade é formada pela fundamental, a terça e a quinta. A tétrade tem as mesmas notas da tríade e a sétima. A aceitação da tétrade como estrutura de base do acorde em música popular se deu através da difusão do jazz, que no Brasil influenciou diretamente a bossa-nova. Esse fato lançou diversas polêmicas equivocadas sobre o significado dessa estrutura. Para alguns, ela seria capaz de diferenciar a música harmonicamente sofisticada de outras mais simples (leia-se: menos valiosa). Para outros, essa harmonização seria o símbolo da deterioração das origens da nossa música. Nada disso pode ser comprovado musicalmente - seria o mesmo que desprezar a música de Mozart ao estudar a harmonia em Chopin, ou afirmar que este último deturpou as origens da música européia. Polêmicas a parte, o fato é que aceitar a tétrade significa aceitar um acorde que tem relações internas mais tensas (a evolução da história da música se deu exatamente nesse sentido, desde o cantochão). A tensão da tétrade, ou seja, a tensão resultante de incluir mais uma nota na tríade perfeita é a 
tensão inevitável da evolução, ou em outras palavras, da modernidade. ${ }^{1}$ Esse efeito tenso aqui é potencializado pela ausência da mediação da terça e da quinta.

A faixa continua com várias vozes que falam e depois gritam em um crescendo de intensidade a palavra silêncio. Por si só, o "grito de silêncio" já contém uma oposição paradoxal básica: é o extremo da intensidade sonora clamando pela anulação desta mesma intensidade. Dentro deste contexto, este grito parece ser um pedido de negação da modernidade representada pelo intervalo apresentado. O silêncio se faz, mas logo depois ouve-se a palavra não e de novo som, no agudo, deixando clara a idéia de que a faixa poderia recomeçar e se repetir indefinidamente. Temos aqui a negação da negação, ou a parada da parada: a faixa continua, ou seja, a modernidade continua seu curso.

Fica clara mais uma vez a tentativa de decompor a palavra e o som. Criou-se também uma nova figura em música, dando dimensão espacial ao som, à semelhança do que o concretismo tentou fazer em poesia. Segundo os créditos, a música é "inspirada por/dedicada a Augusto de Campos", e conta com "a presença \& help de Arnaldo dos Mutantes”. Segundo o próprio Caetano, foi o poeta concretista Augusto de Campos que chamou sua atenção sobre as possibilidades dentro da palavra amaralina, e que a partir daí criou a palavra palindrômica, que, na gravação da faixa, foi justaposta a uma reprodução dela mesma, tocando ao contrário, e soando idêntica². A palavra "amaranilanilinalinarama" é uma montagem da qual se extrai amarelo, anil, anilina, amaralina, mar e rama. Caetano como que "decompõe" a palavra e exterioriza seus componentes: amarelo (sol), anil (azul,

\footnotetext{
${ }^{1}$ Cf. WISNIK, José Miguel.. O som e o sentido. São Paulo: Companhia das Letras - Círculo do Livro, 1989, p. 116: "A ampliação da faixa daqueles intervalos aceitos como consonância iria seguindo historicamente os passos da série harmônica" e p. 134: "A história do sistema tonal é a história da administração desse jogo relativístico, à medida que se admitem graus cada vez maiores de defasagens de freqüencias ou de tensões harmônicas".

${ }^{2}$ Cf. VELOSO, 1997. p. 490.
} 
céu e mar), anilina (corante, o que dá cor à), mar e amaralina, que designa tanto a praia como o bairro de Salvador em que Caetano morou. É interessante notar que desta mesma palavra se extrai rama (conjunto de ramos). Todas as possibilidades de derivação (ramagens?) já estavam previstas na palavra original.

A oposição trabalhada no nível fundamental é a própria idéia de oposição. A inversão do registro entoado em "som" e "mar", as palavras palindrômicas pronunciadas e invertidas mecanicamente, as vozes altas e estridentes pedindo silêncio, esse silêncio sendo negado pela palavra "não", e a seqüência das palavras pronunciadas ("anilina", “amaranilanilinalinarama", "amaranilanilinalinarama", “anilina”) sugerem a categoria ordem natural vs ordem inversa. Só que aqui não temos nenhuma sobredeterminação explícita da categoria fórica: a oposição aparece apenas como uma possibilidade natural.

São determinados dois planos isotópicos. O primeiro é figurativo, e caracteriza um espaço determinado: a praia de Amaralina. Essa isotopia é construída a partir da isotopia do mar ("mar", “anil", “amarelo"), e concretizada na palavra "amaralina". É importante lembrar que o espaço caracterizado é recorrente na obra, e aparece figurativizado de diversas maneiras. Seja na imagem do recôncavo, do sertão, do samba de roda, do mar, da praia de Amaralina, todas essas figuras remetem à Bahia, terra natal do compositor. A outra isotopia é temática, a isotopia da inversão. O tema central retratado nessa faixa é justamente essa possibilidade de inversão de valores.

O título da faixa é mais uma alusão à gravação da "De conversa em conversa" por João Gilberto. Aqui, adequada à proposta do álbum, o título propõe uma análise mais aguda e intensa, estabelecendo a oposição entre palavra e conversa. A modernidade representada 
pelo maior protagonista da bossa-nova já havia sido incorporada ao material sonoro com a apresentação do intervalo de sétima maior.

A análise da proto-melodia criada pela faixa também fornece elementos interessantes para a composição do sentido final. Há uma oposição clara entre grandes saltos intervalares, de um lado, e a sustentação de uma mesma nota e graus conjuntos, de outro. Como vimos, as palavras iniciais som e mar estão separadas por intervalo de sétima. A frase seguinte, amarelanil, parte do centro da tessitura, descendo por graus conjuntos até retornar ao centro por um salto de quatro tons. Mais interessante é o "eco" das sílabas ma e re sete tons e meio abaixo e uma oitava acima, tocando os extremos da tessitura. Dessa maneira, um elemento intenso (a melodia) provoca um eco nos limites da tessitura (elemento extenso), revelando assim a sua imensa amplitude.

A seqüência anilina é uma pequena parábola com a concavidade para baixo, onde as notas são separadas por intervalo de semitom. Apesar do semitom ser o menor intervalo possível entre as notas na cultura ocidental, essa seqüência ainda contrasta com a palavra amaranilanilinalinarama, que permanece numa nota só. Mais uma vez, opõe-se um elemento intenso (a sustentação de uma nota) com um extenso (a distribuição de notas perfazendo um motivo). E, com essas duas operações, fica evidente todo o processo de articulação musical, do extenso ao intenso: a delimitação de uma tessitura, de uma escala, de um motivo diatônico, de um motivo cromático, de uma nota. 


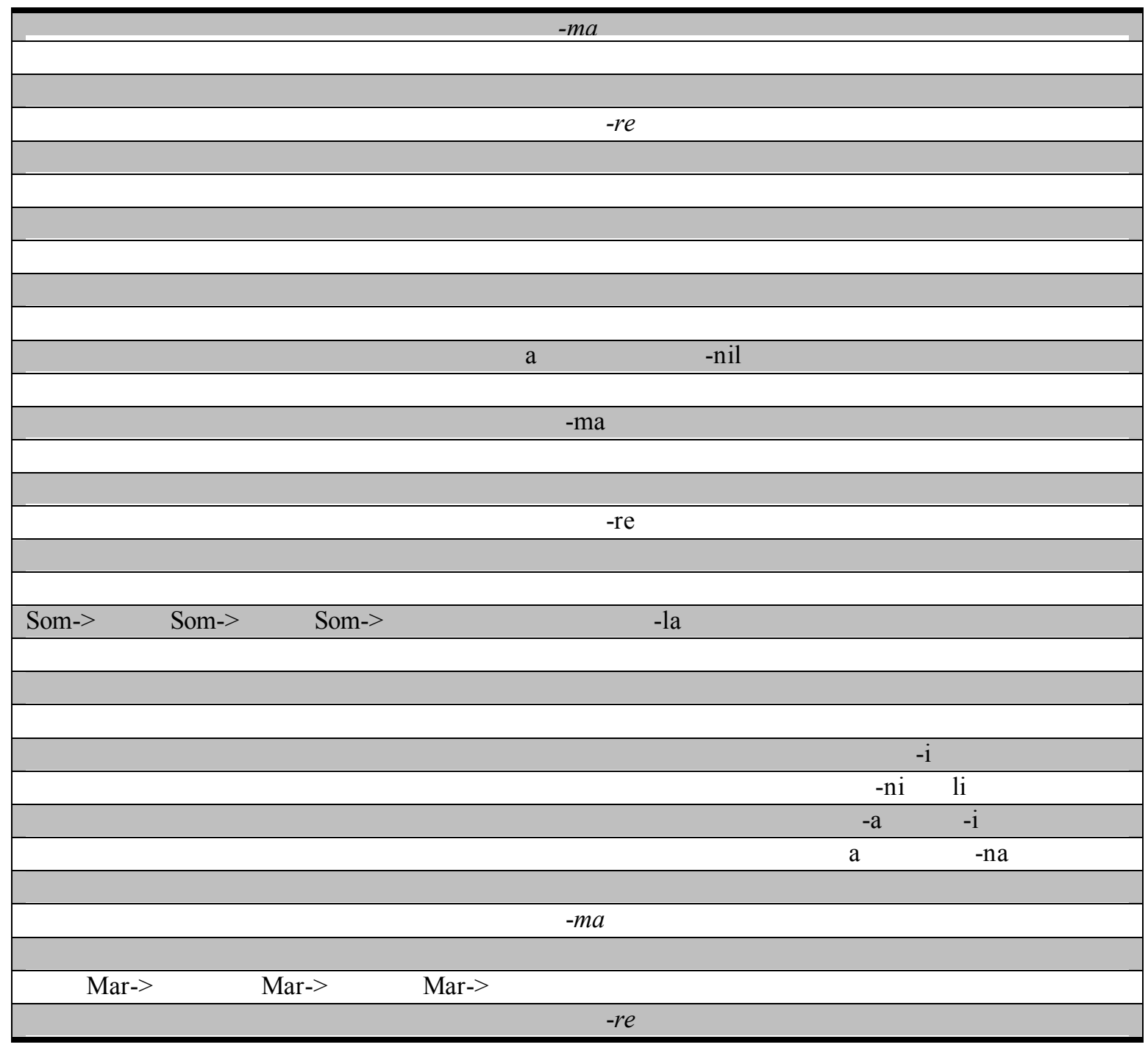




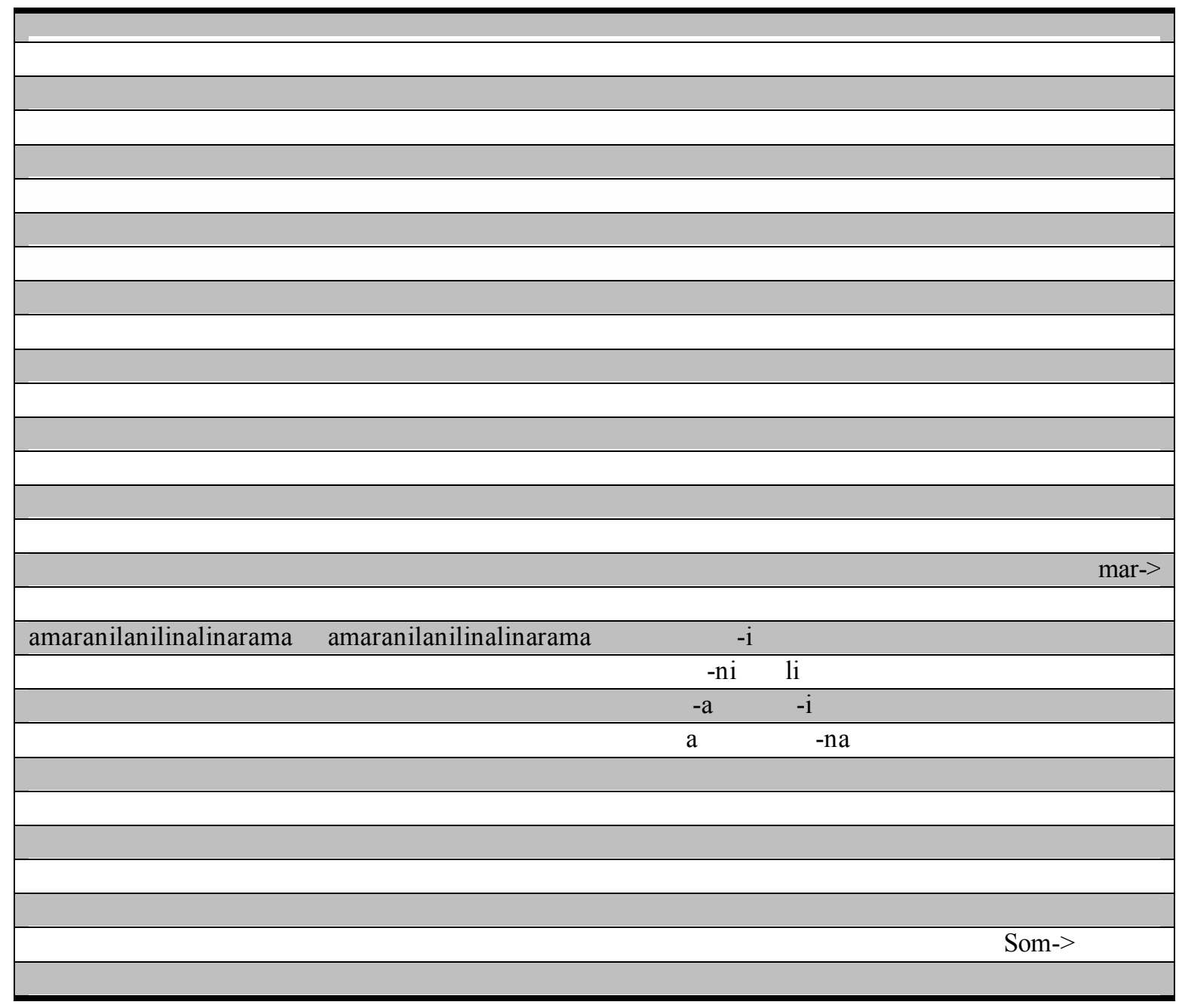




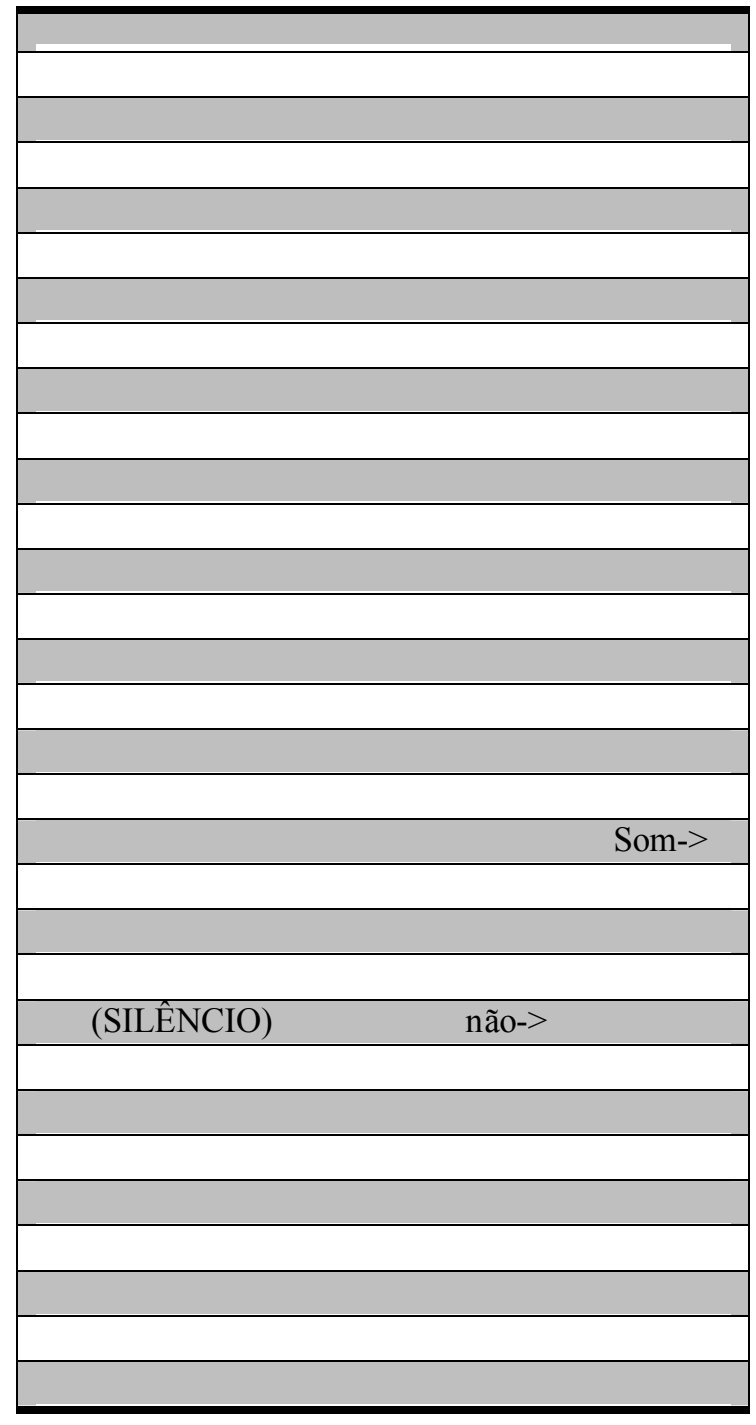




\subsection{De Cara / Quero essa mulher assim mesmo}

A sexta faixa recebe o título "De Cara", seguido pelos nomes de Lanny e Caetano Veloso. Os nomes não estão entre parênteses, como nas demais canções - tudo indica que eles não são os compositores desta faixa. Logo após vem o título verdadeiro, "Quero essa mulher assim mesmo", e a indicação "do genial Monsueto Menezes" - este sim, o compositor da canção. Ao ouvir a faixa, nota-se que essa música é executada sem cortes em toda a faixa. No entanto, Caetano preferiu intitular a faixa de "De cara" ao invés de colocar apenas o nome da música como em “Tu me acostumbraste". Com isso, ele sugere a idéia de que "de cara" é uma expressão, e não um título, e pode indicar que a música foi gravada sem (ou com pouco) ensaio prévio.

\footnotetext{
Eu quero essa mulher assim mesmo

Eu quero essa mulher assim mesmo

Essa mulher assim mesmo, eu quero

Eu quero essa mulher assim mesmo
}

Eu quero essa mulher assim mesmo, baratinada

Quero essa mulher assim mesmo, alucinada

Quero essa mulher assim mesmo, despenteada

Quero essa mulher assim mesmo, descabelada

Quero essa mulher assim mesmo, embriagada

Quero essa mulher assim mesmo, intoxicada 
Quero essa mulher assim mesmo, desafinada

Quero essa mulher assim mesmo, desentoada

Quero essa mulher assim mesmo

Depois do último verso, há um grande trecho instrumental, em que todos os instrumentos se apresentam virtuosisticamente, prática própria do rock progressivo da década de 70. O arranjo dado a esta faixa mais uma vez deixa clara uma das faces da proposta tropicalista, a de reconhecimento de todas as tendências musicais, internas ou externas, como formadoras da música e musicalidade do Brasil. Apesar de ter sido composta como samba, essa faixa soa extremamente bem como um rock'n'roll (“é a mesma dança meu boi”).

Essa canção joga com o duplo sentido da expressão "assim mesmo". Essa expressão pode assumir o sentido de resignação (que ficaria explícito se a expressão fosse "mesmo assim"). Nesse caso a expressão se aproximaria do sentido de "apesar disso". O outro sentido possível é o da intencionalidade, caso em que a expressão se aproximaria de “exatamente assim”. No primeiro caso, teríamos a paixão da resignação, situação em que o sujeito aceita estar em conjunção com valores disfóricos. No segundo, teríamos o efeito de sentido da justa medida, da perfeita adequação.

A primeira interpretação colocaria os valores apresentados ("baratinada", "alucinada", “despenteada", “descabelada", “embriagada", "intoxicada", "desafinada", “desentoada”) como disfóricos. Já a segunda, como eufóricos. Mais uma vez trabalha-se com a possibilidade de inversão de valores. 
As funções actanciais são de sujeito e objeto, sendo que a segunda interpretação sugere também que o "eu" estaria desempenhando a função de destinador, doando os valores para o destinatário "mulher".

A figura criada é a da rebeldia e a da liberdade, através dos termos "baratinada", "alucinada", “despenteada", “descabelada", “embriagada", "intoxicada", "desafinada", “desentoada". Há uma recorrência de termos que sugerem o rompimento com regras legais (a proibição do uso de drogas, em "intoxicada", "alucinada", "baratinada", "embriagada"), regras de apresentação pessoal (“despenteada", "descabelada"), e até mesmo musical (“desafinada" e “desentoada"). Esse procedimento é responsável pela criação de um ethos, imediatamente associado à juventude da década de 60. O uso do gênero rock'n'roll no arranjo musical confirma essa associação.

A debreagem utilizada é a enunciativa, que subjetiviza o discurso, criando o efeito de sentido de aproximação. Essa faixa realiza explicitamente um dos principais pontos do movimento modernista, a antropofagia. A releitura em rock de uma canção já consagrada no gênero samba gera um impacto ainda maior do que a prática tropicalista de compor gêneros brasileiros com instrumentos elétricos. Fica claro que a proposta não se limita a uma modernização do fazer musical no Brasil, mas também possibilita uma ampla releitura do passado. Dessa forma, a faixa sugere a aceitação dos valores externos. Essa aceitação se dá tanto na música, pela escolha do estilo, como na letra. Seja com resignação, seja com plena aceitação, o sujeito aceita os valores creditados a "essa mulher". A rigor, o emprego do termo "essa", e não "esta", poderia sugerir que os valores aceitos estão fora do campo de atuação do sujeito, o que enfatiza o sema "externo" dessa aceitação. No entanto, o uso da fricativa "s" em "essa", que promove a continuidade da emissão sonora, em oposição à 
linguodental "t" em "esta", que impõe o corte da passagem de ar, sugere mais a idéia de contigüidade, aproximando o objeto do sujeito.

O andamento da canção é rápido e a marcação rítmica é forte. Toda a canção está marcada por um projeto entoativo que adota o regime da aceleração. Podemos notar a forte presença da tematização no processo de composição. A canção inicia com frases melódicas descendentes, figurativizando uma categórica afirmação.

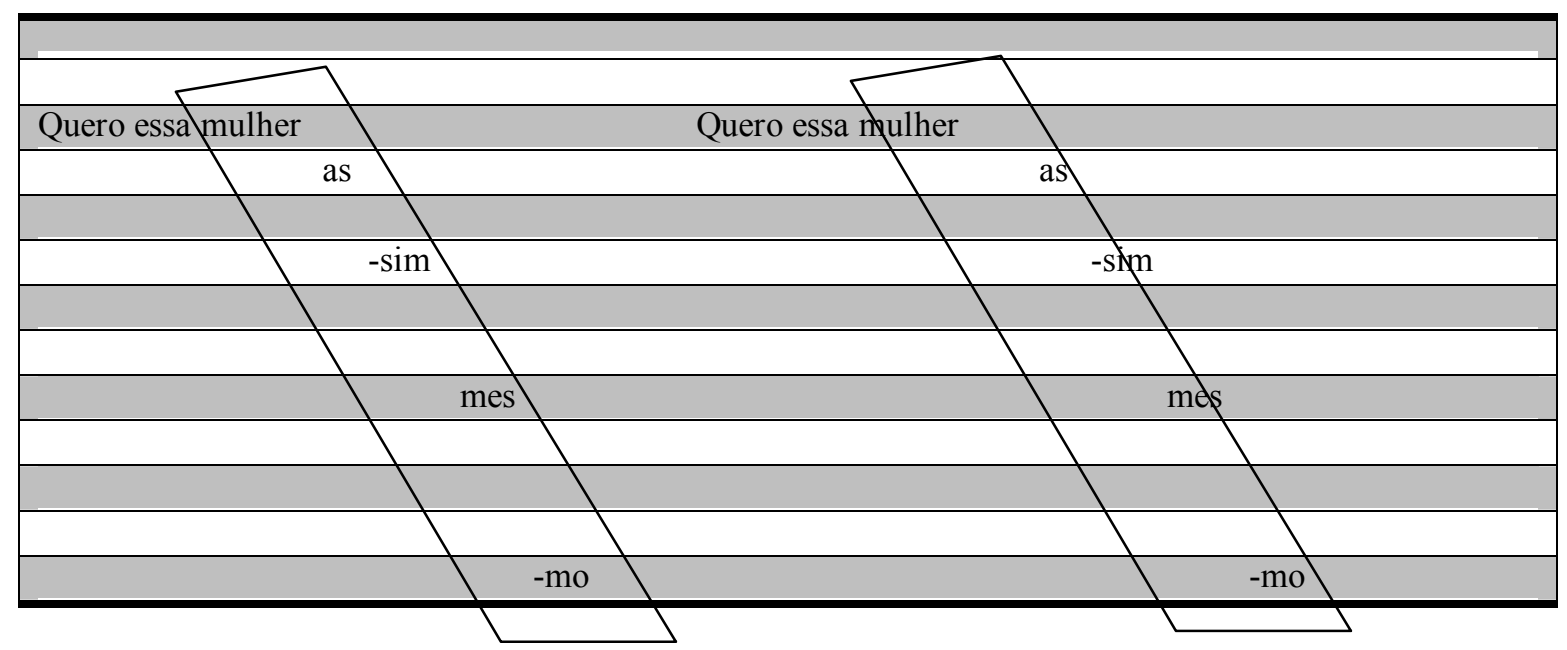


Essa frase é interrompida com um salto ascendente, atingindo o pico da tessitura. Ao mesmo tempo em que se rompe com a afirmação inicial, obtém-se um efeito ainda maior de distensão, pois esta subida aumenta também a tessitura da descida:

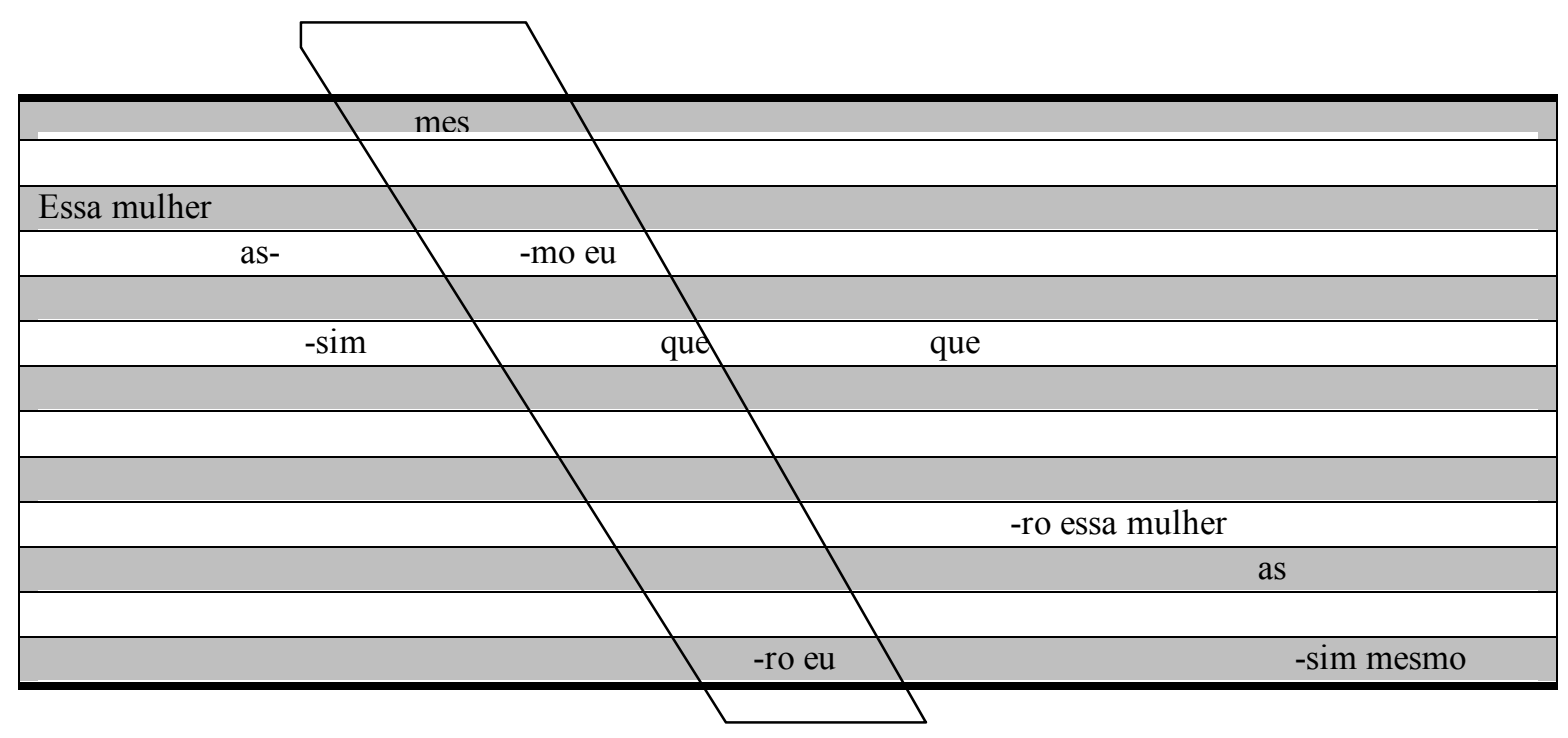

A estrofe encerra com mais uma descida, desta vez até o ponto mais baixo da tessitura, encontrando a fundamental do acorde de tônica - a distensão é total. 
A partir deste ponto, a melodia apenas alterna dois temas, para enumerar as qualidades do objeto:
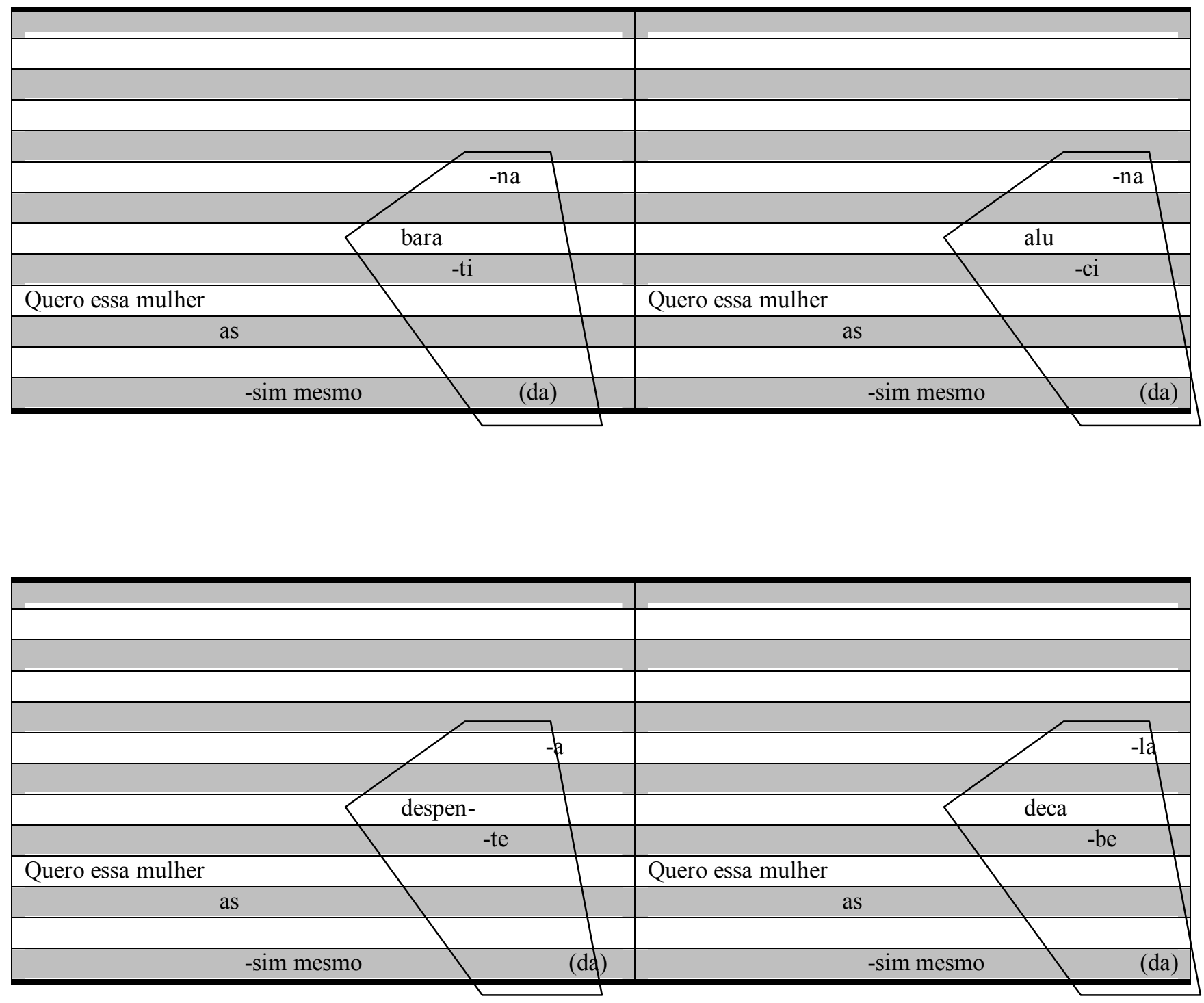

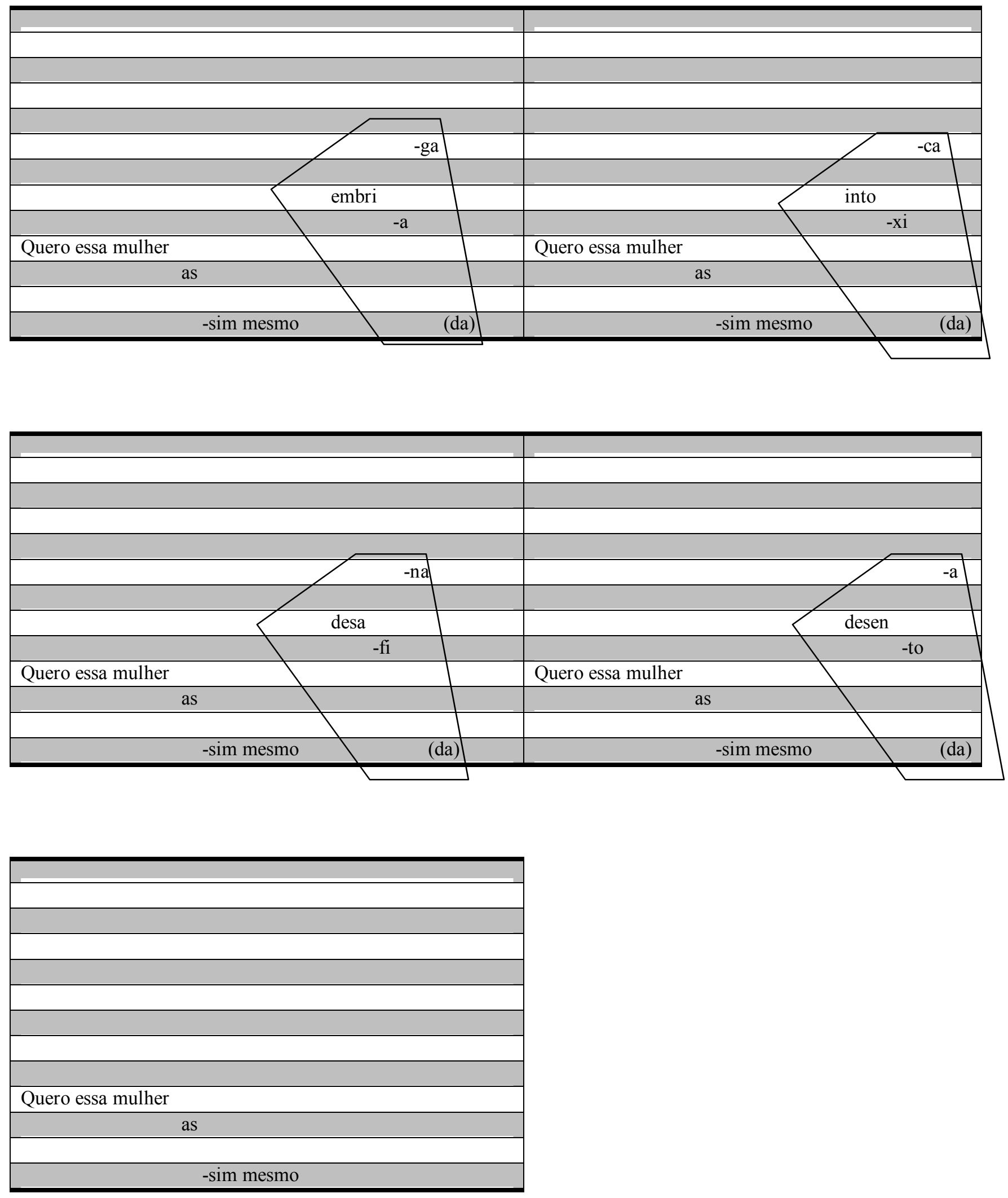
O primeiro tema desta segunda seção é uma repetição daquela afirmação inicial, só que com tessitura reduzida. $\mathrm{O}$ segundo também é, em parte, um reflexo da quebra para o agudo que já havia acontecido na primeira parte. É interessante a justaposição destes dois temas. Enquanto o primeiro reflete uma afirmação categórica, ou seja, a aceitação plena dos valores, o segundo desafia a estabilidade proposta pelo primeiro.

Essa construção melódica retoma, no plano musical, a ambigüidade presente na letra da canção. Enquanto o primeiro tema representa a aceitação plena (a justa medida), o segundo questiona essa posição de aceitação plena (a aceitação mediante resignação). $\mathrm{Na}$ realidade, mais do que simplesmente questionar os valores, a sobreposição da letra e da melodia desta canção sugere que o sujeito sabe que essa aceitação é algo tenso. Ao invés de "resolver" a tensão criada pelo duplo sentido ("assim mesmo" ou "mesmo assim"), o compositor explicita esta tensão na melodia. De fato, todo o arranjo colabora para a manutenção deste clima tenso, desde a escolha do gênero, até as características do solo e principalmente a interpretação vocal. Este é o reflexo no plano musical de todos os contratos sociais rompidos pela aceitação daqueles valores. Extremamente bem construída, a oposição entre a distensão do primeiro tema e a tensão do segundo faz com que a tensão passional embutida na letra seja absolutamente convincente. Com o uso desta estratégia perfeita, a canção é plenamente eficaz.

A inclusão desta canção no álbum mostra a sutil genialidade do processo de construção do sentido nesta obra. Todos os valores creditados ao objeto instaurado pela letra apontam para a idéia de rompimento, de transgressão. Com resignação ou não, esses valores são plenamente aceitos pelo sujeito. Esse objeto transgressor é apresentado em uma canção que realiza uma operação de síntese entre os gêneros que simbolizavam toda a 
rivalidade da época tropicalista: o samba e o rock. Essa canção assume e impõe toda a transgressividade dessa síntese. 


\subsection{Sugar Cane Fields Forever}

O lado B começa com a faixa "Sugar Cane Fields Forever", evidente citação da música dos Beatles "Strawberry Fields Forever”. Assinada por Lennon e McCarthney, esta canção foi lançada pela primeira vez em 13 de fevereiro de 1967 em um compacto, junto

com "Penny Lane". Posteriormente, ela foi incluída no álbum Magical Mystery Tour, lançado em novembro de 1967. Mais do que apenas retomar o diálogo com o rock instaurado na faixa anterior, a citação desta canção dos Beatles representa um ponto crucial na construção do sentido em Araçá Azul.

Sendo um dos primeiros grandes fenômenos mundiais de vendas do mercado fonográfico, é evidente que tanto as canções como também a postura de seus integrantes influenciaram a música e o comportamento no mundo inteiro. No Brasil, os Beatles influenciaram diretamente, em curto espaço de tempo mas de forma bem diferente, dois movimentos distintos: a jovem guarda e o tropicalismo.

As referências aos Beatles na jovem guarda são claras e diretas: dezenas de canções foram traduzidas para o português e gravadas pelos seus intérpretes. O próprio "rótulo" atribuído ao gênero musical por eles defendido é uma menção aos Beatles: a expressão "iêiê-iê" está estampada no refrão da canção "She loves you"1:

She loves you yeah, yeah, yeah

She loves you yeah, yeah, yeah

She loves you yeah, yeah, yeah, yeah 
Da estrutura da composição à instrumentação, dos arranjos ao vestuário e cortes de cabelo, tudo na jovem guarda era uma referência direta aos Beatles, ou aos valores que eles representavam. Curiosamente, a despeito de todas as manifestações de desapreço por parte dos defensores da "tradição musical brasileira", a jovem guarda repetiu, no universo local, o sucesso de público que os Beatles alcançaram mundialmente (sucesso que rendeu o título - até hoje não contestado - de "Rei” ao seu principal protagonista).

Os pontos de conexão entre Beatles e tropicalismo são muito mais numerosos e complexos. Há no tropicalismo uma intenção clara de superar o confronto local estabelecido entre a jovem guarda e os seus rivais conservadores, o que por si só já resultaria na assimilação de seus valores - e portanto indiretamente dos valores inscritos nas canções dos Beatles. Essa relação já seria suficiente para explicar, por exemplo, a escolha dos Beat Boys para a apresentação da canção "Alegria, alegria" no festival da Record. No entanto, outros fatores apontam para um diálogo muito mais próximo do que este. A escolha do grupo Mutantes para levar adiante a proposta tropicalista, por exemplo, é um desses fatores. A leitura dos Beatles feita pelos Mutantes difere bastante do estilo dos Beat Boys. Enquanto os Beat Boys (assim como a jovem guarda) aproximavam-se dos Beatles por imitação, a leitura dos Mutantes era acima de tudo antropofágica:

Se os Beat Boys já tinham se profissionalizado na noite tocando competentemente covers dos Beatles, dos Rolling Stones ou do The Doors, os Mutantes ainda semi-amadores, pareciam não copiadores dos Beatles (muito menos de alguns desses outros grupos de menor popularidade ou importância), mas seus pares, criativos na mesma linha. ${ }^{2}$

\footnotetext{
${ }^{1}$ Esta canção de Lennon \& McCarthney foi apresentada pela primeira vez em um single homônimo, em 23 de agosto de 1963 (Parlophone R 5055 - UK)

${ }^{2}$ Veloso, 1997. p. 171.
} 
A fricção entre o tema afro-baiano e o som deles [dos Mutantes] era instigante Beatles + berimbau ou Beatles x berimbau. ${ }^{3}$

Menos evidente é a relação entre os Beatles e a estrutura da canção "Alegria, alegria”. Enquanto a composição bossa-novista primava pelo suave encadeamento de acordes enriquecidos por tensões (as então chamadas dissonâncias) que lhe emprestavam delicada sofisticação, a típica composição no estilo rock usa acordes mais simples na sua estrutura interna, ligados por uma estrutura maior que é o campo harmônico ${ }^{4}$ da tonalidade da composição. A originalidade desta composição tropicalista é utilizar (já na introdução) acordes oriundos de campos harmônicos diferentes, o que gera um interessante efeito de surpresa e de quebra de expectativa. Este procedimento ("misturar" acordes de campos harmônicos diferentes) foi muito usado pelos Beatles, e acabou tornando uma característica comum da composição pop.

Em flagrante e intencional contraste com o procedimento da bossa-nova, que consistia em criar peças redondas em que as vozes internas dos acordes alterados se movessem com natural fluência, aqui opta-se pela justaposição de acordes perfeitos maiores em relação insólita. Isso tem muito a ver com o modo como ouvíamos os Beatles [... $]^{5}$

Progressivamente, a banda de Liverpool distanciou-se das composições mais "extrovertidas" da primeira fase. Suas composições aprofundaram-se tanto musicalmente quanto tematicamente, enquanto os arranjos ficaram cada vez mais ricos e complexos. A banda que criara e consolidara um estilo extremamente característico se vê permeada de influências das mais diversas, da música indiana de Ravi Shankar à eletroacústica de

\footnotetext{
${ }^{3}$ Ibid. p. 180, sobre a apresentação de "Domingo no parque"

${ }^{4}$ Campo harmônico é o conjunto de acordes formados por notas de uma mesma escala.
} 
Stockhausen, dos arranjos barrocos ao atonalismo. Ao mesmo tempo em que a banda amadurece musicalmente, cresce também a experiência em técnicas de gravação e mixagem em estúdio. Ao analisar a trajetória das composições dos Beatles, pode-se perceber claramente duas buscas distintas e simultâneas. Se por um lado há um investimento na procura da canção "redonda", lírica, de melodia límpida e cristalina ("Here, there and Everywhere", "The long and Widding Road", "In my life”), há também uma intensificação progressiva do experimentalismo, que se manifesta não só com o uso de manipulação sonora em estúdio, mas também na estrutura das composições, nos arranjos, nas letras e na interação destas com as melodias ("I am the Warlus", "Number nine", "Within you, without you"). De certa forma, a trajetória dos Beatles reflete um período da história da música brasileira, que também passou (não obrigatoriamente na mesma ordem) por uma busca lírica (na bossa-nova), pela alienação ao mesmo tempo ingênua e criativa do iê-iê-iê da jovem guarda, e pela experimentação intensiva do tropicalismo. O processo que permitiu esta transformação na produção musical da banda inglesa é muito similar à antropofagia de Oswald, vividamente ressuscitada no tropicalismo. Munidos de uma visão menos parcial e dicotomizada que seus pares, os tropicalistas conseguiram enxergar nitidamente a complexidade, a originalidade, a força e a significância desta obra. Mais interessante ainda é o fato de que a absorção da informação oriunda dos Beatles entrou no fazer tropicalista exatamente desta maneira: antropofagicamente. Nesta citação, Caetano "regionalizou" o título da música da banda londrina ao substituir "Strawberry" por "Sugar Cane". Não há, até o Araçá Azul, nenhuma citação direta aos Beatles, mas apenas referências aos

\footnotetext{
${ }^{5}$ Ibid. p. 169.
} 
procedimentos por eles empregados. Por isso mesmo, há aqui também um certo “didatismo" na escolha do título desta faixa.

A idéia do canibalismo cultural servia-nos, aos tropicalistas, como uma luva. Estávamos "comendo" os Beatles e Jimi Hendrix ${ }^{6}$

[...] o experimentalismo ostensivo de Sargent Pepper's Lonely Hearts Club Band estava mais próximo não só do que fazíamos como dos grandes artistas que eu admirava, fossem eles Godard, Oswald, Augusto de Campos, João Cabral, Joyce, Lewis Carrol ou e. e. Cummings ${ }^{7}$

A escolha da "Strawberry Fields Forever" para estabelecer o laço com os Beatles é extremamente rica em significados. Em todos os sentidos, esta é uma canção absolutamente singular. Letra, melodia, arranjo, forma e história concorrem para fazer dela um verdadeiro ícone dentro da obra dos Beatles.

Let me take you down 'cause I'm going to Strawberry Fields

Nothing is real and nothing to get hung about

Strawberry Fields Forever

Living is easy with eyes closed

Misunderstanding all you see

It's getting hard to be someone but it all works out

It doesn't matter much to me

${ }^{6}$ Ibid. p. 247.

${ }^{7}$ Ibid. pp. 271-272. 
Let me take you down 'cause I'm going to Strawberry Fields

Nothing is real and nothing to get hung about

Strawberry Fields Forever

No-one I think is in my tree

I mean it must be high or low

That is you can't you know tune in but it's all right

That is I think it's not too bad

Let me take you down 'cause I'm going to Strawberry Fields

Nothing is real and nothing to get hung about

Strawberry Fields Forever

Always no sometimes think it's me

But you know I know and it's a dream

I think I know of thee ah, yes but it's all wrong

That is I think I disagree

Let me take you down 'cause I'm going to Strawberry Fields

Nothing is real and nothing to get hung about

Strawberry Fields Forever

Strawberry Fields Forever

Strawberry Fields Forever 
Deixe-me te deprimir pois eu estou indo para Strawberry Fields

Nada é real e nada para se preocupar

Strawberry Fields para sempre

É fácil viver com os olhos fechados

Compreendendo mal tudo o que vê

Está ficando difícil ser alguém mas tudo dá certo

Isso não importa muito para mim

Deixe-me te deprimir pois eu estou indo para Strawberry Fields

Nada é real e nada para se preocupar

Strawberry Fields para sempre

Ninguém eu acho que está em minha árvore

Quero dizer, é preciso ser alto ou baixo

Isto é você não consegue, você sabe, afinar, mas está tudo certo

Isso eu acho que não é tão mal

Deixe-me te deprimir pois eu estou indo para Strawberry Fields

Nada é real e nada para se preocupar

Strawberry Fields para sempre

Sempre não às vezes pense que sou eu

Mas você sabe que eu sei e isto é um sonho

Eu penso que sei, ah, sim, mas está tudo errado

Isso eu acho que discordo 


\section{Deixe-me te deprimir pois eu estou indo para Strawberry Fields}

Nada é real e nada para se preocupar

Strawberry Fields para sempre

Strawberry Fields para sempre

Strawberry Fields para sempre

O conceito de "arranjo" é muito mais amplo do que possa parecer para o ouvinte comum. Ele normalmente é confundido com "arranjo de base", que é a instrumentação que tipicamente acompanha uma melodia, cantada ou não, e é responsável pelo aspecto rítmico e harmônico. O arranjo propriamente dito engloba todos os aspectos de uma produção musical, incluindo o arranjo de base, mas também a ordem em que as estrofes serão apresentadas, a existência de introduções e pontes conectando as partes, o número de repetições de cada parte, os contrapontos, as melodias incidentais e os arranjos vocais, a dinâmica ${ }^{8}$. A interpretação escolhida para instrumentos e vozes também é um aspecto do arranjo. Uma música não tem arranjo: ela é um arranjo. Visto desta maneira, em uma música gravada, o arranjo é um processo que tem como ponto de partida a composição e termina na edição e na mixagem. A ênfase dada a esta etapa do arranjo, a de edição em estúdio, é um importante elo de ligação entre a "Strawberry Fields" e todo o LP Araçá Azul.

Apesar de apresentar elementos suficientes para caracterizá-la como sendo uma composição "experimental", "Strawberry Fields" preserva nitidamente uma estrutura de canção. Temos uma introdução instrumental, a apresentação do refrão, três conjuntos de

\footnotetext{
${ }^{8}$ A dinâmica é responsável pela escolha e variação de intensidade e andamento
} 
estrofe e refrão, e um final instrumental. A única exceção a essa estrutura formal é o aparecimento de um "apêndice", poucos segundos após o aparente término da execução da canção. Na realidade, esse apêndice é criado com um fade out antecipado, antes do final real da faixa, já no trecho instrumental. O resultado é um pequeno trecho em silêncio, seguido por uma curta retomada. Com esse procedimento, os Beatles criam uma interessante ressonância entre o moderno, representado pelos elementos "experimentais", e o tradicional: a forma canção.

$\mathrm{O}$ aspecto mais evidente do experimentalismo de "Strawberry Fields" é a sobreposição dos instrumentos típicos de uma banda de rock (guitarra, baixo, bateria e teclado), instrumentos de orquestra (violoncelos e trompetes) e uma harpa indiana (swordmandel). Este procedimento promove uma síntese ao mesmo tempo entre o tradicional e o moderno, e entre a cultura ocidental e oriental. Esta sobreposição é um dos componentes centrais da prática musical tropicalista, amplamente utilizada por Caetano neste álbum.

O trabalho de edição e mixagem da "Strawberry Fields" tornou-se uma lenda na história dos Beatles. Alguns trechos da música foram gravados em tons diferentes e andamentos diferentes, para depois serem adaptados manualmente, com a reprodução da fita em outra velocidade. Alguns ruídos também foram inseridos através da manipulação em estúdio: temos por exemplo o som de pratos de bateria tocados "ao contrário" na segunda estrofe da canção. Este mesmo procedimento foi usado na faixa "De palavra em palavra". O "apêndice" também é formado por sons de flauta, tocados no teclado (melotron), e reproduzidos "ao contrário". Os instrumentos de orquestra foram todos gravados separadamente, e depois mixados com o restante da banda. Apesar de toda esta 
colagem, a faixa ainda tem o claro propósito de parecer ser um todo coeso. A transição entre as partes nunca é abrupta, e o "apêndice" é inserido com fade, o que suaviza a sua aparição.

A análise da letra da "Strawberry Fields" completa o leque de ligações com o Araçá Azul. "Strawberry Fields" é uma música feita a partir de reminiscências da infância de John Lennon, assim como Penny Lane para Paul McCarthney. A capa do compacto em que elas foram lançadas era composta por fotos dos dois compositores quando bebês. A busca de elementos de origem, tão explorada no Araçá Azul, é evidente nestas canções.

Strawberry Field é o nome de um orfanato para crianças do Salvation Army, que Lennon freqüentava quando criança. Nos versos iniciais da primeira estrofe ("É fácil viver com os olhos fechados", "Compreendendo mal tudo o que vê") há uma manifestação de lucidez que aparentemente destoa do resto do texto. A letra desta canção mostra um sujeito nitidamente fragmentado e desorientado ("Está ficando difícil ser alguém", "Ninguém eu acho que está em minha árvore", "Sempre não às vezes pense que sou eu”). No entanto, o sujeito constrói sua identidade justamente a partir desta condição. Isso pode ser visto principalmente nas afirmações finais de cada estrofe, em que o ele, a despeito de sua desorientação, manifesta sua opinião sobre o que acabou de afirmar ("Isso não importa muito para mim", “Isso eu acho que não é tão mal", "Isso eu acho que discordo"). Nesta canção, há um movimento pendular constante entre devaneio e lucidez, simbolizado por um sujeito que ora se fragmenta, ora se recompõe.

Os Beatles teceram um arco gradual que vai do Please, please me ao Abbey Road, do iê-iê-iê de estrutura formal ao experimentalismo mais radical. A dimensão do choque vivenciado pela platéia brasileira na explosão tropicalista se deve em parte pela ausência da 
gradação entre estes dois opostos no fazer musical da época. O experimentalismo da síntese tropicalista entre o iê-iê-iê e o folclore nacional, com todos os seus conteúdos musicais e não musicais, aconteceu sem historicidade e sem aviso prévio para a maioria do público consumidor de música da época, a despeito dos mais de 40 anos de antropofagia. Esse fato ajuda a sustentar o uso freqüente da palavra "explosão" para se referir ao movimento. Ao mesmo tempo em que o Araçá Azul retoma o experimentalismo tropicalista, ele de certa forma recompõe o elo estabelecido com essas fontes não explicitamente apresentadas no Panis et Circenses.

A estrutura da faixa "Sugar cane fields forever", a mais longa do álbum, difere muito da canção dos Beatles. Em "Strawberry Fields", toda a manipulação é feita para criar a sensação de continuidade entre as partes, e o resultado final é uma canção coesa. Já na Sugar Cane, temos uma sucessão de trechos recortados quase sempre sem transições suaves, com mudança súbita de tom e andamento. Alguns desses trechos são pedaços de sambas de roda e pequenas canções autônomas, que são apresentados e depois dissolvidos por intervenções orquestrais atonais, recobertas por vozes. A intervenção "experimentalista", neste caso, atingiu estruturas mais profundas do arranjo, explicitando seu caráter.

A introdução da faixa é feita por um pequeno solo livre, ad lib, em flauta de bambu. Essa é uma interessante referência à canção dos Beatles, que inicia com um solo de flauta sintetizada no melotron. É ao mesmo tempo um flagrante antropofágico e uma retomada no plano musical da citação feita pelo título. Esse solo é coberto pela entoação dos versos: 
Verdes mães

Verdes mães

Mães

Após a introdução, é apresentado um samba de roda entoado por D. Edith, acompanhada pelo prato, por um atabaque e pelo coro que canta e palmeia.

Pacuri estava sentado

Lá na beira da lagoa

Esperando a pata nova

Pra que lado ela voa

Xô pacuri, (na lagoa)

Xô pacuri, (na lagoa)

A melodia do refrão é dobrada pelos violinos, até ser parcialmente encoberta por eles. O samba de roda passa para o segundo plano, e a orquestra realiza um pequeno trecho atonal, concomitantemente com a entoação dos versos "cavalinho de flecha, cavalinho de flecha, cavalinho". O samba de roda volta ao primeiro plano, com o desaparecimento da orquestra.

Mais uma vez, podemos perceber uma regionalização do processo criativo observado em "Strawberry Fields". Ao unir a orquestra ao samba de roda e o atonalismo à forma ritualística da festa de terreiro, Caetano apresenta uma versão musical do sincretismo afro-católico baiano, misturando as fontes musicais e religiosas afro-européias. 
Um novo trecho inicia com o desaparecimento do samba de roda, e o retorno da orquestra atonal, acompanhada por Caetano entoando num ostinato a frase "eu quero", com melodia descendente. "Querer" é um verbo transitivo direto e indireto. A repetição deste verbo sem objeto cria um interessante efeito, ainda mais acentuado pelo acompanhamento instrumental. Da mesma maneira em que o atonalismo quebra a sintaxe estabelecida pelo tonalismo, este verbo sem objeto também quebra uma sintaxe lingüística. Este movimento coordenado entre o plano musical e lingüístico deixa a entender que o que rege este trecho não é a desorganização (como na "Strawberry Fields") mas sim a proposição de uma nova organização, em outro nível. A relação metonímica entre estes dois planos desacelera as passagens bruscas que ocorrem na seqüência sintática dos trechos apresentados. A força desta competência modal do sujeito, em conjunção com o querer, é potencializada não só pela repetição insistente mas também pela forma descendente da melodia que sustenta a frase. Essa força também é mais um elemento reestruturante, que empresta coesão à expressão sintaticamente desestruturada.

Um novo samba de roda surge progressivamente até tomar o lugar da orquestra e da voz, que desaparecem.

Meu Deus onde eu vou coarar

(Coarar minha roupa)

Meu Deus onde eu vou coarar

(Coarar minha roupa)

O guarda civil não quer 
A roupa no coarador

O guarda civil não quer

A roupa no coarador

Meu Deus onde eu vou coarar

(Coarar minha roupa)

Meu Deus onde eu vou coarar

(Coarar minha roupa)

\begin{abstract}
Nesta primeira parte da faixa, esboça-se uma estrutura por sobre a polifonia aparentemente desorganizada:
\end{abstract}

Trecho vocal acompanhado por flauta (verdes mães)

Samba de roda (xô Pacuri)

Transição: orquestra dobrando samba de roda

Trecho vocal acompanhado por orquestra (cavalinho de flecha)

Samba de roda (xô Pacuri)

Trecho vocal acompanhado por orquestra (eu quero)

Samba de roda (onde eu vou coarar) 
Esta estrutura de repetições é mais um mecanismo de reaproximar os elementos aparentemente desconectados. Por baixo da evidente fragmentação, há também uma proposta de reestruturação. A tensão entre ordem e desordem presente no arranjo desta primeira parte encontra uma fina ressonância na letra do segundo samba de roda. Também ali temos a estruturação de uma nova ordem representada pela figura do guarda civil, e a conseqüente tensão que sua atuação gera na situação descrita.

Entra sozinho um violão acompanhando a melodia no registro grave "Oi, quem não tem balangandãs", cantada à maneira de Dorival Caymmi. O violão executa uma batida sincopada, típica do samba, mas mantém sua célula rítmica inalterada em toda a passagem. A harmonia alterna os acordes E7(9) e A6, formando a estrutura básica da harmonia, a cadência dominante-tônica. A dominante é a função que transmite a sensação de "preparação", "tensão", "movimento". A tônica é a função de "resolução", "distensão", "repouso". Essa cadência é o "motor" da música ocidental, desde o surgimento da harmonia, na renascença. É o movimento mais forte em música. Aqui, a tensão da dominante é rapidamente "resolvida" pelo acorde de tônica: a estabilidade é perfeita. Em um ambiente tão desorganizado, a forte estruturação desta passagem gera um efeito surpreendente: é um imenso alívio para toda a tensão até então acumulada. Este é o primeiro trecho da faixa que apresenta uma melodia acompanhada nos moldes "tradicionais". Em outras palavras, é a primeira canção imediatamente reconhecível como tal.

É interessante ter sido este o momento escolhido para apresentar alguns elementos e valores inscritos no texto e na melodia. Há uma citação dupla a Dorival Caymmi, tanto pela letra quanto pela interpretação vocal. Os balangandãs são apresentados em "O que é que a 
baiana tem?" como sendo a síntese de todas as competências necessárias para a legitimação da baiana, cuja veridicção seria premiada com a entrada no Bonfim. Essa é uma ponte para a conexão com Carmem Miranda, anteriormente citada na canção "Tropicália", um dos grandes símbolos utilizados pelo tropicalismo.

Sobrepõe-se uma nova melodia, entoando a frase:

Sou um mulato nato no sentido lato mulato democrático do litoral

A construção desta frase é extremamente rica em significados. $\mathrm{O}$ mulato é resultado da mistura das raças negra e branca. Ele é a personificação da síntese entre Europa e África, mistura que estava na origem do povo brasileiro. A democracia atribuída ao mulato é, acima de tudo, uma democracia étnica. "Lato" é "largo, amplo, dilatado, extenso". "Nato" refere-se às qualidades de nascença, qualidades congênitas. Empregado para qualificar uma etnia, que é sempre necessariamente congênita, ele ganha um sentido mais amplo. A justaposição dos adjetivos "nato" e "lato", como se estes saíssem da palavra "mulato", emprestam a este autenticidade e originalidade suficientes para distanciá-lo da origem e instaurá-lo como algo novo, original e autônomo.

A maneira como este verso foi musicado é também interessante. Na primeira metade os acentos métricos da frase estão em fase com os acentos da batida do violão ${ }^{10}$ :

\footnotetext{
${ }^{9}$ Dicionário Aurélio

${ }^{10}$ Nesta transcrição, o "v" indica o acento musical (tempo e contratempo), e o sublinhado indica o acento métrico linguístico.
} 


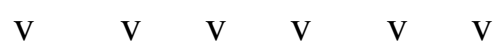

Sou um mulato nato no sentido lato

Na segunda metade, os acentos são todos deslocados:

$\begin{array}{llllll}\mathrm{V} & \mathrm{V} & \mathrm{V} & \mathrm{V} & \mathrm{V} & \mathrm{V}\end{array}$

Mulato democrático do litoral

$\mathrm{Na}$ mesma frase, o compositor une fase e defasagem, simetria e assimetria, ordem e desordem. É mais uma manifestação no plano musical dos conceitos trabalhados nesta faixa e no álbum. Neste caso específico, a transformação recai sobre a interação (desta vez interação rítmica) entre letra e melodia. Até este momento, nesta faixa, as oposições estavam acontecendo na macroestrutura da canção, sobretudo na forma (plano extenso). Aqui temos uma atuação mais profunda, no rudimento do processo de composição da canção, na relação entre sílaba e nota (plano intenso). A instabilidade, nesta faixa, atingiu todos os níveis de profundidade.

$\mathrm{Na}$ quarta exposição do verso entra o acompanhamento da orquestra. Até a sexta exposição o acompanhamento é coerente com a base do violão e com a melodia. A partir da sétima exposição a orquestra se desorganiza, distanciando-se do violão e da voz. Isso marca a entrada de mais um samba de roda. 
Tô doente, bem doente

Da ferida no dente

Mandei chamar o barbeiro

Com a lanceta de ouro

Ferida no mesmo olho

Prumódi dos arengueiros

Eu fiquei sem meu amor

Um corte súbito marca a entrada de uma nova canção:

Vem, comigo no trem da Leste

Peste, vem no trem

Pra buranhem, pra buranhem, pra buranhem-nhem-nhem

$\mathrm{O}$ andamento acelera progressivamente, ao mesmo tempo em que o piano e o violão tornam-se mais marcados. $\mathrm{O}$ arranjo faz uma clara referência ao Trem caipira, de VillaLobos, que também propôs esta "onomatopéia musical". Volta o samba de roda:

Vadeia, vadeia, vadeia

Vadeia vadeia, tô vadiando

(Eu vi a pomba na areia)

Eu vim aqui vou trabalhar

Eu vim aqui vou trabalhar 
Caetano entra repetindo três vezes a expressão "verde vênus". Por alguns instantes, o samba de roda retorna ao primeiro plano. Caetano volta repetindo a frase "ir, ir indo". O acompanhamento dos tímpanos é monótono e o encadeamento rítmico fechado, o que cria uma atmosfera ritualística árida, quase macabra. Mais uma vez, o arranjo é um elemento de extrema importância para a sobremodalização do que está sendo dito. Com o clima disfórico, cria-se a impressão de que o artista está dizendo "ir indo" com o intuito de dizer "ir e não chegar a lugar algum".

Este trecho é especialmente interessante. O samba de roda expõe a oposição trabalho vs ócio. As duas frases principais ("vadeia, tô vadiando" e "eu vim aqui vou trabalhar") são apresentadas na letra sem nenhum elo de ligação. Não há no plano lingüístico nenhuma marca que possa hierarquizar as duas afirmações. Não se apresenta uma polarização fórica que possa estruturar a oposição. A oposição fica por conta da melodia. Os primeiros versos são fortemente asseverativos, responsáveis pela manutenção da estabilidade. O segundo verso "rasga" a tessitura do samba, aumentando o nível de tensão, em uma flagrante oposição. A retomada da primeira parte anula essa tensão, colocando-se como possível "resposta" para essa tensão.

O outro trecho está como que incrustado neste samba de roda, as transições são feitas em fade, sem cortes abruptos. Esta oposição cria um efeito semelhante ao da primeira faixa do disco, ao apresentar duas situações distintas mas musicalmente ligadas. O ritual coletivo e eufórico do samba de roda se opõe ao ritual solitário e disfórico do segundo trecho. 
O último samba de roda é apresentado:

Canarinho da Alemanha, quem matou meu curió?

Canarinho da Alemanha, quem matou meu curió?

odiê, odiá

odiê, odiá

A mulher tava no samba

Mas o homem quer levar

A mulher tava no samba

Mas o homem quer levar

odiê, odiá

odiê, odiá

Eu trabalho o ano inteiro, eu trabalho o ano inteiro,

na estiva de São Paulo

Só pra passar fevereiro em Santo Amaro

Só pra passar fevereiro em Santo Amaro

Mais uma vez há a citação de valores e espaços extremamente próximos aos da origem do autor. Mas desta vez, há um fato novo. No final da exposição do samba de roda, Caetano sobrepõe sua voz ao coro, que logo desaparece, deixando o cantor a capela. É uma passagem extremamente forte. Temos uma impressão clara de que há a presença não de um intérprete, mas sim de um personagem. Mais do que em qualquer parte do LP (com exceção 
da capa), Caetano aqui projeta no discurso um ator imediatamente identificável. O efeito é comparável à mudança de pessoa do discurso: neste trecho, Caetano está de fato falando em primeira pessoa.

Esta faixa retoma praticamente todos os temas e procedimentos elencados no lado A do LP. Ela desenvolve mais uma vez a oposição natureza vs cultura, colocando a primeira como eufórica. Essa oposição é realizada de diversas formas no plano discursivo, através das figuras criadas: Nordeste ("Mulato do litoral", "Santo Amaro") vs Sudeste ("São Paulo"), sertão ("Pacuri”) vs cidade ("Leste-Oeste"). Essa oposição também se manifesta no nível temático, como uma oposição liberdade vs opressão, lazer ("vadeia", "fevereiro") vs trabalho ("trabalho o ano inteiro"). O experimentalismo explicitado na fragmentação do seu arranjo é paralelo ao trabalho nas faixas "De conversa", "Gilberto misterioso" e "De palavra em palavra". A busca pelos valores de origem está presente no projeto visual e nas faixas "Viola, meu bem" e também na "Gilberto misterioso". Estas duas faixas também exploram a imagem da ferrovia. Abrir o lado B com "Sugar cane fields forever" é um importante fator para reforçar a coesão estrutural do LP.

No final da última canção apresentada ocorre um fato até então inédito e de extrema importância. Pela primeira vez no LP temos uma referência topográfica precisa ilustrando a oposição liberdade vs opressão. Ao invés de opor sertão vs cidade, o autor prefere Santo Amaro vs São Paulo. Santo Amaro é a cidade natal do compositor, no recôncavo baiano, e São Paulo é o palco dos principais acontecimentos do tropicalismo. Ao demarcar com mais precisão a posição do sujeito, o compositor apresenta-o em conjunção com um /saber/ até então não experimentado. Este será um importante fator para a performance que será descrita em “Épico”. 


\subsection{Júlia/Moreno}

Segunda faixa do lado B e oitava do álbum, "Júlia/Moreno" é a tentativa de musicalizar uma poesia concreta. Sua letra, aqui transcrita tal como foi apresentada no encarte interno do LP, sugere uma disposição espacial significativa:

uma talvez júlia

uma talvez júlia não

uma talvez júlia não tem

uma talvez júlia não tem nada

uma talvez júlia não tem nada a ver

uma talvez júlia não tem nada a ver com isso

uma júlia

um quiçá moreno

um quiçá moreno nem

um quiçá moreno nem vai

um quiçá moreno nem vai querer

um quiçá moreno nem vai querer saber

um quiçá moreno nem vai querer saber qual era

um moreno 
Segundo Affonso de Romano de Sant'anna, em seu Música popular e Moderna poesia brasileira, a música em questão não comportaria muita "interpretação subjetiva". Ele prossegue, afirmando que "os mais afoitos" viram, na oposição dos nomes Júlia e Moreno a indecisão do compositor acerca do nome de seu filho ${ }^{1}$. No entanto, o escritor termina aí a análise, não se aprofundando na discussão do por ele designado "poema concreto musicado".

A forma escolhida para a música, por mais paradoxal que possa parecer, é a da canção tradicional, completamente "rígida" do ponto de vista métrico. Sua estrutura básica é uma seqüência de quatro acordes, apresentados em um ritmo harmônico bastante acelerado, mas constante, com dois acordes por compasso. Cada verso da letra é apresentado a cada duas seqüências, completando a quadratura de quatro compassos - a mais perfeita e estável estrutura em música. No último verso, quando a frase lingüística se completa, esta ocupa - ou melhor: preenche - totalmente os quatro compassos da seqüência. Um procedimento similar a este já havia sido usado por Caetano Veloso e Gilberto Gil na tropicalíssima canção "Batmakumba", de 1968, apresentada no LP Tropicália, Panis et Circenses.

Uma experiência como esta abre imensas possibilidades de estudo sobre a relação entre a disposição espacial de um poema concretista e seu "correspondente" musical. É importante notar que por "poema concretista" entendemos todo e qualquer poema que tenha na disposição espacial de sua grafia mais um elemento poético a ser considerado. A questão que se coloca aqui se apresenta de forma dupla: por um lado, é preciso analisar de que forma uma grafia espacialmente disposta se manifestaria em um substrato exclusivamente

\footnotetext{
${ }^{1}$ O compositor afirma ter sido exatamente esta a razão da composição (VELOSO, 1997. p.488.)
} 
auditivo. Por outro, como determinar quais arranjos sonoros necessitariam de uma grafia espacialmente elaborada para serem convenientemente transcritos? E quais seriam as variáveis envolvidas nesta operação?

Infelizmente, um estudo aprofundado sobre esta questão fugiria do escopo do presente trabalho. No entanto, faremos uma análise isolada desta canção para podermos entender quais as estratégias empregadas na sua composição, e qual o critério para a grafia da sua letra no encarte interno do LP.

O elemento mais importante na construção da letra de "Júlia/Moreno" é o crescimento progressivo de uma frase inicial ("uma talvez júlia") até a sua apresentação final ("uma talvez júlia não tem nada a ver com isso"). Cada verso é construído a partir do anterior, com o acréscimo de um elemento novo. A primeira parte encerra com um "apêndice", extraído do primeiro verso ("uma júlia”). O início da segunda parte pode ser percebido ao mesmo tempo pela mudança da frase inicial ("um quiçá moreno") mas também pelo recomeço de um novo ciclo de crescimento, até a exposição final ("um quiçá moreno não tem nada a ver com isso"). Assim como na primeira parte, esta segunda encerra com um apêndice extraído do seu primeiro verso ("um moreno"). Isso faz da letra desta canção uma dupla construção que se desenvolve de cima para baixo em cada uma das partes.

A descrição acima não discrimina sua fonte: ela se aplica perfeitamente tanto ao material sonoro quanto ao material gráfico. A única relação que ainda não foi estabelecida entre as duas mídias poderia passar desapercebida por uma análise mais superficial, mas é absolutamente indispensável. Ela decorre da percepção daquilo que nos permite identificar e discriminar uma unidade autônoma: o verso. No texto escrito de uma letra de canção, 
elaborada quase sempre em verso livre, estamos habituados a reconhecer a unidade "verso" (composto por uma quantidade variável de palavras ou fonemas) não só por seu componente semântico, mas também por sua grafia. Geralmente, cada verso ocupa uma linha na página. Ou seja, a identificação é feita graças a uma percepção espacial, que só é possível quando a grafia estabelece uma pauta (métrica?) que sirva de referência. O principal foco de atuação do concretismo é justamente a proposição de novas "pautas", em substituição à tradicional seqüência vertical, de cima para baixo, formada por palavras horizontalmente alinhadas. Essas novas "pautas" podem assumir as formas mais diversas: novas disposições espaciais, tamanho do tipo, outros símbolos gráficos além do alfabeto, cores, etc...

No texto falado, o principal componente não semântico que permite a identificação da unidade "verso" é a pausa. No entanto, as pausas da fala natural são empregadas para separar orações, unidades que nem sempre se confundem com os versos (é por essa razão que raramente a declamação de um poema soa "natural" a ponto de se confundir com a fala). Além disso, a fala natural não tem uma métrica fixa que possa servir de pauta. Esse é um grande entrave para a declamação de um poema concretista construído sobre a elaboração (ou desconstrução) de uma pauta. Já existem inúmeras experiências que propõem, cada uma a seu modo, superar esse problema. É freqüente a associação de cores à timbres de voz, de tamanhos de tipos à intensidade de emissão, por exemplo. ${ }^{2}$

Dentre todos os elementos visuais, o elemento "posição espacial" se destaca na sua relação com um possível correspondente sonoro. Isso decorre de uma característica sua que

\footnotetext{
${ }^{2}$ CAMPOS, Augusto de; CAMPOS, Haroldo de; PIGNATARI, Décio. Teoria da Poesia Concreta. São Paulo: Brasiliense, 1965.
} 
não está presente nos demais. Para a determinar posição, precisamos de uma informação crucial: a distância relativa a um outro ponto de referência. Em outras palavras, para ser possível a determinação de uma posição qualquer, é necessário um eixo. Esse eixo pode ser estabelecido pelas margens físicas do papel (ou qualquer outro substrato material em que o texto esteja grafado), ou pode ser construído pelos diversos elementos grafados. Neste caso, o eixo construído estará inevitavelmente dialogando com o eixo "físico" determinado pelo substrato material. Uma vez estabelecido um eixo de referência, os objetos do texto podem estabelecer inúmeras relações: eles podem estar alinhados, desalinhados ou deslocados. O deslocamento, por sua vez, pode seguir alguma periodicidade, ou pode ser aleatório. A única maneira de se estabelecer um "eixo" com essas características no plano sonoro é lançando mão de propriedades essencialmente musicais: o ritmo, a escala, a harmonia. É por essa razão que a música é indiscutivelmente a melhor amiga da poesia concreta.

Esta faixa do LP trabalha essencialmente com dois sistemas de orientação interligados: a harmonia e o ritmo. No uso cotidiano, a palavra "ritmo" se aproxima do conceito de gênero: falamos em "ritmo de rock", ou "ritmo de samba". No jargão musical, ritmo é uma palavra complexa que sintetiza todos os elementos musicais diretamente relacionados com o tempo. Isto engloba a duração individual de cada nota, a relação de fase e defasagem entre um grupo de notas, o ponto de ataque de cada nota, a organização hierárquica (acento) de cada elemento, além da velocidade do pulso principal (andamento). O uso popular deste conceito embora simplificado não está errado, pois a composição do gênero depende mesmo de todos esses elementos. Na canção que estamos analisando, dois aspectos do ritmo são especialmente importantes: a duração e o ponto de ataque. 
Como vimos anteriormente, a estrutura básica da canção se apóia sobre duas seqüências de quatro acordes, perfazendo um total de quatro compassos. Cada verso cantado inicia no primeiro tempo de cada um desses grupos de quatro compassos (em música usamos o termo "cabeça do compasso"). Em relação ao "eixo" determinado por esta seqüência, temos uma relação de fase: o ponto de ataque de cada verso está perfeitamente alinhado com os demais. Isso justifica plenamente $\mathrm{o}$ alinhamento à esquerda na representação gráfica da letra no encarte.

Assim como na letra, a musicalização de cada verso se dá com a adição de um elemento novo. Cada verso repete as notas do verso anterior, cada uma na mesma altura e com a mesma duração individual, e acrescenta um novo elemento. Isso quer dizer que a partir do verso inicial, a duração total de cada verso aumenta progressivamente. Desta maneira, surgem espaços de "silêncio vocal" de duração inversamente proporcional ao tamanho do verso. Com isso consegue-se musicalmente o efeito do vazio, ou do "espaço em branco" do papel na letra grafada, que diminui a cada verso. Isso justifica um não alinhamento no lado direito do texto. Já a separação entre o último verso ("um moreno") e o restante do texto não encontrou equivalente no plano musical.

A escolha dos acordes que formam a seqüência básica também tem um papel importante para a construção sonora do poema. Esta é a seqüência da primeira parte:

E7M/G\# $\quad G^{\mathrm{o}} \quad \mathrm{F} \# \mathrm{~m} 7 \quad$ B7

Este é um clichê harmônico extremamente freqüente na música brasileira, em especial na bossa-nova e no samba, assim como o que na década de 60 e 70 se 
convencionou chamar de MPB. Absolutamente tonal, ele tem algumas características interessantes que merecem ser observadas. Desenvolvida no tom de Mi maior, a seqüência começa no acorde da tônica (E7M - situação de distensão máxima), que aparece com uma inversão de baixo ( $\mathrm{G \#} \mathrm{-} \mathrm{terça} \mathrm{no} \mathrm{baixo).} \mathrm{Isso} \mathrm{enfraquece} \mathrm{um} \mathrm{pouco} \mathrm{o} \mathrm{poder} \mathrm{de} \mathrm{distensão}$ deste acorde: apesar de oferecer a sensação de repouso, ela não é absoluta - com a inversão, o repouso é atenuado. O segundo acorde $\left(\mathrm{G}^{\mathrm{o}}\right.$ - Sol diminuto) é uma preparação para o último acorde (função dominante). O F\#m7 (Fá sustenido menor com sétima) é um acorde de função subdominante - ele provoca a sensação de "afastamento" - e está interpolado entre o $\mathrm{G}^{\circ}$ e o B7. O último acorde (B7 - Si com sétima) é o acorde de função dominante da tonalidade: tenso, ele prepara o retorno da tônica. Com a repetição da seqüência, o ciclo se fecha. A sensação auditiva é exatamente esta: um ciclo fechado, extremamente coeso, que se repete até o fim da primeira parte. A coesão da seqüência é potencializada pela cadência final (F\#m7 - B7), e também pela presença do baixo que caminha cromaticamente (de semitom em semitom) nos três primeiros acordes. Desta forma, temos o máximo de movimento harmônico (alternância de funções, resolução das dominantes) com o mínimo de salto (baixo cromático). Além disso, o poder de resolução do acorde da tônica, ou seja, sua capacidade de fechar o ciclo, foi atenuada pela inversão. Apesar de resolver satisfatoriamente o acorde dominante que o precede, ele não consegue imprimir uma sensação de "resolução final". Temos a sensação de que a seqüência ainda não chegou ao fim, pois a tensão foi apenas parcialmente relaxada. É um impulso a mais para que o ciclo prossiga em busca de uma resolução final - que não chega jamais.

$\mathrm{O}$ fato de ter uma seqüência que fecha (ainda que parcialmente) um ciclo a cada quatro acordes reforça enormemente a posição da "cabeça do compasso". Além de ser 
determinada pela periodicidade dos pontos de ataque do verso, ela também é determinada harmonicamente. Há uma relação de fase perfeita entre o sistema rítmico e o sistema harmônico. A variação interna da duração da frase melódica se dá dentro de um sistema dinâmico, mas absolutamente estável.

Após a exposição dos seis versos, que ocupam seis grupos de quatro compassos, temos uma mudança tanto na harmonia quanto na estrutura rítmica. O compositor introduz uma pequena seqüência de dois compassos, com um acorde em cada compasso:

\section{G\#7M B7(13)}

Além de provocar uma ruptura tanto do ritmo harmônico de dois acordes por compasso e da seqüência de quatro compassos, a presença do acorde de G\#7M (Sol sustenido com sétima maior) é absolutamente inesperada na tonalidade de Mi maior. Ele também não é um empréstimo modal da tonalidade homônima, Mi menor. Duas interpretações são possíveis: ele pode representar uma rápida modulação para o tom de G\# maior - o B7(13) representaria então a preparação para o retorno da tonalidade original; por outro lado, ele pode ser interpretado como um "acorde diatônico cromaticamente alterado"3. Esta é a designação para um acorde que não pertence ao campo harmônico da tonalidade, mas é construído a partir de uma nota da escala desta tonalidade. Em outras palavras, apesar de ser uma surpresa, existe uma força de coesão que explica sua aparição. Foi esta série de rupturas que nos levou a designar este verso como sendo um apêndice da primeira parte.

\footnotetext{
${ }^{3}$ CHEDIAK, Almir. Harmonia e improvisação. Vol. I. Rio de Janeiro: Lumiar, 1986. p. 116.
} 
A entrada da segunda parte força uma nova interpretação harmônica dos acordes do apêndice. Isto porque ela é exatamente igual à primeira, só que transposta um semitom abaixo, na tonalidade de Mi bemol, situação absolutamente não convencional ${ }^{4}$. Temos então uma cadência deceptiva: o B7, que preparava o retorno à tonalidade de $\mathrm{Mi}$, não "resolve" sua tensão. Já o G\#7M pode ser interpretado como Ab7M (Lá bemol com sétima maior - enarmônico de G\#7M) - acorde que harmoniza perfeitamente com a tonalidade de Mib (ele é o quarto grau de Mib). Temos aqui uma genial combinação de acordes: o G\#7M é surpresa em Mi, mas harmoniza com Mib. O B7 prepara Mi, mas é inesperado em Mib. O resultado é uma verdadeira "trança" ligando duas tonalidades muito próximas.

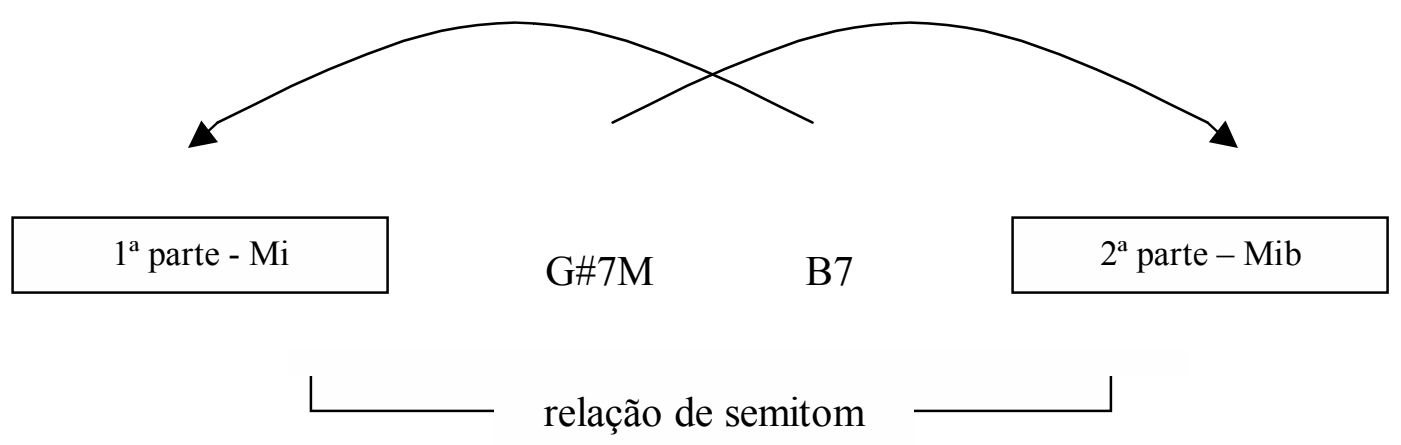

Este inusitado encadeamento ainda tem um poderoso complemento melódico: as melodias das duas partes começam e acabam na mesma nota. Esse movimento involutivo aumenta ainda mais a proximidade e a coesão entre as duas partes. Tudo nesta canção conspira para fazer com que as duas partes, embora claramente distintas, permaneçam visceralmente ligadas.

\footnotetext{
${ }^{4}$ É comum a modulação ascendente por meio tom, às vezes várias vezes seguidas, especialmente no final das canções. Este procedimento aumenta o "nível de energia" da canção, principalmente por levar o intérprete a atingir notas cada vez mais agudas.
} 
A harmonia da segunda parte, como já dissemos, segue exatamente igual à primeira, só que meio tom abaixo:

$\mathrm{Eb} 7 \mathrm{M} / \mathrm{G} \quad \mathrm{Gb}^{\mathrm{o}} \quad \mathrm{Fm} 7 \quad \mathrm{Bb} 7$

O apêndice da segunda parte é feito apenas pelo acorde Fm7 (Fá menor com sétima), que permanece nos dois compassos. A canção então realiza então uma segunda exposição completa, repetindo a primeira e a segunda parte integralmente. Uma única mudança ocorre no apêndice da segunda parte. Ele é composto pelo mesmo Fm7, que dura apenas um compasso, e um E7M (Mi com sétima maior), durando dois compassos. Esse acorde é o primeiro acorde da música, só que sem a inversão. Ele seria uma perfeita resolução final para a primeira parte. No entanto, ao aparecer na tonalidade de Mib menor (estamos no apêndice da segunda parte), ele soa um Fb7M (Fá bemol com sétima maior), que na tonalidade de Mib é um bII7M - substituto da subdominante menor - acorde relativamente tenso que espera resolução em $\mathrm{Mib}^{5}$. Nesse interessante jogo, Caetano consegue deixar para o final da canção uma tensão não resolvida usando exatamente o acorde de resolução da primeira parte.

As duas partes iniciam com o uso de termos que expressam o sentido de dúvida ("talvez" e "quiçá"). Apesar de não aparecer com maiúscula, "júlia” é imediatamente reconhecido como um nome próprio. O termo "moreno" tanto poderia ser um nome próprio quanto um adjetivo. No entanto, a simetria da letra aponta para a primeira possibilidade. A construção do primeiro verso de cada parte apresenta então dois sujeitos

\footnotetext{
${ }^{5}$ CHEDIAK, Almir. Harmonia e Improvisação. vol. I, p. 96
} 
potenciais, Júlia e Moreno. Já no primeiro verso, temos duas manifestações de incerteza acompanhando esses dois sujeitos: "talvez" e "quiçá", e o uso do pronome indeterminado "uma" e "um". Os dois versos encerram com uma negativa: "não tem nada a ver com isso" e "nem vai querer saber qual era". Os sujeitos permanecem sem qualquer laço juntivo com o objeto designado pelo pronome "isso". Esse objeto parece ser a própria canção, que se materializa à medida que os versos vão sendo construídos. No apêndice, logo após o verso ser finalmente apresentado por completo, os sujeitos são reapresentados ("uma júlia", "um moreno"), no seu grau máximo de concretude, apesar do pronome indeterminado.

A interpretação semiótica deste procedimento é ainda mais interessante. Como vimos, o tonema é um importante elemento para a construção do sentido da frase melódica. Em uma melodia que cresce progressivamente, temos a cada exposição a possibilidade de uma mudança tanto no perfil como no tonema de cada verso. Até a chegada do verso final, onde a melodia se apresenta por completo, temos um aumento gradativo de expectativa. Apesar da desaceleração obtida com a repetição da parte já exposta, há um grande grau de surpresa, com a apresentação do novo elemento melódico e definição do tonema do verso. Até a exposição final, o que rege a melodia é - assim como a letra - a indefinição.

A melodia da primeira parte forma uma frase ascendente composta por cinco graus imediatos ("Uma talvez júlia não tem nada a"). Há um acúmulo progressivo de tensão que colapsa com o salto para o grave ("ver com"), e o reequilíbrio final ("isso"). O apêndice é formado por um salto para o grave, com o imediato retorno ("uma júlia"). O sentido global é o de suspensão. A segunda parte também é uma seqüência ascendente, só que interrompida duas vezes ("nem vai" e "saber"). A última interrupção acaba com um salto que atinge o pico da tessitura. Esta melodia é visivelmente mais tensa e também mais 
fragmentada que a primeira. Três versos terminam em tonema descendente, o que confere um grau resolutivo à melodia: "um quiçá moreno nem”, "um quiçá moreno nem vai”, “um quiçá moreno nem vai querer saber". Os outros três (dentre eles o verso final) acabam com tonema ascendente, alcançado através de um salto, o que acentua ainda mais o caráter inconclusivo destes fragmentos. No verso final, isso é ainda mais acentuado pelo fato do salto alcançar o pico da tessitura. O aspecto geral desta melodia ressoa diretamente com alguns dos elementos analisados na letra. Temos aqui uma tensão gerada tanto pela incerteza da frase que se constrói aos poucos, como pelo perfil fragmentado da melodia e sua finalização em tonema ascendente. Toda a expectativa criada pela segunda parte deságua no seu apêndice, melodicamente idêntico ao primeiro. Assim como na harmonia, não há uma resolução completa desta expectativa - apenas o retorno ao nível de suspensão anterior. Há um alinhamento perfeito entre letra, melodia e harmonia, tornando essa canção extremamente coesa e eficaz.

Como vimos, o crescimento progressivo do verso cantado deixa um "espaço em branco" de tamanho inversamente proporcional. No arranjo desta canção, este espaço foi preenchido em ambas as partes por um solo improvisado. A diferenciação se dá principalmente com a escolha do instrumento solista em cada parte. Na primeira parte, o improviso fica por conta da flauta transversal, instrumento de timbre doce e suave. Na segunda, temos uma guitarra elétrica com distorção, que produz um timbre mais áspero e um solo mais rítmico e agressivo. Há um acréscimo de densidade em relação à primeira parte que sustenta plenamente a oposição desta melodia, mais agressiva, com a primeira, mais suspensiva. Há uma mudança na levada da bateria que também contribui com o aumento da densidade desta segunda parte. 
Dentro de um contexto construído quase que exclusivamente sobre a proximidade e contigüidade, cada pequena alteração ganha proporções maiores. No plano lingüístico, a única mudança significativa na passagem da primeira parte para a segunda é a do sujeito: “júlia" na primeira parte e "moreno" na segunda. É também uma mudança de gênero: passamos do feminino para o masculino. Essa transformação ganha um reforço sensorial no arranjo, cuidadosamente elaborado. A oposição feminino vs masculino é acompanhada da oposição doce vs áspero e suave vs agressivo, a partir dos solos da flauta e da guitarra, respectivamente. Este cuidado aumenta ainda mais a eficácia desta canção, ampliando a sua capacidade de persuasão - tudo o que se ouve confirma plenamente o que é dito.

Dentro do contexto do LP, essa faixa atualiza algumas questões colocadas pelas outras faixas e também pelo material visual. Temos aqui uma grande ênfase no tema do desdobramento. Esse desdobramento é de certa forma oposto ao apresentado pela faixa "De palavra em palavra". Naquela, o compositor partiu de uma palavra complexa e dela extraiu seus fragmentos, na forma de palavras menores. Aqui, partimos de um pequeno motivo, ao qual são acrescentados fragmentos até a composição do todo final.

Também temos aqui uma fina ressonância com a capa do LP. A indecisão do gênero masculino vs feminino é imediatamente associada à idéia de gestação. A ato de criação aqui apresentado é sem dúvida nenhuma um ato visceral. Há um deslocamento do /fazer/, representado pela performance da criação, para a instância do /ser/, para a essência da criação, e sua reverberação nas estruturas da canção. Outro fato também merece atenção: nenhum sujeito é de fato instaurado - tudo transcorre permeado por um /não saber ser/. Como os sujeitos são hipotéticos, não é possível dizer se a indecisão manifestada é interna ou externa. Fica com isso no ar a possibilidade da indecisão "existencial" apresentada ser 
uma indecisão relativa a orientação sexual. Como isso, temos um pequeno detalhe paralelo à expressão (que também é de duplo sentido) inscrita no encarte central: "um disco para entendidos".

\begin{tabular}{|cc|}
\hline \multicolumn{2}{|c|}{} \\
\hline \multicolumn{2}{|c|}{ nada a } \\
\hline \multicolumn{2}{|c|}{ não tem } \\
\hline Júlia \\
\hline \multicolumn{2}{|c|}{ isso } \\
\hline talvez & \\
\hline Uma & Júlia \\
\hline \multicolumn{3}{|c|}{} \\
\hline
\end{tabular}

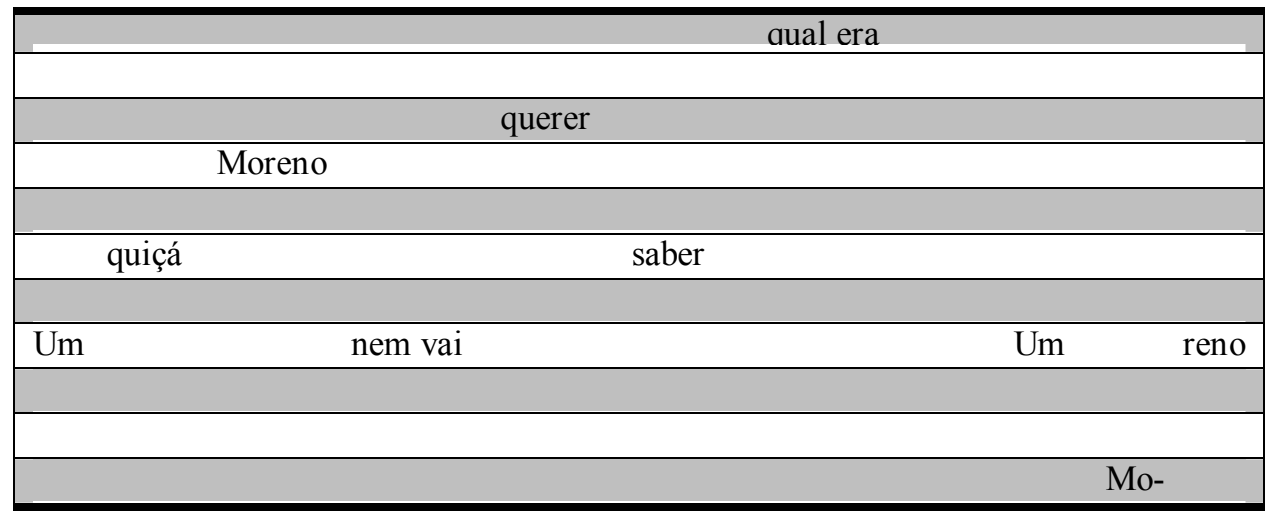




\section{9. Épico}

$\mathrm{Na}$ imensa maioria das composições, o título é extraído da própria letra. Muitas vezes, trata-se de uma pequena frase ou palavra que sintetiza o que está sendo dito. No caso da "Épico", o título traz um acréscimo de sentido importante para a compreensão da faixa. O gênero épico é tradicionalmente definido como uma narrativa de feitos gloriosos, realizados por heróis, inspirados por deuses e entes mitológicos. A narrativa épica é sempre maniqueísta: a luta do herói representa a luta entre o bem e o mal, dentro de um sistema ideológico que representa uma verdade absoluta e incontestável. O traço épico pode ser encontrado em diversas manifestações modernas. O seriado protagonizado pelo "agente 007", o "super-homem", "Star Wars" e os "westerns" americanos são exemplos dos épicos modernos. É importante notar que o centro da narrativa épica é a ação do seu herói, e esta é sempre uma ação restauradora. Graças a ela, os valores ideológicos são restaurados e perpetuados. A escolha deste título nos obriga a interpretar a letra desta canção à luz dessas novas informações.

Ê, saudade,

Todo mundo protestando contra a poluição, até as revistas de Walt Disney contra a poluição

\section{Ê, Hermeto}

Smetak, Smetak, \& Musak, Smetak, 


$$
\begin{aligned}
& \hat{\mathrm{E}} \text {, cidade, } \\
& \text { sinto calor, sinto, frio, nordestino }{ }^{1} \text { do Brasil? } \\
& \text { vivo entre São Paulo e Rio porque não posso chorar } \\
& \text { destino eu faço não peço, tenho direito ao avesso } \\
& \text { botei todos os fracassos nas paradas de sucesso } \\
& \hat{\mathrm{E}}, \text { João }
\end{aligned}
$$

A grandiosidade épica sugerida pelo título é imediatamente recoberta pelo arranjo orquestral da introdução. Composto sobretudo com tímpanos e metais, instrumentos de ataque forte e preciso, este trecho remete diretamente aos arranjos dos filmes de ação, em especial “GoldFinger”, protagonizado por James Bond. Os tímpanos são também mais uma referência ao épico de Stanley Kubrick, “2001, uma odisséia no espaço”. Há portanto uma aproximação não só temática (pelo uso do título “épico”) mas também estética.

O tom majestático da introdução contrasta nitidamente com a melodia suavemente apresentada pela flauta transversal. É interessante notar que a flauta expõe exatamente o tema inicial que será cantado pelo intérprete. Há aqui uma antecipação que quebra a surpresa do tema cantado (quando surge a voz, a melodia já é uma repetição). Essa

\footnotetext{
${ }^{1} \mathrm{O}$ grifo está de acordo com o incarte interno.
} 
antecipação ressoa como um procedimento típico do discurso épico: a desaceleração (narrador e leitor já conhecem de antemão o desfecho da narrativa). A desaceleração da repetição esvazia o conteúdo dramático da surpresa, além de aumentar o teor de "verdade absoluta" atribuído ao que será dito pelo intérprete.

É interessante notar que o arranjo desta faixa tem três protagonistas claramente identificados: a orquestra, o intérprete, e os ruídos de buzinas e carros. Os dois últimos são apresentados sempre juntos, construindo a ilusão de que se trata de uma gravação ao vivo. É interessante notar que esses três protagonistas são descritos nos créditos. O intérprete é evidentemente o compositor do álbum, e o arranjo de orquestra desta canção é atribuído a Rogério Duprat. Os ruídos são identificados como sendo oriundos da “Avenida São Luiz”. Essa é a segunda citação direta a um local específico no álbum. Essa descrição também acontece na letra: "vivo entre São Paulo e Rio". Com isso, o compositor consegue uma ancoragem que promove um efeito de sentido de realidade em um grau até então não explorado neste LP.

A estrutura deste arranjo opõe nitidamente seções de grande intensidade e densidade e outras mais suaves e esparsas. Essa oposição não se dá apenas pelas intervenções da orquestra. Na interpretação vocal, temos uma oposição de forte vs fraco acompanhada de uma separação dos canais esquerdo e direito. As duas primeiras estrofes são cantadas com menos intensidade, com a voz isolada no canal direito. O mesmo acontece com a última frase (que parece ser uma estrofe interrompida). As intervenções da orquestra (no canal esquerdo) são esparsas e de fraca intensidade. A terceira e quarta estrofes são cantadas em volume nitidamente maior, com a voz isolada no canal esquerdo, e as intervenções da orquestra são sensivelmente mais agressivas. 
Podemos esquematizar o arranjo da faixa da seguinte maneira:

\begin{tabular}{|c|c|c|c|}
\hline $\begin{array}{l}\text { Intro orquestra } \\
\text { Forte }\end{array}$ & $\begin{array}{l}\text { tema flauta } \\
\text { fraco }\end{array}$ & $\begin{array}{l}\text { estrofes } 1 \text { e } 2 \\
\text { fraco }\end{array}$ & $\begin{array}{l}\text { Interlúdio orquestral } \\
\text { Forte }\end{array}$ \\
\hline $\begin{array}{l}\text { estrofes } 3 \text { e } 4 \\
\text { Forte }\end{array}$ & $\begin{array}{l}\text { Interlúdio orquestral } \\
\text { Forte }\end{array}$ & $\begin{array}{l}\text { estrofe } 5 \text { - flauta } \\
\text { fraco }\end{array}$ & $\begin{array}{l}\text { Final (repete intro) } \\
\text { Forte }\end{array}$ \\
\hline
\end{tabular}

Tanto a estrutura da melodia quanto os aspectos da interpretação vocal remetem diretamente para a figura do repentista. Há aqui uma composição pictográfica: o acompanhamento das "buzinas e canos de descarga" situam precisamente o personagem, colocando-o a beira de uma avenida de um centro urbano. Estabelecida o tempo inteiro sobre um mesmo acorde, a melodia é típica do repente. Embora não completamente definida, devido a sua pequena tessitura, ela remete para a escala Lídio b7, cuja maior característica é o intervalo \#11 (décima primeira aumentada), que propicia o típico "sabor" nordestino. Podemos observar a utilização quase exclusiva de graus imediatos, intercalados por alguns saltos intervalares. Todos os tonemas são descendentes, o que enfatiza o caráter afirmativo do texto lingüístico. O tema forma uma seqüência de parábolas com concavidade para baixo, fazendo um ciclo contínuo de acúmulo e dissolução de tensão. Apesar de ter características suficientes para ser imediatamente reconhecida como um repente, a ausência do acompanhamento rítmico provoca um interessante efeito. Normalmente, o repente é acompanhado pela viola, podendo ainda se aproximar de ritmos como o xote e o baião se houver uma base percussiva (tradicionalmente triângulo e 
zabumba). ${ }^{2} \mathrm{O}$ caráter passional da melodia normalmente é residual e se apóia sobretudo sobre a interpretação, com o alongamento das vogais no final das estrofes. Nesta faixa, o canto não é ritmicamente preciso, mas também não é totalmente livre. Tudo ocorre como se ele estivesse deslizando suavemente em torno de uma estrutura rítmica de fundo que não é evidenciada, exatamente como no canto gregoriano. Por muito tempo, a Igreja proibiu o uso de instrumentos no acompanhamento do canto de louvação. Assim, sem marcação rítmica e sem acompanhamento instrumental, e preso à escala modal (que não opõe os movimentos de tensão/resolução da harmonia tonal), o canto gregoriano assume um ar celestial. Caetano consegue aqui uma estranha harmonização entre o canto modal nordestino desta faixa e os ruídos dos carros e buzinas. Apesar do choque conceitual, o resultado final é extremamente consistente: o ouvido aceita imediatamente os ruídos como cenário natural da cena representada. Surpreendentemente, o artificialismo fica deslocado para as intervenções da orquestra, e não para os sons da avenida.

$\mathrm{Na}$ primeira estrofe, o narrador apresenta diretamente o conflito: o protesto da população contra a poluição. Mais uma vez fica clara a intenção de compor uma cena multissensorial: a poluição é mencionada verbalmente, mas aparece concomitantemente no arranjo da orquestra, nas buzinas do carro (poluição sonora), e na imagem dos canos de descarga (poluição do ar). A inclusão das "revistas de Walt Disney" no bloco que protesta contra a poluição é também bastante interessante. A obra de Walt Disney é um símbolo complexo do capitalismo norte-americano. Ela representa um empreendimento milionário e extremamente bem sucedido da indústria de cultura de massa, cujo produto - assim como a música popular - é freqüentemente associado à idéia de lixo cultural. Por outro lado, ela

\footnotetext{
${ }^{2}$ Cf. ANDRADE, Mário de. Dicionário musical brasileiro.Belo Horizonte: Itatiaia, 1999.
} 
realiza o resgate de diversas obras de autores consagrados da literatura infantil. Sua participação no bloco dos que protestam contra a poluição tanto pode ser uma simples incoerência como também uma lúcida atitude autocrítica desta indústria.

Ao admitir que este LP compõe uma unidade, apesar da diversidade do material apresentado nas diversas faixas, podemos fazer uma outra interpretação do termo “poluição" nesta faixa. Até então, o tema central de quase todas as faixas apoiava-se sobre a oposição valores internos vs valores externos, alinhada a outras oposições: identidade vs perda de identidade, liberdade vs opressão, sertão vs cidade, todas elas sobredeterminadas pela oposição eufórico vs disfórico. Desta maneira, a poluição aqui pode muito bem representar o sentido de "valores externos", que por sua vez implica em outros: perda de identidade e opressão. Neste contexto, a citação a Walt Disney, o elemento externo, dentro do bloco opositor, constrói um paradoxo que tem o poder de diluir o maniqueísmo das oposições trabalhadas até então. Pela primeira vez, o representante dos valores externos não é visto como um elemento disfórico. Mais do que um inimigo, ele é visto (mesmo que com cautela, com o uso da expressão "até") como um aliado.

A epopéia clássica é composta de três partes distintas: proposição, invocação e narração. Ao apresentar o problema, na primeira estrofe, o compositor fez a sua proposição: a revolta da população contra a poluição, símbolo do desenvolvimento industrial e da modernidade. Como vimos, o material é trabalhado dialeticamente, com a introdução do elemento aparentemente opositor (que é simbolizado pelas "revistas de Walt Disney") dentro da própria proposição. Na segunda estrofe, temos a invocação: o "bruxo dos sons" Hermeto Pascoal é elevado aqui ao posto de divindade inspiradora. Nascido em 1936, no município de Lagoa da Canoa, em Alagoas, Hermeto Pascoal já carregava em 1970 o ethos 
de ser maior músico do Brasil. Nada poderia ser mais livre e criativo que sua relação com a música: para ele, a arte dos sons não impõe qualquer tipo de limite, seja ele estrutural, conceitual ou timbrístico. Suas composições e interpretações transcendem qualquer teoria, assim como a sonoridade por ele buscada transcende os limites dos instrumentos convencionais: sua música tanto pode brotar de um piano, como de instrumentos feitos a partir de sucata, ou até mesmo de animais. Muito mais do que um virtuoso agindo dentro de um campo predeterminado, Hermeto Pascoal é um inquieto pesquisador do som.

Esse é o elo que o une a Walter Smetak, músico, compositor, filósofo e pesquisador sueco. Smetak veio residir no Brasil em 1936, e mudou-se para Salvador em 1957, para atuar na Universidade Federal da Bahia. Ele foi um dos poucos adeptos do microtonalismo no Brasil. O microtonalismo transcende a divisão da escala em semitons, aumentando exponencialmente o número de possibilidades de combinações dentro da escala ocidental. Mais do que colocar novas notas à disposição, esse tipo de abordagem esbarra em questões mais profundas, sobre a própria essência do som e da sua percepção pelo homem. Há declarações de Smetak afirmando seu interesse pelo "mistério do Som". Esse interesse o motivou a construir mais de 150 esculturas-instrumentos, apelidadas de "plásticas sonoras". Sua citação é também mais uma referência de Caetano ao que lhe é próximo, pois além de amigo íntimo, foi Caetano quem o ajudou a produzir seu primeiro LP, em 1974. É importante salientar a diferença entre o microtonalismo e a experiência de valorização dos comas efetuada em "Gilberto misterioso". Enquanto o microtonalismo propõe a instalação de um novo sistema de organização dos sons, estável e matematicamente definido, a experiência de Caetano atua tão somente na direção de desestabilizar o sistema em que se insere. 
A introdução destes dois personagens no Araçá Azul ressalta o tema constante de busca da origem, da essência, do mistério. Mas assim como na primeira estrofe, essas duas entidades ressoam com a presença de um outro elemento, a "Musak". Este termo é utilizado para designar um tipo de composição sem valor, descartável, associado ao que popularmente é chamado de "música de elevador". Dentro do contexto do álbum, e especificamente desta faixa, é possível concluir que "Musak" aqui representa toda a cultura de massa, ou mais ainda, todo o "lixo cultural" que já tinha sido mencionado na primeira estrofe. Mais uma vez, não se faz uma confrontação do tipo eufórico vs disfórico: os termos são simplesmente justapostos pela conjunção “e”. É interessante notar que no encarte esta conjunção é grafada como "\&", enfatizando a presença do elemento externo, só que desta vez utilizado justamente como elemento conjuntivo. Ao invés da oposição, que vinha se manifestando em quase todas as faixas, estamos observando aqui uma verdadeira absorção. Há também uma sutil ironia ressoando entre o termo "Musak" e as "musas" do épico clássico, como se aquele fosse uma distorção lexical destas. Afinal, "Musak" é exatamente o termo "musa", com a adição da letra "k", inexistente no nosso alfabeto (mais uma justaposição de um elemento externo).

O interlúdio orquestral mostra que estamos diante de uma passagem (em música chamamos de "ponte"). É a indicação de que teremos uma mudança de parte, que normalmente é acompanhada de uma mudança semântica no texto cantado. De fato, a segunda parte, composta pelas estrofes três e quatro, apresenta como já vimos algumas mudanças sonoras, em especial o aumento da intensidade na interpretação. E pela primeira vez na letra temos uma debreagem enunciativa, instaurando um "eu" ("nordestino do Brasil"), “aqui” (“entre São Paulo e Rio"), e "agora" (presente do indicativo). A narração 
em primeira pessoa coloca o "herói" em primeiro plano, assim como o aumento de intensidade coloca a voz em primeiro plano no arranjo. Por um lado, temos uma retomada da problemática antiga, opondo os valores dentro do mesmo eixo: sertão vs cidade, liberdade vs opressão ("não posso"). Por outro, temos uma atualização de todos esses valores: o sertão agora é o "nordestino do Brasil", a cidade é "São Paulo" (definida na letra e sugerida nos créditos também). A oposição relatada neste discurso, embora ainda seja a mesma, está mais ancorada, menos abstrata. No encarte, a grafia de "nordestino" ressaltou o componente "destino" da palavra, e termina a frase com um ponto de interrogação. Além da debreagem enunciativa e da actorialização, temos na segunda estrofe o uso da palavra “razão". Há um questionamento claro sobre a imutabilidade das oposições estabelecidas. Esse questionamento só é possível graças ao ganho de competência realizado pelo sujeito apresentado nesta faixa do álbum.

A quarta estrofe narra a ação do sujeito/herói. O retirante muda a sua sorte ("sucesso") gravando seus fracassos num disco (símbolo da industrialização), ciente de estar no comando do seu destino ("faço, não peço"), virando (“o avesso") o rumo de sua vida. É interessante notar que ele "troca" o acompanhamento da viola pelo acompanhamento dos ruídos da avenida e buzinas de carro. Dessa forma, todo o estado disjuntivo inicial se transforma em programa de competência desse sujeito para realizar a sua performance. Os elementos externos não são mais anti-sujeitos, mas sim coadjuvantes da ação. Essa situação representa um passo além na aceitação dos valores externos, uma superação da oposição conjunção vs disjunção. A sanção negativa da situação disfórica transforma-se em programa de competência para a realização da performance. O sujeito não luta contra os valores disfóricos, mas os utiliza para conjuntar-se com os valores 
eufóricos. Nada poderia representar melhor a proposta tropicalista. Nesta faixa, o procedimento tropicalista é colocado como o grande fator revolucionário capaz de subverter a ordem imposta. Este é o "começo" cantado no início da quarta estrofe.

O último verso retoma as características sonoras das duas primeiras estrofes. A repetição destas características sugere ao mesmo tempo o fechamento de um ciclo e um recomeço. A chave para a compreensão da citação de "João" está no tema apresentado pela flauta, duplamente escondido. Por um lado, temos uma repetição de um timbre - a flauta já havia sido apresentada como introdução à voz. Por outro lado, as cinco primeiras notas do tema aqui exposto coincidem com o tema principal da melodia entoada. As quatro notas restantes caracterizam o início de "Desafinado", canção de Tom Jobim imortalizada na voz de João Gilberto. Esta é uma maneira extremamente sutil e elegante de descrever a interpretação tropicalista do fenômeno da bossa-nova no Brasil. Assim apresentada, a bossa nova é vista como uma aceitação complexa da modernidade. Mais do que uma aceitação, ela funda uma modernidade, que incorpora criativamente (ao analisar esta faixa, poderíamos dizer: ardilosamente) os elementos externos, a poluição dos timbres e das notas “desafinadas". A opção por uma citação “escondida" no final da canção também não é casual. Esta é uma maneira de afirmar que todos os elementos aqui descritos já estavam “escondidos” na música de João Gilberto. Ao invés de requerer um status de originalidade para os elementos apresentados, o compositor dá a faixa um caráter de revelação. A performance aqui é subordinada ao momento veridictório desta revelação. 


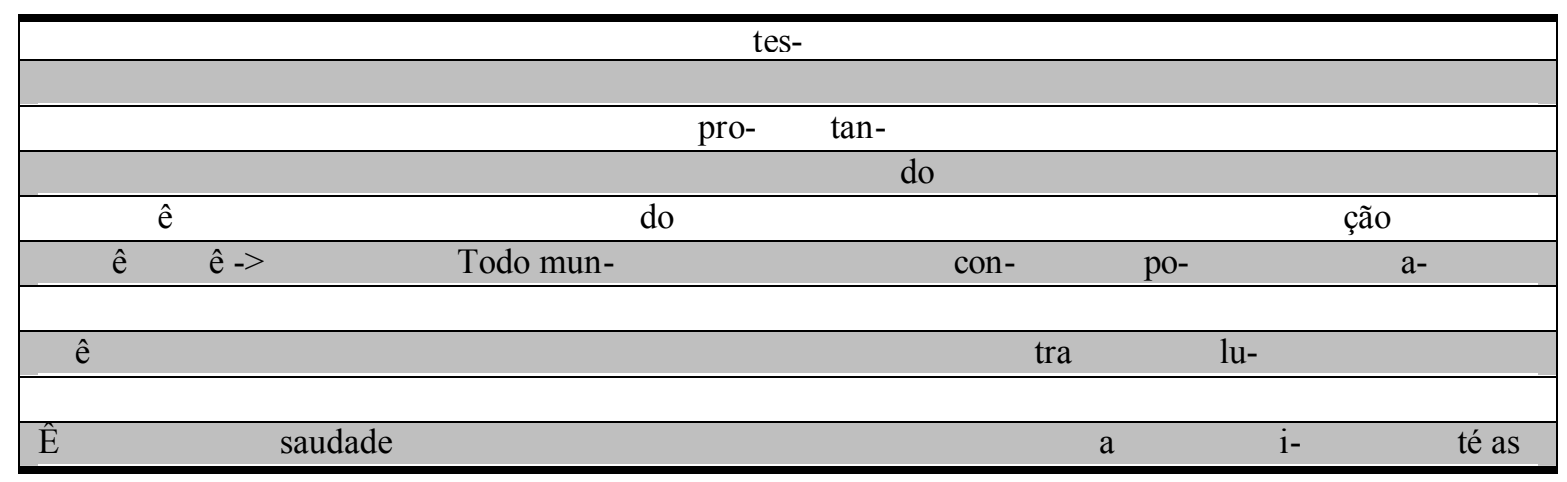

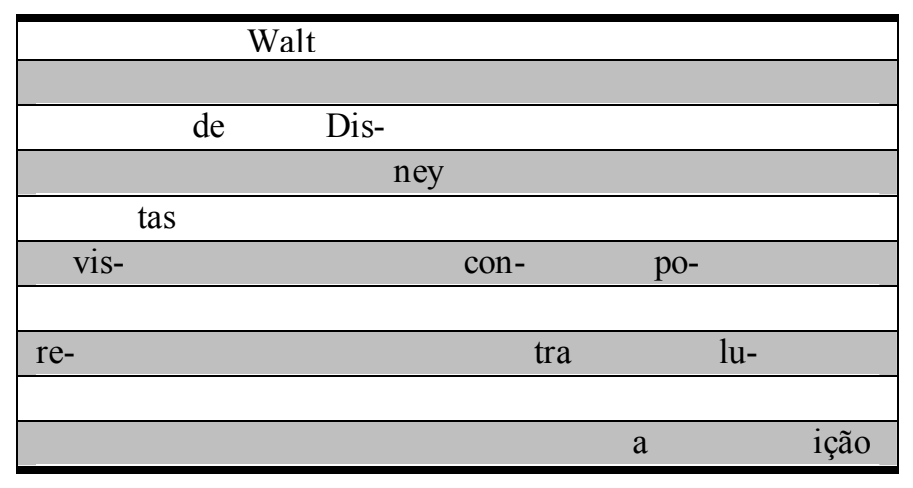

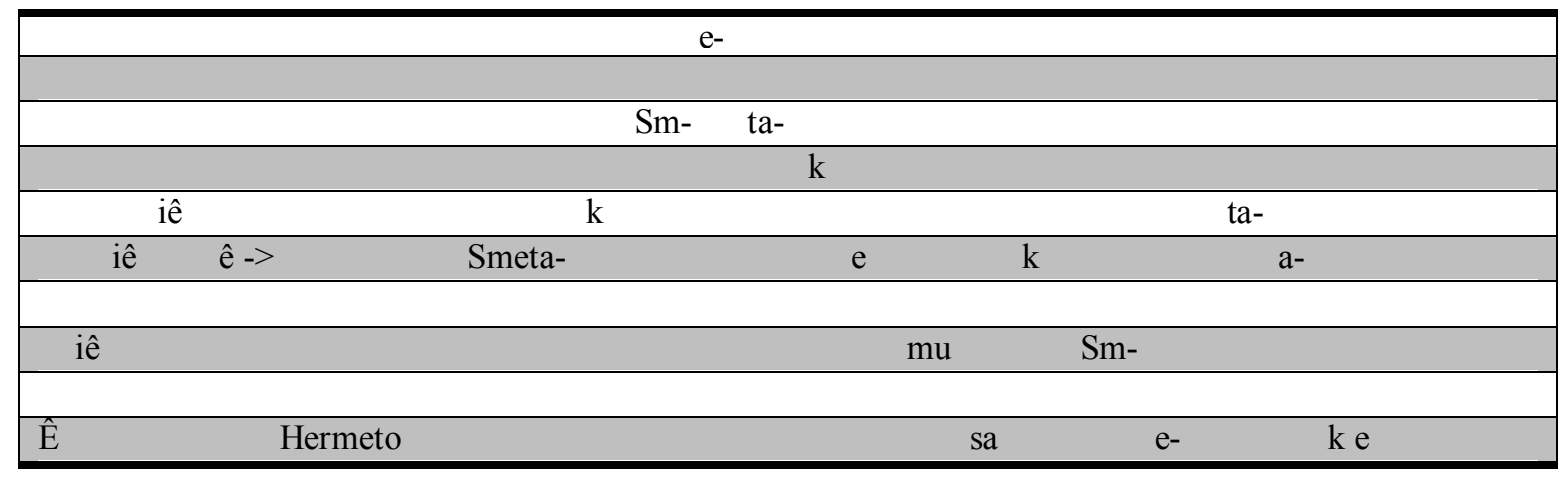




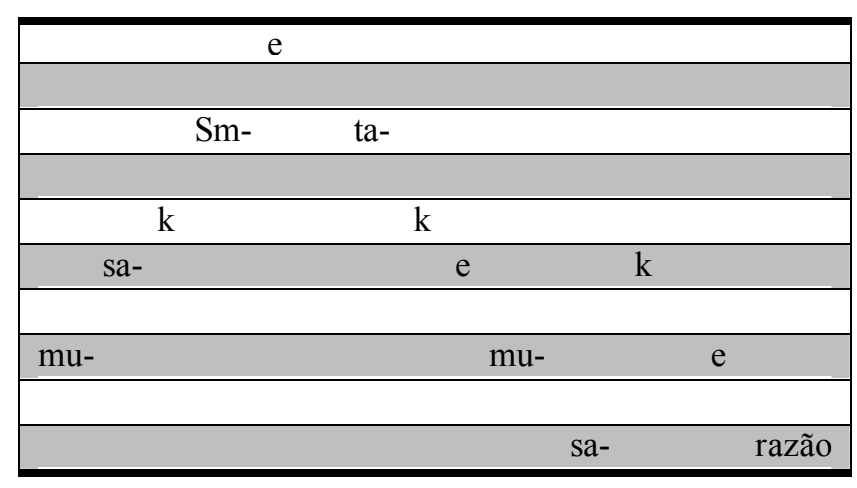

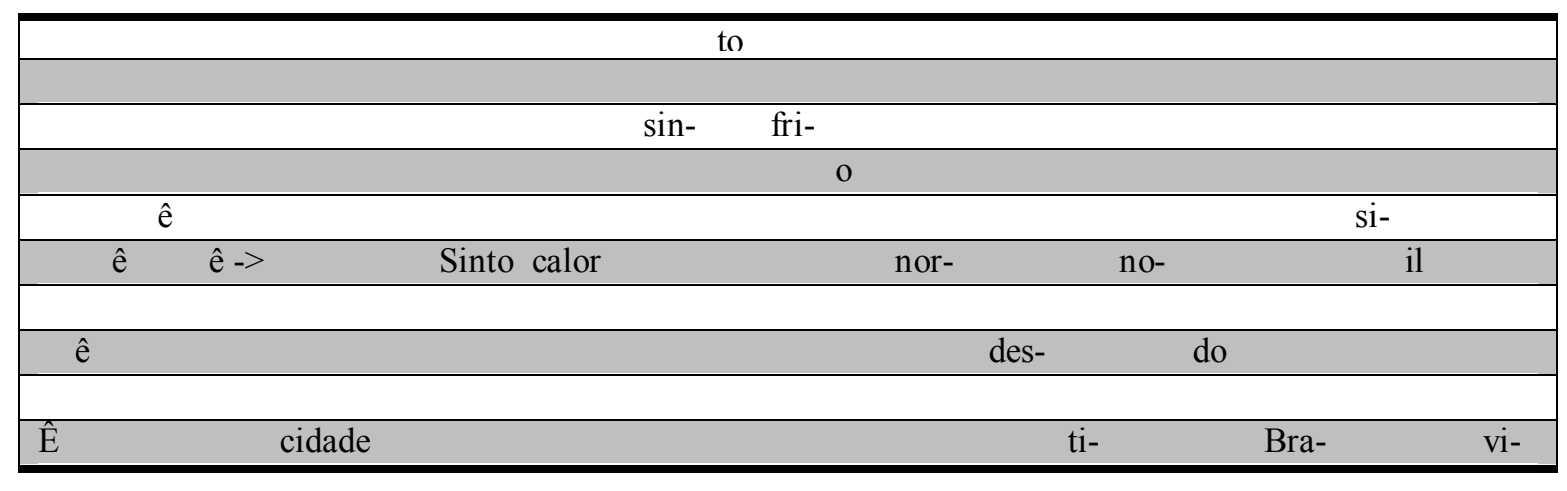

\begin{tabular}{|c|c|c|}
\hline \multicolumn{3}{|c|}{ lo e } \\
\hline Pau- & ri- & \\
\hline \multicolumn{3}{|c|}{ o } \\
\hline \multicolumn{3}{|l|}{ São } \\
\hline tre & \multicolumn{2}{|r|}{ pos- } \\
\hline \multirow[t]{2}{*}{ vo en- } & que & so \\
\hline & \multicolumn{2}{|c|}{ não chorar } \\
\hline
\end{tabular}




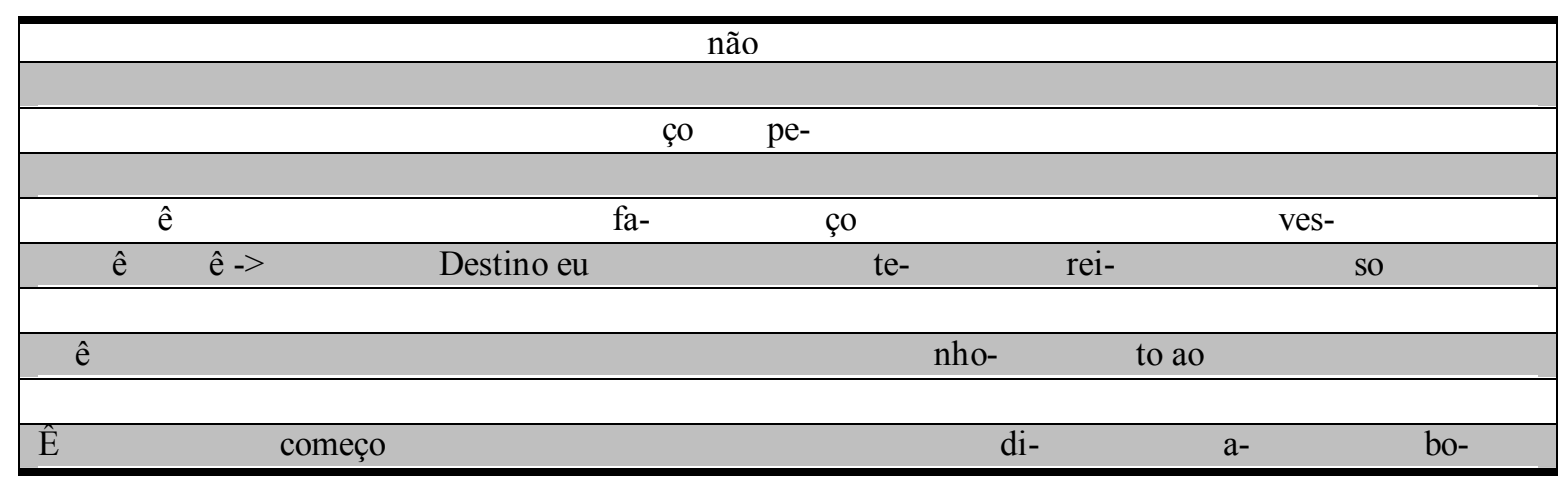

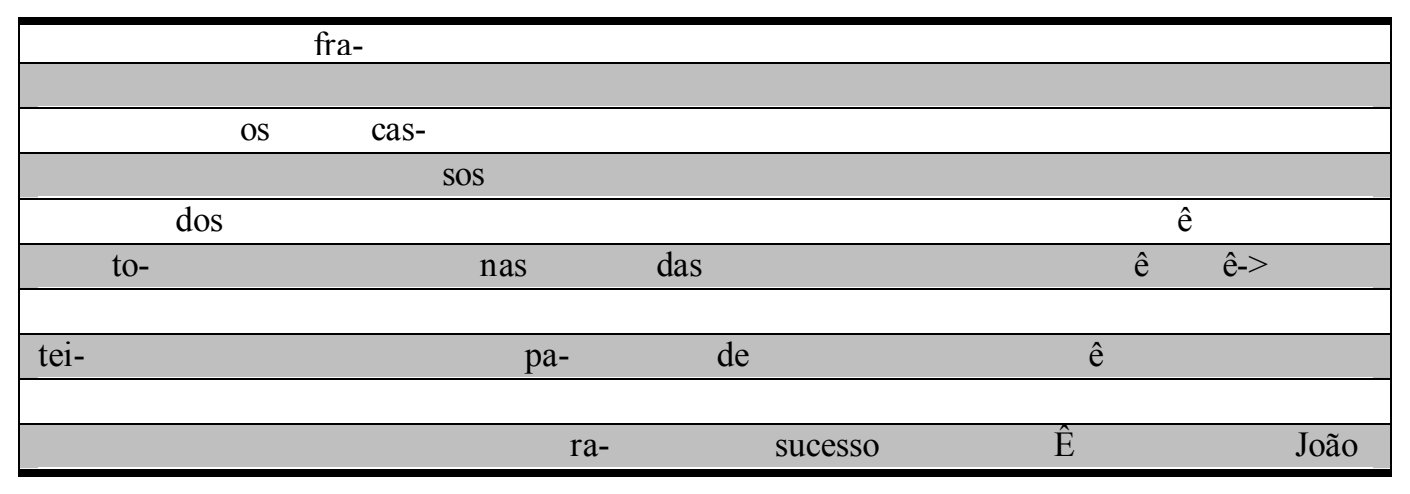


4.10. Araçá azul

Araçá azul é sonho e segredo

Não é segredo

Araçá azul fica sendo

O nome mais belo do medo

Com fé em Deus, eu não vou morrer tão cedo

Com fé em Deus, eu não vou morrer tão cedo

Com fé em Deus, eu não vou morrer tão cedo

Araçá azul é brinquedo

Esta faixa é uma bela e curta canção de melodia relativamente simples, realçada pela harmonia muito bem elaborada do seu acompanhamento de violão. A primeira parte é composta por uma seqüência de dois acordes. O primeiro deles é formado pelas notas Mi, Sol\#, Sol e Si. A partir de sua fundamental, temos os intervalos de terça maior, terça menor e quinta justa. A quinta justa é um intervalo extremamente consoante (é o segundo harmônico da série harmônica). Justamente por isso, sua presença na construção dos acordes é facultativa, já que ela não promove nenhuma mudança substancial nos acordes em que aparece. Já a terça é o intervalo que caracteriza duas categorias diferentes de acordes: o maior e o menor. Nesta faixa, o acorde utilizado apresenta as duas terças, fato absolutamente não convencional na harmonização da música popular. Em determinados 
contextos, quando temos a terça maior (no caso Sol\#) junto com a terça menor (Sol), esta última pode ser interpretada como \#9 (nona aumentada), enarmônica da terça menor. No entanto, isso só ocorre em acordes dominantes, maiores com sétima menor. Nesta canção, o efeito é de um acorde híbrido, ambíguo quanto a sua classificação.

No campo da harmonia, muito pode ser dito em relação à oposição maior vs menor. Eles pertencem a escalas diferentes, definem campos harmônicos diferentes e admitem tensões diferentes: a teoria musical tem ferramentas mais do que suficientes para abordar a questão do ponto de vista técnico. No entanto, ao tentar definir a diferença entre o efeito de sentido que cada um desses acordes produz ao ser ouvido, entramos em um perigoso terreno subjetivo. É freqüente a associação da oposição alegre vs triste em relação à característica maior e menor destes acordes. Mas essa oposição pode facilmente ser destruída por outros elementos musicais (andamento, melodia) o que comprova que esta acepção não pode ser verdadeira. No livro $O$ som e o sentido, de José Miguel Wisnik, temos uma interessante definição sobre o ethos dos modos gregos, atribuída a Ricardo Breim. Este classifica os sete modos gregos em uma seqüência que vai do mais aberto ao mais fechado, ou seja, a partir dos que têm os maiores intervalos em relação à fundamental até os que têm os menores intervalos. Segundo ele, esta oposição entre aberto vs fechado pode ser associada a uma relação luminoso vs escuro. ${ }^{1}$ Embora esta definição tenha sido utilizada para classificar escalas e não acordes, é interessante notar que as três escalas mais abertas formam acordes maiores, enquanto as três escalas mais fechadas formam acordes menores. A oposição maior vs menor pode então ser estabelecida sobre um aspecto de brilho: luminoso vs escuro.

\footnotetext{
${ }^{1}$ Cf. WISNIK, 1989. p. 236
} 
Na canção "Araçá Azul” estamos diante de um acorde que possui as duas características, ou seja, é um acorde maior e menor a um tempo, ao mesmo tempo luminoso e escuro. Ao colocar estas duas informações em uma mesma estrutura, mais do que apresentar oposições e ressaltar ambigüidades, Caetano está construindo um objeto complexo que ao mesmo tempo absorve e supera a oposição. O segundo acorde é produzido com o deslocamento de meio tom na terça maior (Sol\#). Temos então Mi, Lá, Sol e $\mathrm{Si}$, acorde menor com $11^{\mathrm{a}}$, absolutamente convencional.

A segunda parte é construída com dois acordes de A (Lá) com nona adicionada, acordes brilhantes, de sonoridade aberta, e o retorno para o primeiro acorde da canção. O primeiro acorde A tem a $11^{\mathrm{a}}$ aumentada, o que além de proporcionar um brilho ainda maior, é uma referência ao modo lídio, citando um fazer musical com sabor tipicamente nordestino. $^{2}$

Existe uma forte ligação entre a estrutura da letra e da harmonia nesta canção. O acorde híbrido se relaciona diretamente à descrição do objeto "Araçá Azul": este também é definido com uma conjunção de opostos: é "segredo" e "não é segredo", é "brinquedo" e "o nome mais belo do medo". Utilizando um interessante jogo de linguagem, o autor reafirma o mistério do objeto descrito ("é segredo") negando-o ("não é segredo"). Temos aqui também um objeto complexo, que assume ao mesmo tempo características eufóricas e disfóricas: é ao mesmo tempo lúdico e opressor, é secreto e revelado. Ele é a verdadeira reafirmação do mistério. Dois elementos discursivos sustentam o efeito de sentido de verdade dessa passagem: o uso da debreagem enunciva e o presente proverbial.

\footnotetext{
${ }^{2}$ Cf. a análise de "Épico", p. 127.
} 
É interessante como essa oposição se manifesta na voz do personagem instaurado pela enunciação: ao mesmo tempo em que há uma esperança em se libertar da opressão (manifestada em morte), há uma consciência de sua inevitabilidade (eu não vou morrer tão cedo). Há uma aceitação da dualidade deste objeto complexo, manifestada também na letra da canção.

Agora podem-se tirar conclusões mais precisas sobre o significado da expressão “Araçá Azul” (que aparece nos créditos dessa música como "Araçá Blue"). Por um lado, é um araçá deteriorado, que perdeu sua cor amarela viva e transformou-se num azul artificial, poluído. Sintetiza a própria trajetória do nordestino que, vivendo num ambiente hostil e inóspito, também sofreu transformações. No entanto, essa aparente deteriorização não se cristaliza em um valor disfórico, opondo-se diametralmente à euforia da pureza do estado original. A deteriorização gradual opera uma progressiva diluição da identidade, a tal ponto que o sujeito não é mais capaz de entrar em conjunção plena com esses valores primordiais, mas não profunda o suficiente para conjuntá-lo euforicamente com os valores novos. Essa dualidade o faz compreender a realidade em um sentido mais amplo, menos maniqueísta. Este fato faz com que esta faixa seja diferente de todas as outras. Não temos aqui um elemento opressor que force sua ligação com objetos disfóricos, e nem uma busca a elementos primordiais. Não existe sequer um conflito que possa separar elementos eufóricos e disfóricos, associando-os a uma outra oposição qualquer. A busca cessa com a impossibilidade dessa oposição primordial. O sujeito aceita o objeto complexo, e supera todas as outras oposições.

O andamento lento da canção é propício para a exteriorização do estado passional em que se encontra o sujeito. Notamos uma ampla tessitura, e uma predominância de saltos 
intervalares. A primeira parte da canção é composta por duas pequenas frases melódicas, a primeira com tonema descendente (que termina com o extremo grave) e a segunda ascendente (finalizando com o extremo agudo). Essa oposição é uma manifestação da contradição observada tanto no plano harmônico quanto no lingüístico. Após uma grande distensão, que repousa sobre o extremo grave e sobre a tônica da canção (é segredo), a melodia alcança o extremo agudo em apenas três notas, causando um súbito e dramático aumento da tensão (não é segredo). A canção prossegue com uma variação do primeiro tema (com fé em Deus eu não vou morrer tão cedo), repetida três vezes. Essa repetição de tonemas descendentes potencializa o poder de afirmação do verso cantado. Além disso, a extrema semelhança entre o tema inicial e o refrão retira todo o poder de surpresa deste. Estruturalmente, a música pouco evolui - a desaceleração aqui é total.

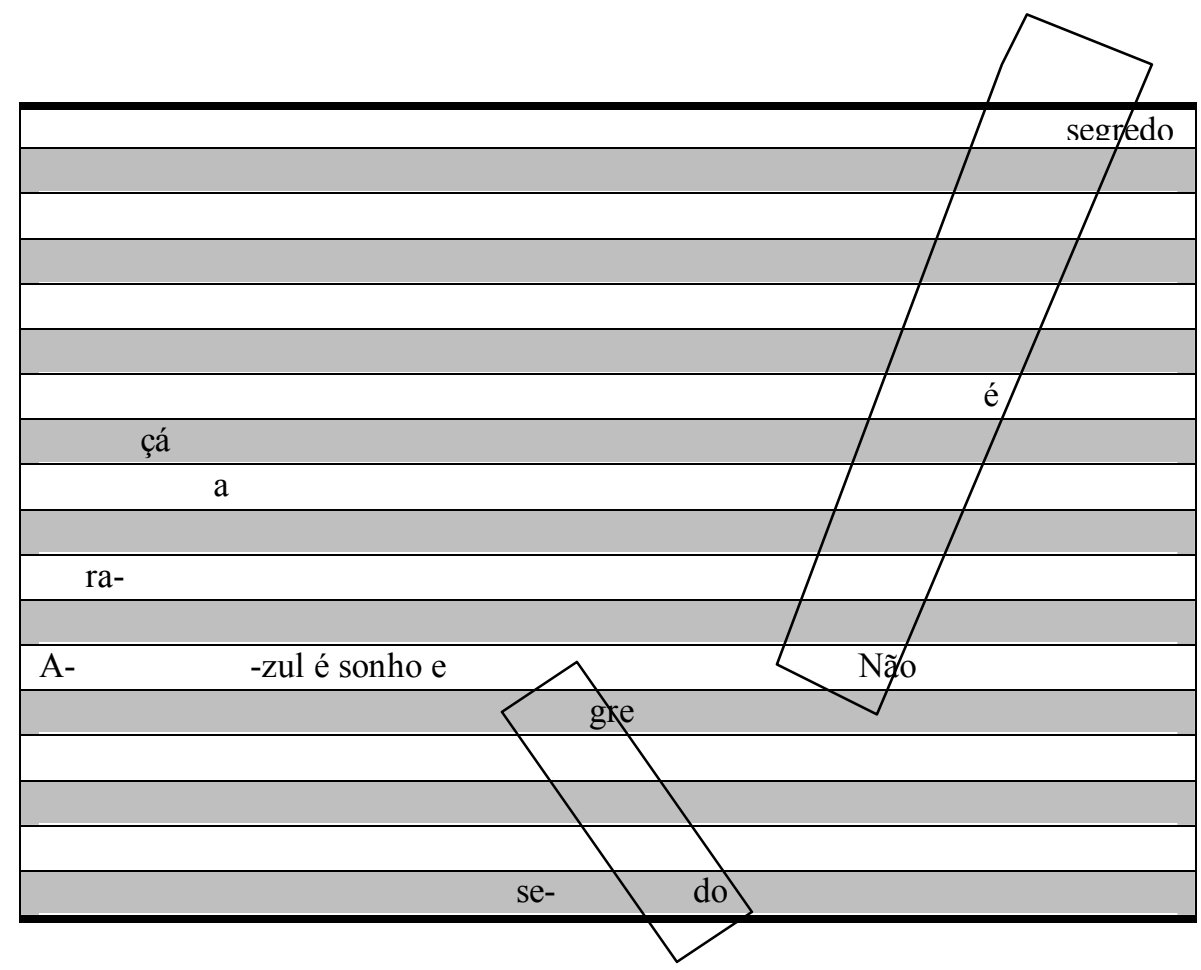



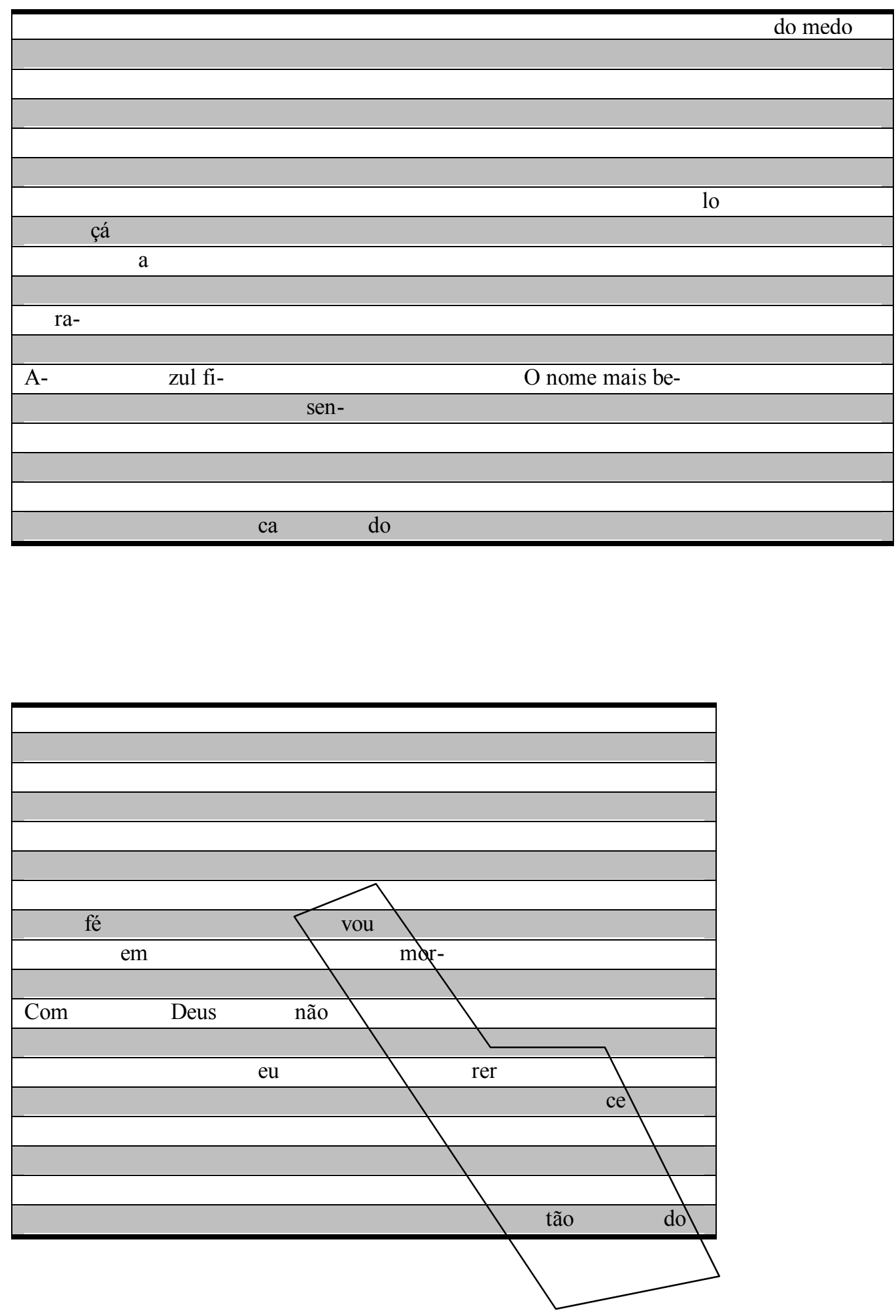


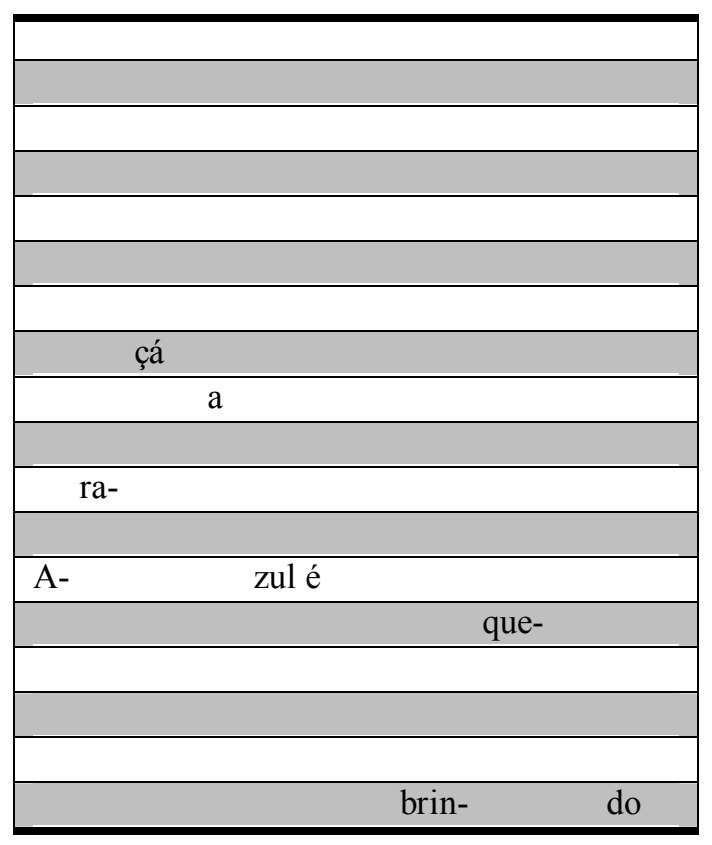




\section{Considerações finais}

Ao iniciar o presente trabalho, partimos da premissa de que o objeto escolhido para análise - o LP Araçá Azul - se organizaria em um todo coeso. Isso significaria admitir que o LP não seria apenas uma coletânea de canções, e que nele encontraríamos informações suficientes para alinhar em um mesmo eixo todo o material sonoro (as dez faixas) e visual (capa, contracapa e encartes). Esta hipótese foi amplamente confirmada pela reiteração constante de temas e procedimentos semióticos em diversos níveis de profundidade.

Podemos observar em toda a obra uma intensa e profunda discussão sobre as relações com os valores de origem, e a tensão decorrente do choque entre valores internos e externos. Essa discussão se manifesta não só do ponto de vista temático, descrito pela trajetória de sujeitos instaurados sobretudo pelas letras das canções, mas surge também na

forma de questionamentos estéticos que atingem toda a estrutura das composições. À medida que a discussão se aprofunda, o autor apresenta os impactos dessa tensão sobre a identidade, e de que maneira ela reage a esses impactos.

O próprio conceito de identidade é trabalhado de maneira muito ampla e dinâmica. Partindo daquilo que lhe é muito próximo, ou seja, os valores próprios da cultura do recôncavo baiano, Caetano propõe a construção da identidade sob o aspecto geográfico, étnico e lingüístico. Se em determinada passagem dois elementos estão em relação de oposição, como por exemplo o sertão e a cidade urbana, em outra eles estão juntos para construir a idéia de identidade nacional. Mais adiante, a identidade nacional pode dar lugar à identidade latino-americana, ou até mesmo pan-americana. Temos então uma sucessão de movimentos de oposição e de síntese, numa veloz recombinação de elementos: sempre que 
uma oposição promove uma ruptura, em um determinado nível, ela se reorganiza e realiza uma sutura, para a construção de uma nova oposição em outro nível. Se em algumas faixas podemos observar oposições maniqueístas, fica claro que no conjunto da obra prevalece uma intenção relativizadora.

Essa postura é confirmada com a presença constante de fatores como a fragmentação, a desestabilização, a ambigüidade e a indefinição. Em alguns momentos, estes são os temas centrais desenvolvidos pelo texto lingüístico. Em outros, são os procedimentos empregados no plano estético. A tensão manifestada pelo choque de valores do sujeito ecoa profundamente no plano estrutural do LP. Enquanto o sujeito opera sua busca de valores e a definição do seu /ser/, o mesmo acontece com forma e a estrutura da canção. A fragmentação progressiva do sujeito ao perder seus valores de origem é manifestada visual e sonoramente. À medida que ele questiona o sistema de valores ao qual está ligado, realiza-se uma desestabilização dos sistemas melódico, harmônico e lingüístico sobre os quais o texto é construído. A incorporação progressiva dos valores externos produz um verdadeiro desfile de gêneros: do samba de roda ao bolero, do repente ao rock. Ao invés de cristalizar uma tendência, Caetano prefere valorizar o acorde tenso produzido pela fricção dos opostos.

As dez faixas do LP podem ser reorganizadas em uma seqüência lógica que tem como pano de fundo a relação entre o sujeito e seus valores. Em "Viola, meu bem" temos um sujeito separado de seus valores de origem, e ligado a eles pelo sentimento de falta. Em "De conversa", o sujeito fragmentado busca um /saber/ acerca dos valores de origem (“quem temperou"). Em "Tu me acostumbraste", o sujeito não tem competência modal suficiente para buscar os valores. Em "Júlia/Moreno", temos a indefinição completa do 
/ser/. "Sugar cane fields forever" é a faixa mais complexa: nela convivem a aceitação dos valores externos, a reafirmação dos valores internos, a fragmentação, a desestabilização e a ambigüidade. Em "Gilberto misterioso", a desestabilização se manifesta como possibilidade. Em "De palavra em palavra", a reversão é apresentada como possibilidade. Em "Quero essa mulher assim mesmo", há a aceitação plena dos valores externos, manifestada como uma ruptura das regras vigentes. Em "Épico", há um enorme ganho de competência, e a apropriação do externo é o fato central na narrativa. A inversão de valores, antes manifestada como possibilidade, aqui se manifesta de maneira concreta. Finalmente, temos em "Araçá Azul” a superação da oposição interno vs externo, com a aceitação simultânea dos termos opostos.

A partir da análise, é fácil perceber que estamos diante de uma obra alinhada com a estética tropicalista. No entanto, existem nela marcas que a distanciam das outras produções tropicalistas realizadas durante o movimento. O fazer veridictório impresso em algumas passagens desvelam o hiato existente entre ela e o Tropicália - panis et circenses. Para que a instância do /saber/ possa se manifestar, faz-se necessária a interrupção do fluxo temporal. Em outras palavras, ao reavaliar a estética tropicalista, o autor inevitavelmente já se mostra um pouco distante dela. Algumas rupturas realizadas pelo tropicalismo surgem aqui em forma de sutura, na medida em que alguns elos são explicitados. A violência da explosão da década de 60 é aqui apresentada como uma atualização do modernismo antropofágico, sendo este por sua vez uma atualização da produção sousandradina.

Uma vez concluída a análise, acreditamos ter evidenciado e colocado em discussão os principais elementos utilizados na construção do sentido em Araçá Azul. Com isso, 
esperamos ter contribuído tanto para a expansão do conhecimento acerca do tema, como para as possibilidades analíticas de uma obra com esse perfil.

A originalidade tanto da forma quanto do conteúdo do material analisado sugere o desdobramento dos estudos em diversos segmentos. Seria interessante confrontar os dados aqui elencados com outra obra do movimento tropicalista, em um estudo comparativo, para posicioná-la melhor em relação ao movimento. Por outro lado, seria igualmente interessante avaliar sua importância no âmbito de toda a obra do compositor Caetano Veloso. Com isso, poderíamos determinar se o Araçá Azul é de fato uma manifestação intensa de elementos por ele trabalhados ao longo de sua carreira, ou se representa um fato isolado.

Três outras questões surgiram no decorrer de nossa análise, e que poderiam ser melhor investigadas. Uma delas incide sobre a viabilidade de se estabelecer as relações existentes entre a capa de um LP ou um CD e o material sonoro do mesmo. Com isso, seria possível precisar melhor de que maneira cada projeto gráfico se posiciona dentro do mercado fonográfico, já que ele atua ao mesmo tempo como parte de um todo artístico e como parte de uma estratégia de mar eting. A segunda questão surgiu ao analisar a faixa "Júlia/Moreno", vislumbrando a possibilidade de investigações sobre as relações entre música e poesia concreta, principalmente no que se refere à proposição de novos eixos de significação. Finalmente, constatamos a extrema necessidade de ampliação do modelo descritivo para que este possa dar conta dos fatos harmônicos em música popular. É necessário "semiotizar" as questões envolvidas no movimento harmônico e explorar a manifestação da categoria juntiva e de outras categorias semióticas em fenômenos como o empréstimo modal e a modulação. 


\section{Bibliografia}

ANDRADE, Mário de. Dicionário musical brasileiro. Belo Horizonte: Itatiaia, 1999.

BARROS, Diana Luz Pessoa. Teoria semiótica do texto. São Paulo: Ática, 1997.

. Teoria do discurso: fundamentos semióticos. São Paulo: Atual, 1988.

CALADO, Carlos. Tropicália: a história de uma revolução musical. São Paulo: Editora 34, 1997.

CAMPOS, Augusto de. O balanço da bossa e outras bossas. São Paulo: Perspectiva, 1998.

CAMPOS, Augusto de; CAMPOS, Haroldo de. Souzândrade. São Paulo: Agir, 1979.

. Revisão de Sousândrade. 2. ed. Rio de Janeiro: Nova Fronteira, 1982.

CAMPOS, Augusto de; CAMPOS, Haroldo de; PIGNATARI, Décio. Teoria da Poesia Concreta. São Paulo: Brasiliense, 1965.

CHEDIAK, Almir. Harmonia e Improvisação. 2 vols. Rio de Janeiro: Lumiar, 1986. . Songboo Caetano Veloso. 2 vols. Rio de Janeiro: Lumiar, 1989.

FAVARETTO, Celso. Tropicália: Alegoria, alegria. 2. ed. rev. São Paulo: Ateliê Editorial, 1996.

FIORIN, José Luiz. As astúcias da enunciação. São Paulo: Ática, 1999. . Elementos de análise do discurso. São Paulo: Contexto, 2000.

FONSECA, Heber. Caetano, esse cara. Rio de Janeiro: Revan, 1993.

GIL, Gilberto. Todas as letras [Organizado por Carlos Rennó]. São Paulo: Companhia das letras, 1996.

GREIMAS, Algirdas Julien. Sémantique structurale. Paris: Larousse, 1966. . Du sens I: éssais sémiotiques. Paris: Seuil, 1970 
. Du sens II: éssais sémiotiques. Paris: Seuil, 1983

GREIMAS, Algirdas Julien; COURTES, Joseph. Sémiotique. Dictionnaire raisonné de la théorie du langage. Paris: Hachette, 1986.

GREIMAS, Algirdas Julien; FONTANILLE, Jaques Semiótica das paixões. São Paulo: Ática, 1994.

HJELMSLEV, Louis. Prolegômenos a uma teoria da linguagem. São Paulo,: Perpesctiva, 1975.

LOBO, Luiza. Épica e modernidade em Souzândrade. São Paulo: Presença/Edusp, 1986. . Tradição e ruptura: O Guesa de Sousândrade. São Luís: Sioge, 1979.

LOPES, Paulo Eduardo. A desinvenção do som. Campinas: Pontes, 1999

MEDAGLIA, Júlio. Música Impopular. São Paulo: Global, 1988.

PERSICHETTI, Vicenti. Twentieth century harmony. New York: W.W Norton \& company Inc, 1961.

RISÉRIO, Antonio. Avant-garde na Bahia. São Paulo: Instituto Lina Bo e P.M. Bardi, 1995.

SANT ANNA, Affonso R., Música popular e Moderna poesia brasileira.s/d.

SAUSSURE, Ferdinand. Curso de Ling ística Geral. São Paulo: Cultrix, 1997.

SOUZ NDRADE, Joaquim de, O inferno de Wall Street, Paris, Éditions Seghers, 1981. . Inéditos. Maranhão: Departamento de Cultura do Estado, 1979

TATIT, Luiz Augusto de Moraes. O cancionista: composição de canções no Brasil. São Paulo: Edusp, 1996. . Musicando a semiótica. Editora Anablume: 1998. . Semiótica da canção - melodia e letra. São Paulo: Escuta, 1994. 
. Tempo e tensividade na análise da canção. In: Cadernos de estudo de análise musical 3. São Paulo, 1992. pp.27-84.

TH RLEMAN, Félix. Trois peintures de Paul lee: essai d'analyse sémiotique. 1979. 154

p. Tese de doutoramento - École des hautes études en sciences sociales.

VELOSO, Caetano. Verdade Tropical. São Paulo: Companhia das Letras, 1997 . Alegria, alegria. [Organizado por Wally Salomão]. Rio de Janeiro: Pedra Q

Ronca, s.d.

ZILBERBERG, Claude. Présence de W lfflin. In: Nouveaux actes sémiotiques. Limoges, Trames, vol. 23/24, 1992.

. Rélativité du Rithme. In: Protée - Théories et pratiques sémiotiques.

Département des arts et lettres de l'université de Quebec à Chicontini. Vol. 18, n.1, 1990. pp. 37-46.

ZILBERBERG, Claude; FONTANILLE, Jaques. Valence / Valeur. In: Nouveaux actes sémiotiques. Limoges, Pulim, vol. 46/47, 1996.

WISNIK, José Miguel. O som e o sentido. São Paulo: Companhia das Letras - Círculo do Livro, 1989. 


\section{Glossário}

Acorde: sobreposição de três ou mais notas. Sua estrutura de base pode ser a tríade ou a tétrade.

Ad libitum: ritmo livre.

Altura: é a propriedade do som determinada pela freqüência de vibração da onda sonora.

Andamento: é a velocidade do pulso, expressa em batimentos por minuto.

Atonal: sistema que dissolve o jogo de atratividades do sistema tonal. A harmonia tonal não tem um centro de repouso harmônico.

Bemol: sinal de alteração que abaixa a nota em um semitom.

Cabeça do compasso: momento de ataque do primeiro tempo de um compasso.

Cadência: seqüência de acordes de funções diferentes.

Cadência deceptiva: situação em que a tensão do acorde dominante não resolve no acorde de tônica, gerando quebra de expectativa.

Campo harmônico: conjunto de acordes formados por uma mesma escala.

Cifra: conjunto de letras e números utilizado para representar os acordes. Às notas La, Si, Dó, Ré, Mi, Fá e Sol são atribuídas as letras A, B, C, D, E, F e G, respectivamente.

Coma: menor intervalo que o ouvido humano consegue distinguir.

Dinâmica: variação de intensidade e andamento

Empréstimo modal: situação em que um acorde de uma tonalidade menor surge em uma tonalidade maior ou vice-versa. 
Escala: “A escala é um estoque simultâneo de intervalos, unidades distintivas que serão combinadas para formar sucessões melódicas. A escala é uma reserva mínima de notas, enquanto as melodias são combinações que atualizam discursivamente as possibilidades intervalares reunidas na escala como pura virtualidade."1

Escala cromática: seqüência de notas em intervalo de semitom, sendo que a última é a repetição da primeira uma oitava acima.

Escalas homônimas: escalas diferentes construídas a partir da mesma nota. Ex: Dó maior e Dó menor.

Escalas relativas: Diz-se das escalas maiores e menores construídas com as mesmas notas. Ex: Dó maior e Lá menor. A escala menor inicia no sexto grau da escala maior.

Função harmônica: sensação auditiva que determinado acorde produz quando tocado. As principais funções são tônica, dominante e subdominante. A função não depende exclusivamente da estrutura interna do acorde, mas também da relação que ele estabelece com outros na seqüência harmônica.

Harmonia: em música, o termo harmonia tanto pode designar o estudo da disposição e a condução das notas nos acordes como o estudo do encadeamento de acordes em seqüência.

Intervalo: é a distância entre as notas, medidas em tons. Sua classificação é feita a partir de um elemento quantitativo (que define a sua posição na escala: segunda, terça, quarta, etc...) e outro qualitativo, que precisa a distância da nota em relação à fundamental (segunda menor, terça maior, quarta aumentada, etc...).

Inversão: situação em que a fundamental do acorde não é a nota mais grave do mesmo.

\footnotetext{
${ }^{1}$ WISNIK, 1989.p. 71
} 
Intensidade: propriedade do som relacionada à amplitude da onda sonora.

Melodia: seqüência de notas que define um tema.

Modal: sistema no qual o centro de repouso harmônico é constantemente reiterado ao longo da execução. Ele é normalmente melódico e polifônico. Presente em diversas manifestações da música oriental até os dias de hoje, o melhor exemplo do modalismo na música ocidental é o canto gregoriano.

Modulação: mudança do centro tonal no decorrer de uma seqüência harmônica.

Polifonia: exibição simultânea de duas ou mais linhas melódicas.

Portamento: transição suave entre uma nota e outra.

Quadratura: seqüência formada por quatro compassos.

Ritmo: Em uma acepção mais ampla, ritmo é uma palavra complexa que sintetiza todos os elementos musicais diretamente relacionados com o tempo. Isto engloba a duração individual de cada nota, a relação de fase e defasagem entre um grupo de notas, o ponto de ataque de cada nota, a organização hierárquica (acento) de cada elemento, além da velocidade do pulso principal (andamento).

Ritmo harmônico: esquema rítmico da base harmônica.

Ponto de ataque: momento exato em que ocorre determinado fenômeno auditivo.

Posição fundamental: situação na qual a fundamental é a nota mais grave de um acorde.

Semitom: menor intervalo possível entre duas notas no sistema temperado, sobre o qual é baseado o tonalismo.

Sustenido: sinal de alteração que aumenta a nota em um semitom.

Tessitura: intervalo compreendido entre a nota mais grave e a mais aguda de um trecho musical. 
Tétrade: estrutura de base do acorde formada por quatro notas em intervalos de terça.

Timbre: propriedade do som relacionada à forma da onda sonora. Cada instrumento produz uma onda sonora de forma diferente. Por isso mesmo, costuma-se falar "timbre de violão" para se referir ao tipo de som produzido pelo mesmo.

Tonal: sistema que estabelece um centro de repouso harmônico com o qual todos os outros acordes dialogam.

Tonalidade homônima: tonalidade estabelecida pela escala homônima.

Tríade: estrutura de base do acorde formada por três notas em intervalos de terça. 
8. Anexo

8.1. Capa

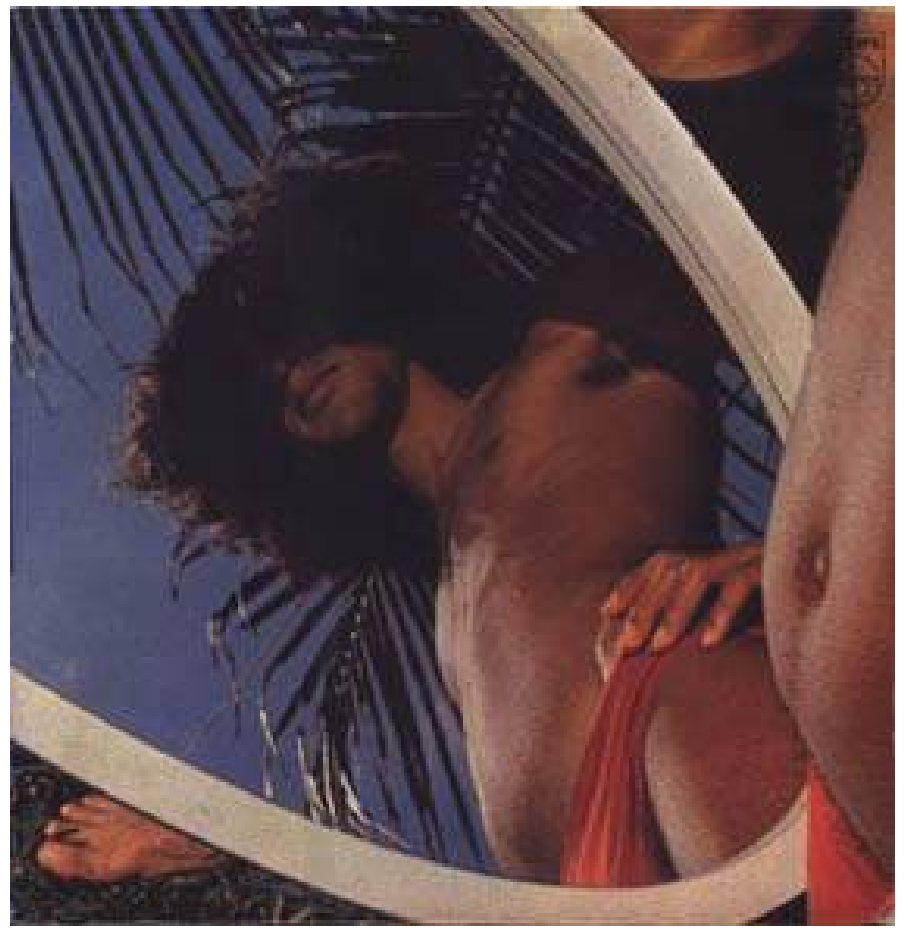

8.2. Contracapa

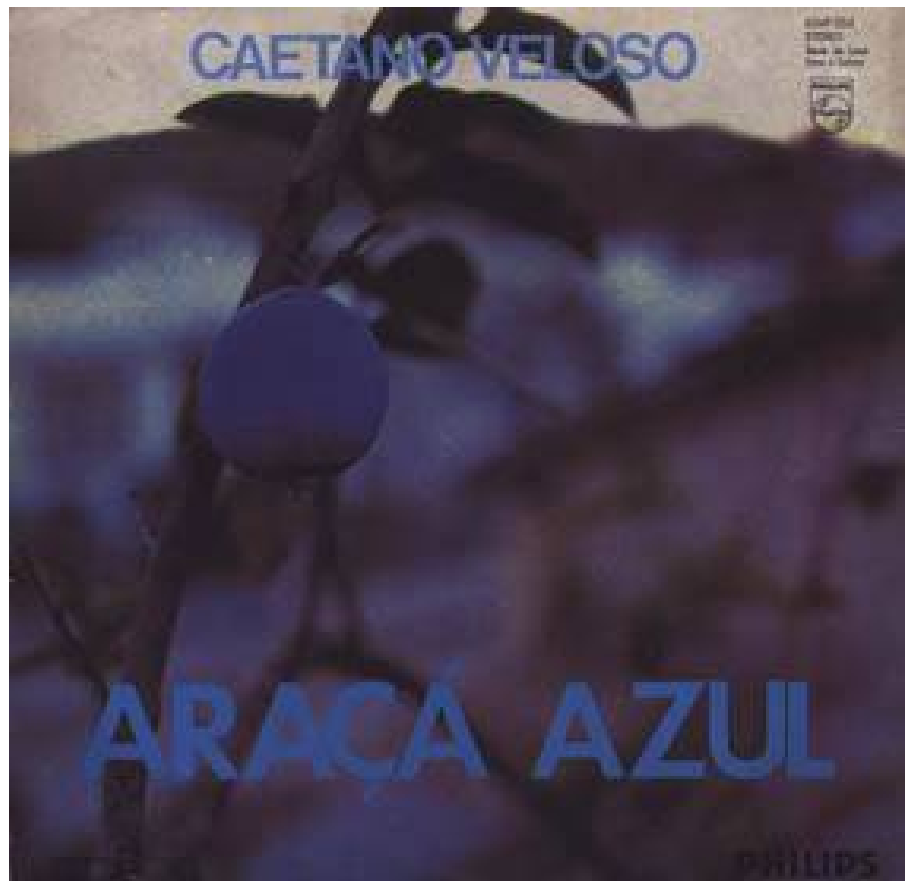


8.3. Encarte Interno

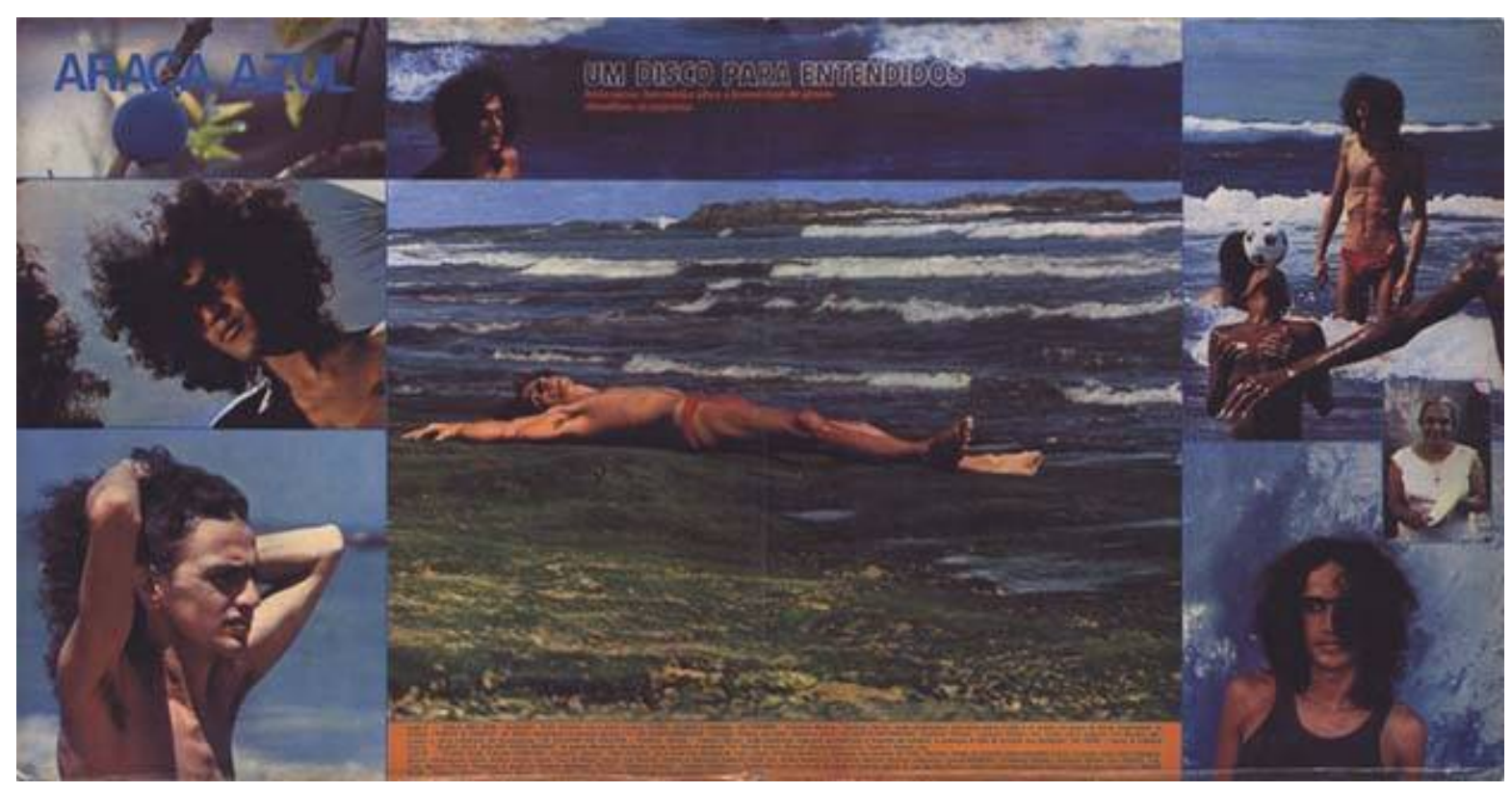

